\title{
Enhancement of photocatalytic activity of titanium dioxide-based photocatalysts
}

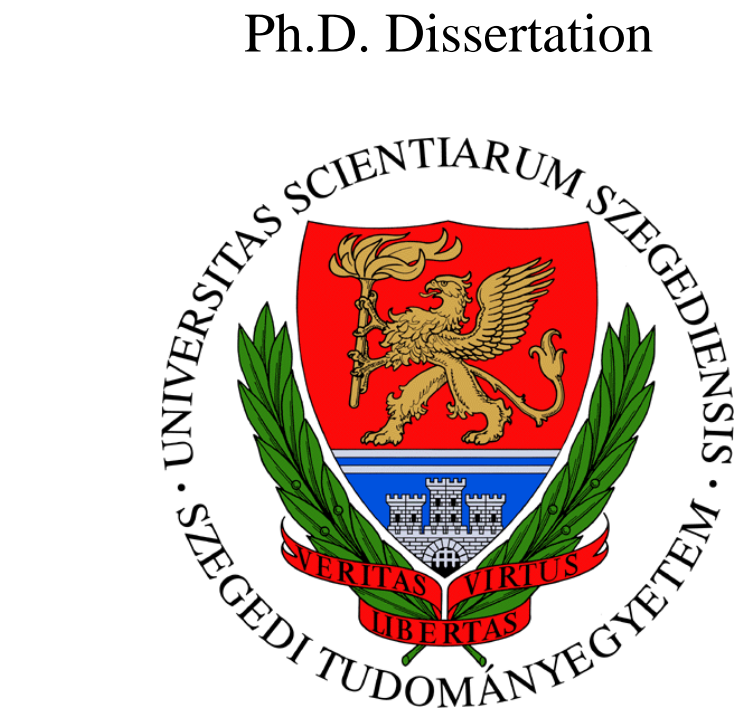

\section{Tamás Zsolt Gyulavári}

Supervisor:

Prof. Klára Hernádi

\begin{abstract}
Doctoral School of Chemistry
Department of Applied and Environmental Chemistry, Faculty of Science and Informatics, University of Szeged
\end{abstract}

Szeged

2020 


\section{Table of contents}

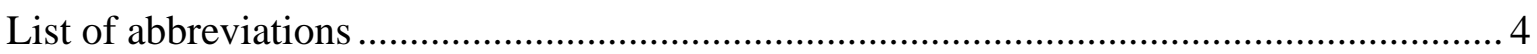

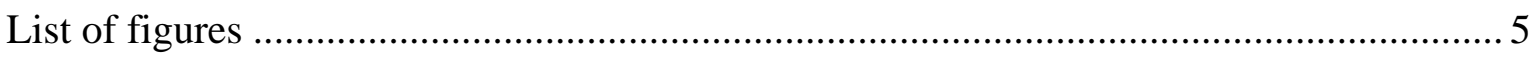

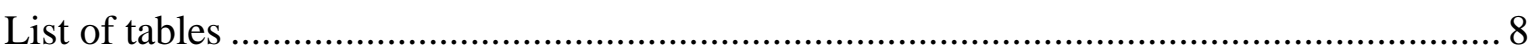

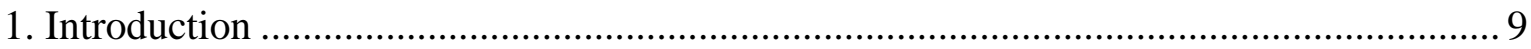

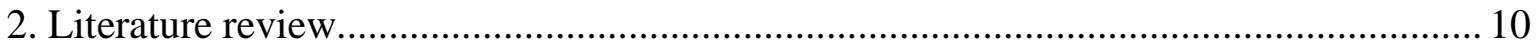

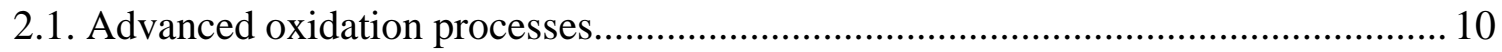

2.2. Heterogeneous photocatalysis and its applicability spectra ................................. 10

2.3. Titanium dioxide and its photocatalytic applications .......................................... 14

2.4. Strategies for improving the photocatalytic activity of titanium dioxide................. 19

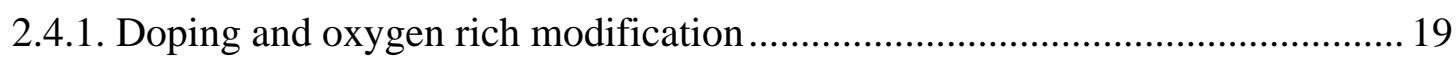

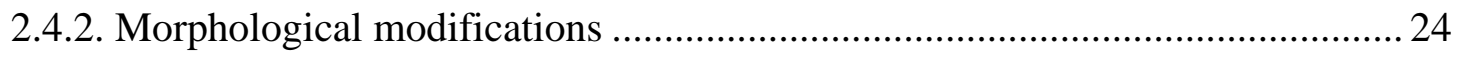

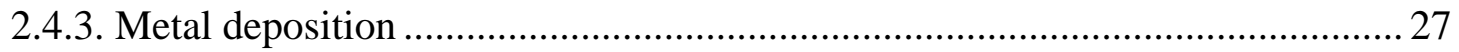

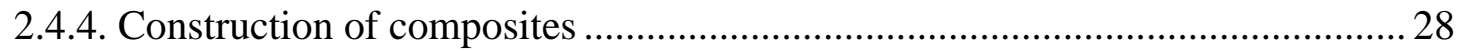



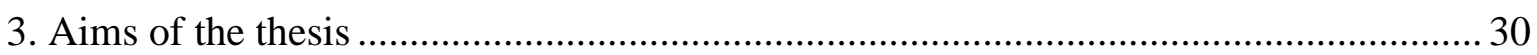

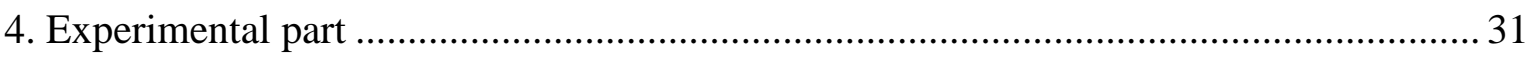

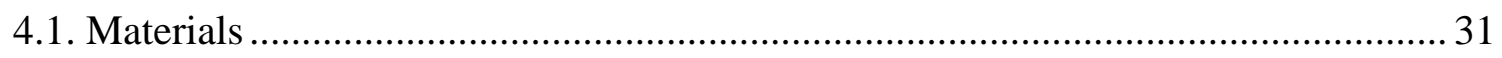

4.2. Syntheses of the titanium dioxide-based photocatalysts ......................................... 31

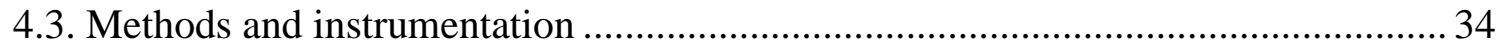

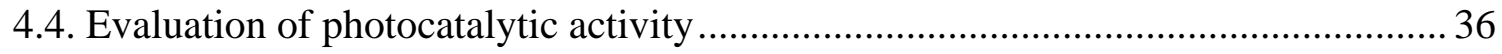

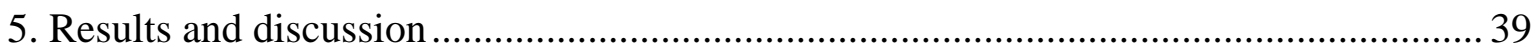

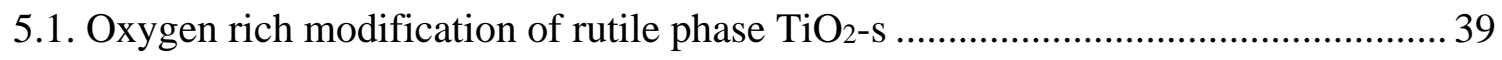

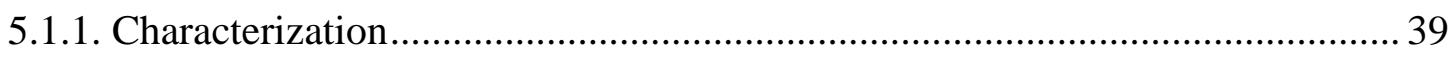

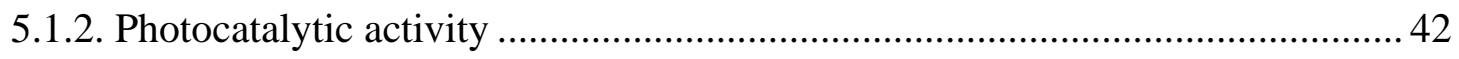

5.1.3. Further characterization and establishing connection between the results of morpho-structural characterization and photocatalytic activity ................................ 43

5.2. Oxygen rich modification of amorphous and anatase phase $\mathrm{TiO}_{2}-\mathrm{S}$......................... 49

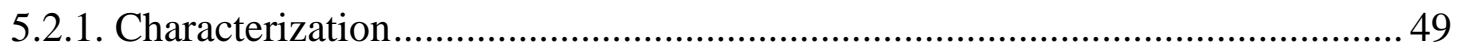

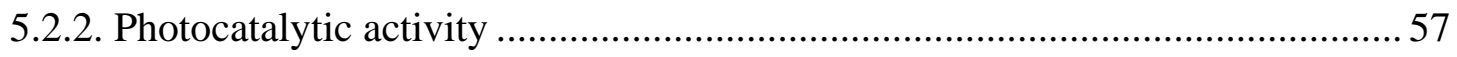

5.2.3. Further characterization and establishing connection between the results of morpho-structural characterization and photocatalytic activity ............................... 59 


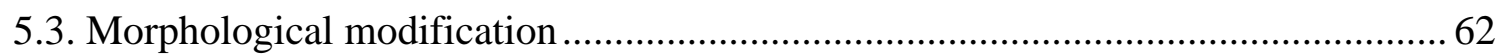

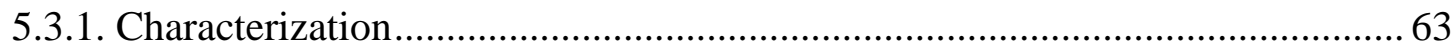

5.3.1.1. Characterization of carbon sphere templates............................................. 63

5.3.1.2. Characterization of $\mathrm{TiO}_{2}-\mathrm{CS}$ composites and $\mathrm{TiO}_{2}$ hollow structures ....... 69

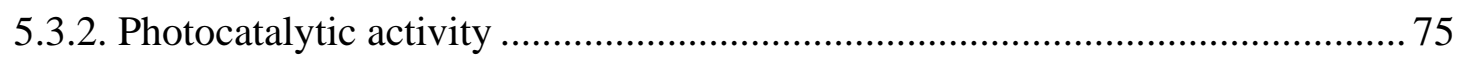

5.3.3. Further characterization and establishing connection between the results of morpho-structural characterization and photocatalytic activity ................................ 77

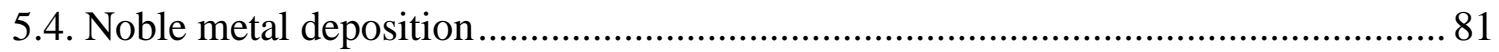

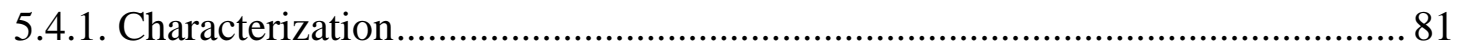

5.4.1.1. Characterization of $\mathrm{TiO}_{2}$ hollow spheres.................................................. 81

5.4.1.2. Further characterization of reference $\mathrm{TiO}_{2}-\mathrm{s}$ and $\mathrm{TiO}_{2}-\mathrm{HSs}$ modified with

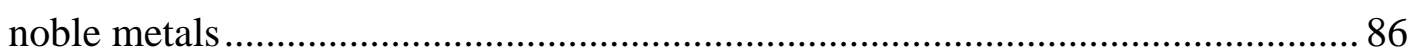

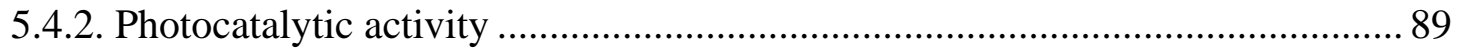

5.4.3. Establishing connection between the results of morpho-structural characterization and photocatalytic activity ............................................................... 90

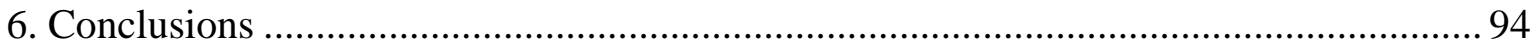

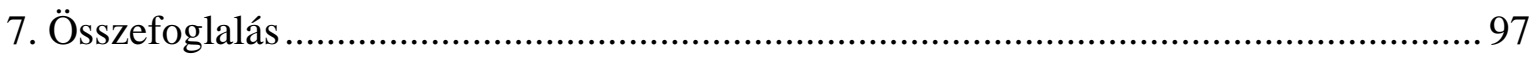

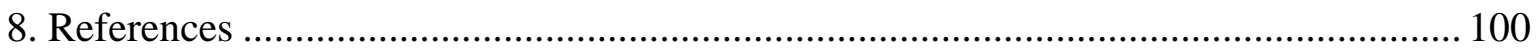

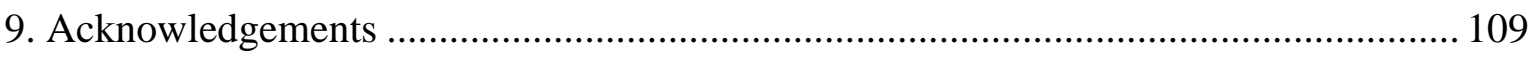

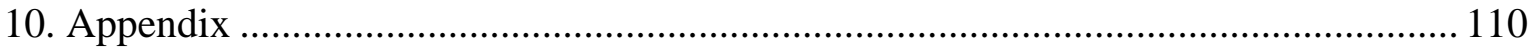




\section{List of abbreviations}

AOP $\quad$ Advanced $\underline{\text { Oxidation }}$ Process

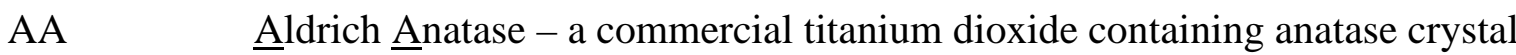
phase

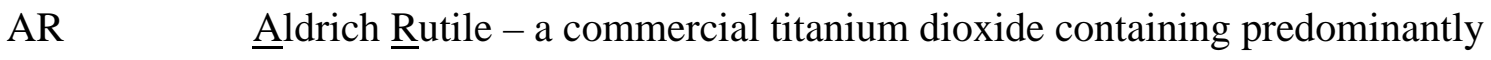
rutile phase

BET Theory named after Brunauer-Emmett-Teller used to calculate specific surface area

CSs $\quad$ Carbon $\underline{\text { Spheres }}$

CB $\quad$ Conduction $\underline{B}$ and

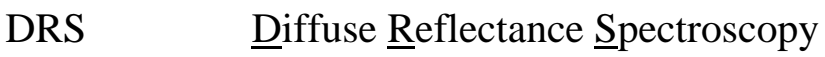

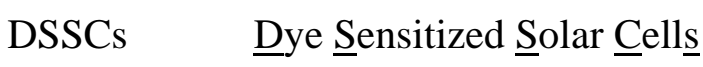

DTG Differential Thermogravimetry

FT-IR $\quad$ Fourier Transformation Infrared Spectroscopy

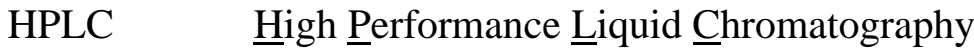

HSs $\quad$ Hollow $\underline{\text { Spheres }}$

MQ Ultrapure Millipore $\underline{\text { Milli-Q }}$ water

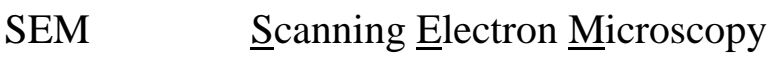

TEM $\quad$ Transmission Electron Microscopy

$\mathrm{TiO}_{2}-\mathrm{S} \quad \underline{T}$ Titanium Dioxides

P25 Commercial $\mathrm{TiO}_{2}$ frequently used as reference, containing $~ 90 \%$ anatase and $\sim 10 \%$ rutile

Rutile-H2 Home-made rutile phase $\mathrm{TiO}_{2}$ synthesized applying $\mathrm{n}_{\mathrm{TiO}_{2}}: \mathrm{n}_{\underline{H}_{2} \mathrm{O}_{2}}=1: \underline{2}$ containing peroxo groups, used frequently as reference or starting material for subsequent syntheses; abbreviated simply as 'H2' in some cases

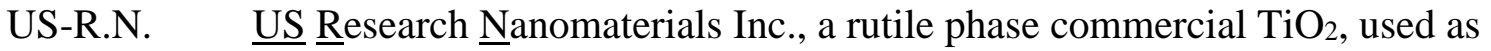
reference

UV $\quad$ Ultraviolet light

VB ㅁalence band

Vis Visible light

XPS $\quad \underline{X}$-Ray $\underline{\text { Photoelectron } \underline{S} p e c t r o s c o p y}$

XRD $\quad \underline{X}$-Ray $\underline{\text { Diffractometry }}$ 


\section{List of figures}

Figure 1 Band structure of semiconductors.

Figure 2 Crystalline structures of titanium dioxide: (a) anatase, (b) rutile, (c) brookite.

Figure 3 Possible intermediates of phenol during its photocatalytic oxidation.

Figure 4 Composition of the solar spectrum that reaches the Earth's surface.

Figure 5 Proposed structure of peroxo titanium complex.

Figure 6 Proposed mechanism of the photocatalytic degradation of methanol via peroxo titania.

Figure 7 Schematic representation of the enhanced visible light harvesting of hollow spherical $\mathrm{TiO}_{2}$.

Figure 8 Reactor settings equipped with visible light-emitting lamps (a; by using $\mathrm{NaNO}_{2}$ cut-off solution), UV lamps (b) and their corresponding emission spectra (c, d).

Figure 9 X-ray diffraction patterns of the investigated rutile phase $\mathrm{TiO}_{2}-\mathrm{S}$.

Figure 10 DR spectra of the investigated $\mathrm{TiO}_{2}$-s (top) and their first order derivatives (bottom).

Figure 11 FT-IR spectra of the investigated $\mathrm{TiO}_{2}-\mathrm{s}$.

Figure 12 Decay curves of phenol under visible light irradiation. The reusability of Rutile-H2 $\mathrm{TiO}_{2}$ is represented in the inset.

Figure 13 High-resolution O1s XPS spectra of Rutile-O, Rutile-H2, Rutile-H3 and reference AR. Samples Rutile-H2 and AR were re-used three times to investigate peroxo group stability.

Figure 14 X-ray diffraction patterns of the investigated home-made (a) and reference (b) $\mathrm{TiO}_{2}-\mathrm{s}$.

Figure 15 DR spectra of the investigated $\mathrm{TiO}_{2}-\mathrm{s}$.

Figure 16 First order derivative DR spectra of the investigated $\mathrm{TiO}_{2}-\mathrm{s}$.

Figure 17 FT-IR spectra of the home-made Amorphous-H2, Anatase-H2 and Rutile$\mathrm{H} 2 \mathrm{TiO}_{2}$-S.

Figure 18 Raman spectra of home-made Amorphous-H2, Anatase-H2 and reference AA titania. 
Figure 19 High-resolution O1s and Ti2p XPS spectra of Amorphous-H2.

Figure 20 Decay curves of phenol under visible light irradiation.

Figure 21 The effect of hydrothermal treatment duration on the yield of the carbon spheres.

Figure 22 Morphology of carbon spheres prepared at different synthesis times (indicated in the upper left corner of the SEM pictures). Particle size distributions of CSs are shown in the histograms right to the corresponding SEM micrographs.

Figure 23 The effect of $\mathrm{pH}$ on the morphology of the prepared carbon spheres.

Figure 24 X-ray diffraction pattern (a), Raman (b), FT-IR spectra (c) and TG curve (d) of CS-12-12.

Figure 25 X-ray diffraction patterns of the home-made predominantly anatase phase $\mathrm{TiO}_{2}$-s and P25 (a), and our home-made rutile phase $\mathrm{TiO}_{2}-\mathrm{s}$ (b).

Figure 26 SEM micrographs of the H2_HS_5 (a) and H2_HS_6 (b) samples.

Figure 27 DR spectra of the investigated $\mathrm{TiO}_{2}-\mathrm{s}$.

Figure 28 IR spectra of the investigated $\mathrm{TiO}_{2}-\mathrm{s}$.

Figure 29 Photocatalytic decomposition of phenol solutions under visible light irradiation $\left(\mathrm{C}_{\text {phenol }}=0.1 \mathrm{mM}, \mathrm{C}_{\mathrm{TiO}_{2}}=1.0 \mathrm{~g} \cdot \mathrm{L}^{-1}\right)$.

Figure 30 The core XPS spectra of samples H2_HS_5 (a - Ti2p; b - O1s; c - C1s), H2_HS_2 (d - C1s) and H2_HS_6 (e - C1s) pointing out the influence of the calcination and/or the quality of the carbon spheres on the surface chemistry of the titania hollow spheres.

Figure 31 SEM micrographs of samples $\mathrm{TiO}_{2} \_\mathrm{HS}^{\mathrm{Ac}} 500$ (a), $\mathrm{TiO}_{2} \mathrm{HS}^{\mathrm{EtOH}_{500}}$ (b), $\mathrm{TiO}_{2} \mathrm{HS}^{\mathrm{Ac}} 800$ (c) $\mathrm{TiO}_{2} \mathrm{HS}^{\mathrm{EtOH}} 800$ (d) and their corresponding TEM figures (e-h, respectively).

Figure $32 \quad \mathrm{X}$-ray diffraction patterns of the investigated titania.

Figure 33 SEM (a) and TEM (b) images of reference non-hollow sample $\mathrm{TiO}_{2}$ no__HS ${ }^{\mathrm{Ac}}{ }_{500}$.

Figure 34 TEM images of samples $\mathrm{TiO}_{2} \mathrm{HS}^{\mathrm{Ac}}{ }_{500}-\mathrm{Au}(\mathrm{a}, \mathrm{b})$ and $\mathrm{TiO}_{2} \mathrm{HS}^{\mathrm{Ac}}{ }_{500}-\mathrm{Pt}(\mathrm{c}, \mathrm{d})$.

Figure 35 First order derivative DR spectra of the as-prepared photocatalysts.

Figure 36 FT-IR spectra of the investigated photocatalysts.

Figure 37 Photocatalytic activity of the investigated photocatalysts under UV light irradiation. 
Figure 38 Comparison of the ratio of $\mathrm{TiO}_{2}-\mathrm{HSs}$ with enhanced light trapping properties to the observed amount of degraded phenol model pollutant under UV light irradiation by the end of the 240-min-long experiments.

Appendix 1 IR spectra of carbon spheres purified with increasing amounts of acetone (CS_1 $<$ CS_2 $<$ CS_3, respectively) by membrane filtration.

Appendix 2 Comparison of $\mathrm{TiO}_{2}-\mathrm{CS}$ composite and $\mathrm{TiO}_{2}-\mathrm{HS}$ via XRD (a), IR (b) measurements, phenol degradation (c) under visible light irradiation and SEM micrographs before (d) and after (e) calcination.

Appendix 3 SEM micrographs of samples H2_CS_1-4 and H2_HS_1-4.

Appendix 4 XRD diffractograms of H2_HS_5 $\mathrm{TiO}_{2}$ before and after the 3 consecutive phenol degradation tests (a) and SEM micrographs of H2_HS_5 before (b) and after (c) the 3 consecutive phenol degradation tests (H2_HS_5_re).

Appendix 5 Diameter size distributions of the $\mathrm{TiO}_{2}-\mathrm{HSs}$.

Appendix 6 Photocatalytic activity of the investigated photocatalysts under visible light irradiation $(\mathrm{t}=240 \mathrm{~min})$. 


\section{List of tables}

Table 1 Phase composition and the average primer particle sizes of the investigated $\mathrm{TiO}_{2}-\mathrm{s}$.

Table 2 The identified oxygen-containing species' concentration in the investigated samples.

Table 3 Phase composition, average primer particle sizes, band gaps and specific surface areas of the investigated $\mathrm{TiO}_{2}$-s.

Table 4 Comparison of samples Amorphous-, Anatase-, Rutile-H2 and AR in terms of crystallinity, photocatalytic activity and peroxo group amount (from the total oxygen content) considering the phenol degradation experiments.

Table 5 Applied synthesis parameters during the preparation of $\mathrm{TiO}_{2}-\mathrm{CS}$ composites and HSs (*: no HSs; **: moderate quality HSs; ***: good quality HSs).

Table 6 Phase composition, average primary particle sizes, band gaps, and specific surface areas of the investigated $\mathrm{TiO}_{2}$-s.

Table $7 \quad$ Crystal phase compositions, diameters (median), circularities and specific surface areas of the $\mathrm{TiO}_{2}-\mathrm{HSs}$ samples. 


\section{Introduction}

A reasonable way to begin my Ph.D. Dissertation is to highlight the importance of environmental protection. The Industrial Revolution was a major turning point in Earth's ecology and in the relationship between humans and their environment. The benefits of accelerated human development, improved health and life longevity, public health, energy usage and sanitation came at a cost though, and their full impact on the environment and natural resources was only realized much later. The awakening to the implications of unsustainable growth, the limited nature of natural resources and irreversible damage to the environment resulted in the change of attitude; the need to preserve the environment became apparent.

Among the problems to be solved, water purification and wastewater treatment are of utmost importance. A significant proportion of water pollutants can be efficiently eliminated by conventional water treatment methods; however, there are numerous pollutants which are biologically and/or chemically resistant, toxic and for their degradation alternative methods are required. Advanced oxidation processes (AOPs) are suitable alternative methods showing great potential to be used in water treatment applications and a subdiscipline of them is heterogeneous photocatalysis.

The potential of heterogeneous photocatalysis is that it enables the utilization of sunlight - an alternative green energy source - for the excitation of a semiconductor photocatalyst, on which the method is based on, enabling the development of truly environmentally friendly water treatment systems. The method is non-selective, due to the formation of reactive free radicals, which can be utilized to degrade a wide range of organic contaminants in the water. By the end of the treatment even complete mineralization can be achieved resulting in harmless end products such as water, carbon dioxide and inorganic ions. However, it is important to highlight that at the present time the efficiency of heterogeneous photocatalysis is inferior to ordinary water treatment methods in most cases, thus for its practical application it is imperative to enhance the photocatalytic activity of the semiconductors.

In my Ph.D. Dissertation I investigated some possibilities and their limitations in the case of titanium dioxide $\left(\mathrm{TiO}_{2}\right)$ based photocatalysts. It is worth mentioning that the characteristics and effectiveness of photocatalysts are dependent on a vast number of parameters and my aim was to explore these connections to the best of my knowledge. 


\section{Literature review}

\subsection{Advanced oxidation processes}

The expression 'advanced oxidation processes' (AOPs) is a collective term for methods which aim to degrade pollutants of the given medium through reactions with radicals. Applying these processes is practicable when there is no suitable microbiological or other method available to degrade organic pollutants. The common characteristics of AOPs that they are commenced by the activation of either the oxygen or pollutant, which then interact with each other. During these processes reactive free radicals form, which then interact with the pollutant, causing the possible formation of additional free radicals. Through peroxides and peroxy radicals the complete degradation (mineralization) of the pollutants can take place resulting in harmless end products like $\mathrm{H}_{2} \mathrm{O}$ and $\mathrm{CO}_{2}$ and inorganic ions. The formation of free radicals can be initiated by radiolysis or by chemical, photochemical and sonochemical means. For water treatment purposes the AOPs can be categorized as follows:

1. Methods based on the application of different oxidants (e.g. ozone, hydrogen peroxide);

2. Processes based on radiolysis;

3. Processes based on ultraviolet photolysis or high energy vacuum ultraviolet (VUV) photolysis;

4. Methods based on heterogeneous photocatalysis, which processes occur on the surface of illuminated photocatalysts (semiconductors).

In my Ph.D. Dissertation emphasis was put on studying heterogeneous photocatalytic processes.

\subsection{Heterogeneous photocatalysis and its applicability spectra}

A heterogeneous photocatalytic process occurs in multiphase systems in the concurrent presence of light and photocatalyst, which can lead to the acceleration of a chemical reaction. The discovery of its potential dates to the mid-1900s; however, when Fujishima and Honda managed to split water using the energy of light in 1972, did the 
interest in it grow rapidly partly due to the oil crisis of 1973 [1]. In the last nearly half century thousands of research articles were published regarding this topic. The potential of the method not only lies in the possibility to transform the energy of light into chemical energy, but to use UV, visible or even solar light for the excitation of the photocatalysts, enabling their utilization in an environmentally friendly way for water treatment purposes.

Heterogeneous photocatalysis is based on the application of the so-called photocatalysts, which are solid semiconductor materials, whose conductivity changes based on environmental conditions. The function of semiconductors and their difference from conductors and insulators can be described as follows. In a single atom the electrons can only occupy specific energy levels. When multiple atoms bond, the electrons are shared between them, and since the atoms are now interacting, their energy level shifts around. The individual energy levels of numerous atoms - which build up the solids and interact with each other - 'smear' into energy bands. The lower band (with lower energy) is called valence band (VB), the higher band is the conduction band (CB) and the energy gap between them is called band gap. In the ground state of the atoms all electrons are located in the valence band, since their numbers are just enough to populate the energy levels of this band. For a material to conduct, the electrons from the valence band must be able to jump to the conduction band (resulting in the material entering into the so-called excited state). The spacing of these energy levels determines whether the material is a conductor, insulator, or a semiconductor. In the case of conductors, the bands overlap with each other, so the electrons can easily move to the higher energy levels and this results in the spontaneous occurrence and termination of the excited state. When the energy difference between the two bands are too high the current cannot flow, since the electrons cannot jump from the lower band to the upper one; these materials are the insulators. Semiconductors fall in the middle, since they have a small enough band gap so electrons can jump from the valence band into the conduction band provided sufficient amount of energy (equal or greater than the band gap) is transferred to it (either in the form of electromagnetic radiation, heat or electric current). When this happens, positively charged vacancies, the so-called holes $\left(\mathrm{h}^{+}\right)$remain at the place of the electrons, which can take part in charge transfer reactions, similarly to electrons (Fig. 1). 




Figure 1 Band structure of semiconductors.

If there are electron donors (D) and acceptors (A) on the surface of the excited photocatalyst, that can donate or accept electrons in such way, that the energy of the band gap is equal or greater than the activation energy of both reactions, then this can result in the initiation of a series of chemical reactions. Moreover, it is important, that the charge transfer process must be quicker than the recombination of the electron-hole pair, since the latter one results in undesirable heat production instead of chemical reactions required for the utilization of the photocatalysts.

These processes can be illustrated using the example of titanium dioxide $\left(\mathrm{TiO}_{2}\right)$ as follows [2]: In the

$$
\mathrm{TiO}_{2}+\mathrm{h} v \rightarrow \mathrm{TiO}_{2}\left(\mathrm{e}^{-}+\mathrm{h}^{+}\right)
$$

excitation process (where $\mathrm{h}$ is the Planck constant and $v$ is the frequency of the irradiation) the photogenerated electrons and holes can take part in charge transfer (redox) reactions. It is widely accepted, that in the presence of oxygen the photogenerated electrons can reduce the oxygen adsorbed on the surface resulting in the formation of superoxide anion.

$$
\mathrm{e}^{-}+\mathrm{O}_{2} \rightarrow \cdot \mathrm{O}_{2}^{-}
$$

The photogenerated holes can either be trapped by water molecules or hydroxide ions resulting in hydroxide radicals:

$$
\begin{gathered}
\mathrm{h}^{+}+\mathrm{H}_{2} \mathrm{O} \rightarrow \cdot \mathrm{OH}+\mathrm{H}^{+} \\
\mathrm{h}^{+}+\mathrm{OH}^{-} \rightarrow \cdot \mathrm{OH}
\end{gathered}
$$


Or the surface adsorbed substrate (S) - an organic matter in this case - can react with either the holes or the electrons depending on its redox characteristics:

$$
\begin{aligned}
& \mathrm{S}+\mathrm{e}^{-} \rightarrow \cdot \mathrm{S}^{-} \\
& \mathrm{S}+\mathrm{h}^{+} \rightarrow \cdot \mathrm{S}^{+}
\end{aligned}
$$

The as-formed radicals can degrade the organic matter in the subsequent steps. Apart from the redox reactions, the photogenerated electrons and holes can also recombine with each other,

$$
\mathrm{e}^{-}+\mathrm{h}^{+} \rightarrow \text { heat }
$$

or the electrons can be trapped

$$
\mathrm{e}^{-} \rightarrow \mathrm{e}^{-} \text {trapped }
$$

resulting in $\mathrm{Ti}(\mathrm{III})$ centers in the conduction band.

Following the photoelectrocatalytic water splitting demonstrated by Fujishima and Honda [1], scientist explored the application possibilities of semiconductors which are virtually unlimited. They can be used as gas sensors to detect and quantify the components of different headspaces [3-7], for the purification of air, elimination of foul gases and odor control [2, 8-10], to fabricate superhydrophilic [11-13] self-cleaning [14-17] or antibacterial surfaces [13, 18, 19], for the production of lithium ion batteries [20-23], for photocatalytically-assisted organic synthesis [24] or even to apply them in cancer treatment for the targeted killing of tumor cells $[13,25,26]$ just to name a few.

If two (or more) electrodes are attached to the semiconductor then its electrical resistance can be measured which changes on exposure according to the different type of gas interacting with the surface [6]. Thus, a given semiconductor can be utilized for the detection of different gases like hydrogen, oxygen, ozone, carbon monoxide, hydrogen sulfide and organic vapors for example acetone, methanol or ethanol.

The usage of photocatalysts in the energy industry is becoming increasingly important as well, the development of dye-sensitized solar cells (DSSCs) bears considerable interest in particular. Although this topic does not belong in the field of heterogeneous photocatalysis in the strict sense, still, it uses semiconductors whose excitation is carried out the same way, thus the application of semiconductors in photovoltaic systems is worth mentioning. In these systems the photogenerated electron is migrated to a collector electrode - in contrast with it being utilized to generate radicals - resulting in the generation of electric current $[27,28]$. The energy industry and heterogeneous photocatalysis are closely 
intertwined since the achievements of solar cell development are immensely beneficial for heterogeneous photocatalytic applications as well, since the as-developed semiconductors are very likely to be applicable in both processes [29].

Heterogeneous photocatalysis can play an important role in the reduction of carbon dioxide as well [30,31], which is of considerable importance since it is the most significant long-lived greenhouse gas in Earth's atmosphere. It also enables the production of hydrogen gas, an alternative green energy source, as photocatalysts can transform electromagnetic radiation (even solar energy) into chemical energy [23, 32-49]. The search for well utilizable 'clean' energy sources is one of the biggest challenges of the present time and the research works regarding this topic holds great potential as the oxidation of hydrogen yields water without carbon dioxide emission. In aqueous systems in the absence of molecular oxygen a potential electron acceptor is hydrogen in the +1 oxidation state, resulting in the formation of molecular hydrogen. For this to happen the photocatalyst must contain active sites where the overpotential of hydrogen evolution is low, which is made possible most commonly by the deposition of noble metals to the photocatalyst's surface.

Probably the most important application of heterogeneous photocatalysis is to use them for the protection of the environment; for water purification and wastewater treatment in particular. The first successful attempt to apply photocatalysts for environmental protection purposes dates back to 1977, when Frank and Bard removed cyanide ions from aqueous solutions via their oxidation by valence band holes [50]. During my research work I mainly focused on water treatment applications, thus in the following paragraphs I am going to present this topic in more detail.

\subsection{Titanium dioxide and its photocatalytic applications}

For the practical application of a photocatalyst, it shall meet numerous requirements. It shall not be used up during the reactions in which it takes part, it must be photostable, biologically-chemically inert and non-toxic. Furthermore, it should be cheap, easily accessible, widely available in great quantity and applicable against wide range of pollutants. It is worth mentioning, that a photocatalyst being inert and being able to react with organic pollutants at the same time can be somewhat controversial, and there are numerous publications in the literature examining the adverse effects of photocatalysts on living organisms, emphasizing the fact, that these materials should be applied with caution [51]. Taking these requirements into account titanium dioxide is one of the most thoroughly 
investigated and most suitable photocatalyst to be taken into consideration for practical applications.

$\mathrm{TiO}_{2}$ is an n-type semiconductor due to it being oxygen deficient, which means that the charges are transferred via excess electrons. Natural titanium dioxide has four polymorphs: rutile, anatase, brookite and the very rare akaogiite, although the two latter only exist in the form of high-pressure minerals $[52,53]$ and their production is burdensome, thus in practical applications only the first two is used. Metastable brookite and anatase transform into thermodynamically stable rutile during calcination above $600^{\circ} \mathrm{C}$ [54]. In all polymorphs titanium $\left(\mathrm{Ti}^{4+}\right)$ is surrounded by six oxygen $\left(\mathrm{O}^{2-}\right)$ forming $\mathrm{TiO}_{6}$ octahedra (Fig. 2) which are connected to each other with two, three or four common edges in the case of rutile, brookite and anatase, respectively.

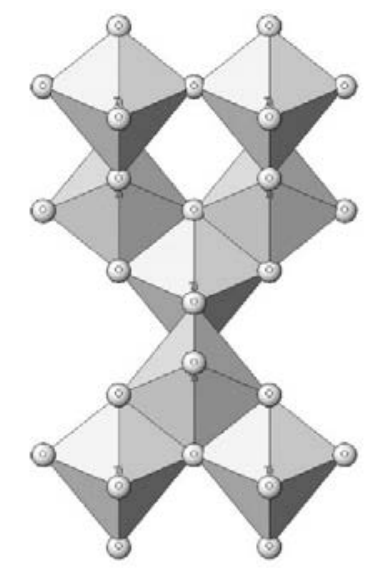

(a)

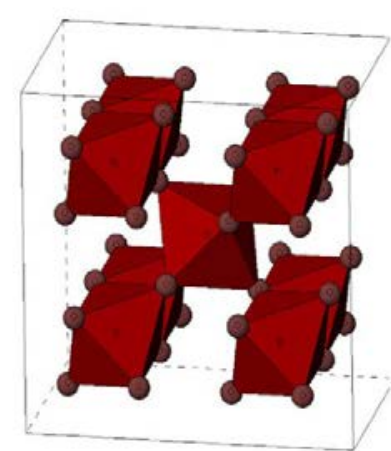

(b)

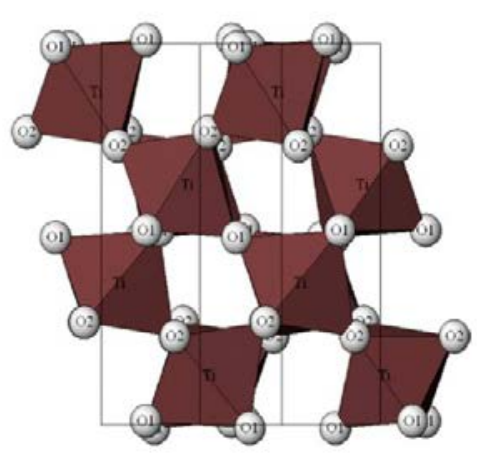

(c)

Figure 2 Crystalline structures of titanium dioxide: (a) anatase, (b) rutile, (c) brookite. This figure was taken from ref. [2], p. 333.

Rutile and anatase are tetragonal, while brookite has orthorhombic structure. The band gaps of anatase and rutile are $3.23 \mathrm{eV}$ and $3.02 \mathrm{eV}$, respectively, while in the case of brookite this value varies from 2.96-3.4 eV [55]. In most cases anatase has superior photocatalytic activity compared to rutile owing to different amount of hydroxyl groups and different oxygen adsorption-light absorption properties [56,57]. Although anatase is more commonly used in photocatalytic applications, it is worth mentioning, that it can only be excited with photons below $387 \mathrm{~nm}$ wavelength (when it comes to excitation via electromagnetic radiation), thus it cannot utilize visible light (which consists $\sim 40 \%$ of sunlight). Rutile, on the other hand, can be excited to some extent with visible light (having a band gap equal to $411 \mathrm{~nm}$ ), thus it often proves to be more suitable for photocatalytic applications under visible 
light irradiation and has more beneficial properties from certain aspects (e.g. stability, chemical inertness) [58].

As mentioned above, titanium dioxide being a semiconductor can be used in various ways, but probably its most important field of application is photocatalytic water treatment [2]. Mainly due to human activities numerous substances are discharged into waters which tend to be toxic, chemically stable, persistent, carcinogenic and liable to biomagnification just to name a few. It is worth mentioning, that current municipal wastewater treatment plants are unable to completely remove certain pollutants from wastewaters due to their low concentration or resistant structure, but by the application of photocatalysis even these problematic pollutants can be degraded [59]. The degradation efficiency of various pollutants depends on various factors such as the type and concentration of the photocatalyst, structure and concentration of the pollutant, composition and $\mathrm{pH}$ of the water to be treated, type and intensity of the light source and concentration of the oxidants formed during the treatment [60-62]. It is important to highlight, that despite its potential, the application of $\mathrm{TiO}_{2}$ nanoparticles in wastewater treatment is still limited due to the following reasons: (i) they are susceptible to agglomeration; (ii) without being fixed on a surface, $\mathrm{TiO}_{2}$ particles have to be removed from the water to be treated which involves additional costs; (iii) the intrinsic band gap of $\mathrm{TiO}_{2}$ is too wide to utilize visible light [63]. There are extensive number of publications in the literature in which titanium dioxide was applied to degrade all kinds of pollutants such as phenol [40, 64-74], organic dyes [2, 60, 75-82], pesticides [83-87], pharmaceuticals [88, 89] or to inactivate bacteria in disinfection processes [67, 68, 90-95].

Phenols are common pollutants to be introduced into the aquatic environment through anthropogenic means. They are mainly used as precursors for plastics such as polycarbonates and epoxide resins [96]. They occur in wastewaters in the form of phenol, bisphenol, chlorophenol and nitrophenol originating from various herbicides, azo dyes, medical goods, and water disinfection. They are highly toxic and suspected carcinogens; thus, their removal from wastewaters is imperative. Phenol, being a poorly adsorbing material, is degraded during photocatalytic applications mainly in the liquid phase via hydroxyl radicals resulting in various intermediates (e.g. resorcinol, catechol, hydroquinone). The degradation mechanism of phenol is rather complex; its degradation pathway (Fig. 3) in the case of $\mathrm{TiO}_{2}$ under UV, visible and solar light irradiation is greatly summarized in the comprehensive study of Ahmed et al. [62]. 


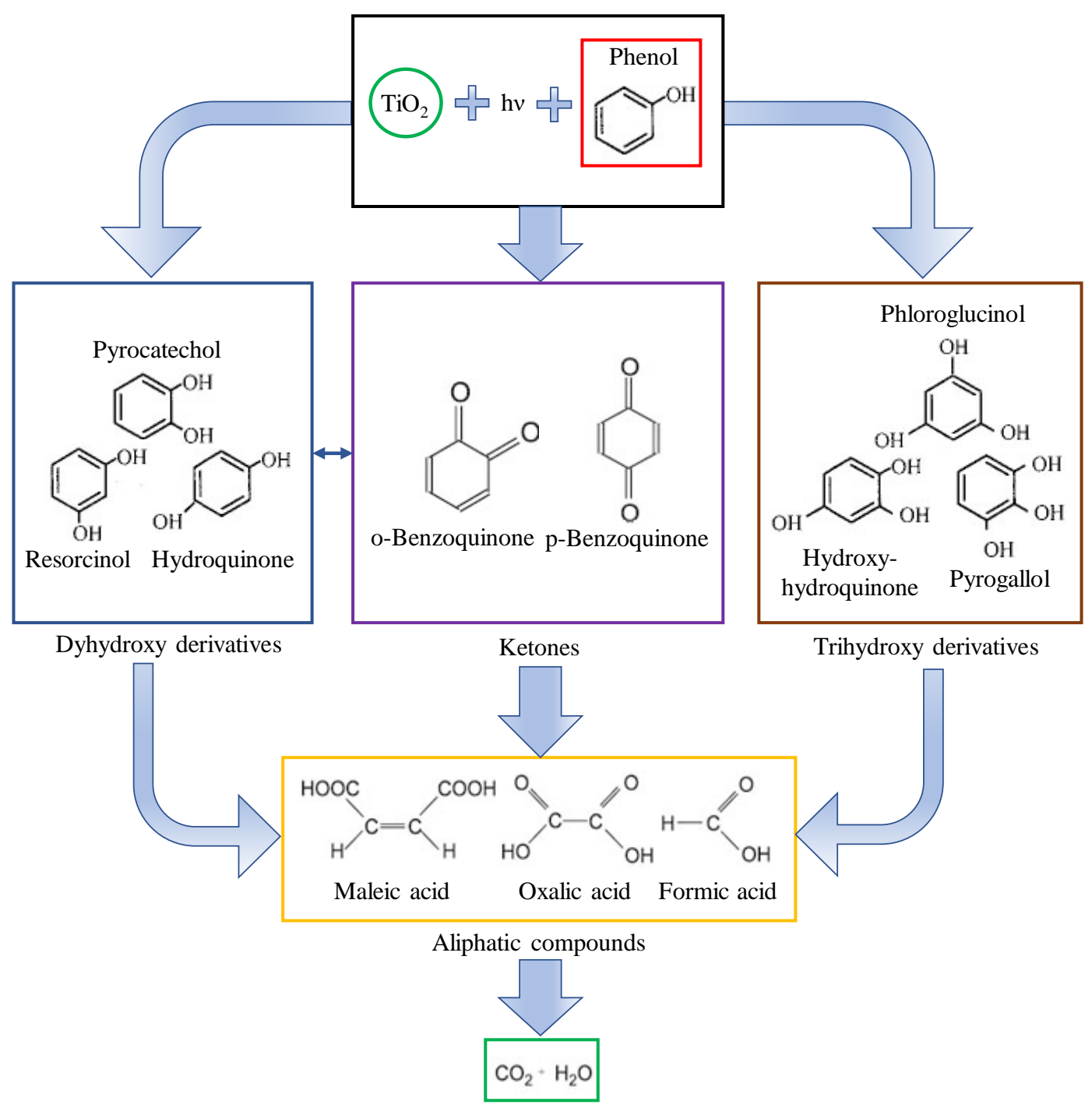

Harmless end products

Figure 3 Possible intermediates of phenol during its photocatalytic oxidation [71, 97-100]. One of the most important aspects this study highlights, is that it is possible to mineralize even as resistant molecules as phenol through photocatalytic means resulting in harmless end products like inorganic ions, carbon dioxide and water. Based on the above-mentioned considerations, in my Ph.D. Dissertation (among others) I used mainly phenol as model contaminant to determine the photocatalytic activity of the investigated $\mathrm{TiO}_{2}$ photocatalysts.

Oxalic acid is another widely investigated model pollutant which can be eliminated by photocatalytic means [34, 40, 69, 101]. In contrast with phenol, it is a strongly adsorbing compound. In different protolytic forms it frequently appears in domestic and industrial wastewaters due to its application in pharmaceutical processes, detergents, metallurgy, textile industry and as cleaning and decontaminating agents [102]. Another reason for its recurrent presence is that it is a common intermediate during the oxidation of more complex 
compounds. Due to these reasons in some cases I used oxalic acid as model pollutant besides phenol as well.

The most common, widely accepted reference $\mathrm{TiO}_{2}$ photocatalyst is Aeroxide P25, which has been extensively investigated in the degradation of pharmaceuticals. Against wellknown analgesic and antipyretic drugs such as paracetamol and diclofenac, P25 proved to be efficient to degrade them either yielding intermediates less harmful compared to the initial material or deactivating them, thus enabling the possibility to discharge them into the environment [103, 104]. Active compounds of contraceptives like 17- $\beta$ estradiol, nomegestrol and 17- $\alpha$ ethynylestradiol were demonstrated to be harmful both to humans and wildlife and these materials were also successfully eliminated by photocatalytic mineralization [59].

Another type of material representing serious risk are the cationic and anionic organic dyes applied in the textile industry, which not only poses aesthetic problems, but the dyes themselves or their intermediates can be carcinogenic. Contaminations conducted by dyes are especially problematic in developing countries where wastewaters of textile industries are discharged into the environment without any treatment. Dyes are commonly used as model pollutants in photocatalytic oxidation reactions, partly because by using visible spectrophotometry their concentration can be easily monitored; however, it should be taken into account that dyes also absorb light in the visible range, and the influence of this photoabsorption by them must be excluded for the evaluation of the real photocatalytic activity of semiconductors. The most commonly used dye as model pollutant is methylene blue [76, 77, 81], although methyl orange [75, 76, 80], Rhodamine B [80] and various other azo dyes [60, 79] are frequently applied as well. Even though methylene blue has relatively large molecular weight $\left(\mathrm{Mr}_{\mathrm{r}}=284 \mathrm{~g} \cdot \mathrm{mol}^{-1}\right)$ still, complete mineralization can be achieved provided sufficient amount of time is ensured for the treatment [81].

There are numerous examples in the literature for the photocatalytic degradation of pesticides. Pesticide is a collective term, including substances that are meant to control pests and weeds, including insecticides, herbicides and other biocides. However, they pose a threat to the soil, surface and groundwater when used improperly - from which carcinogens or the ones having endocrine-disrupting effects are of particular concern [85] - resulting in various adverse health effects, ranging from skin irritation to more severe effects such as affecting the nervous system, hormones and causing reproductive problems. In the publication of Kovács et al. among various advanced oxidation processes heterogeneous photocatalysis (by 
applying Aeroxide $\mathrm{P} 25 \mathrm{TiO}_{2}$ ) was found to be the most effective for the mineralization of pesticides [84].

By using titanium dioxide in photocatalytic applications not only organic water pollutants but microbiological pollutants can be eliminated as well, resulting in the disinfection of the treated water. The first photocatalytic water disinfection was conducted by Matsunaga et al. in 1985, who carried out the photoelectrochemical oxidization of microbial cells, killing them by the inhibition of their respiratory system [105]. Jacoby et al. showed via ${ }^{14} \mathrm{C}$ radioisotopic measurements that the organic matter content of bacterium cells can be mineralized entirely resulting in carbon dioxide [106]. The merit of this publication was that it also augured well the potential application of semiconductors to create self-cleaning antibacterial surfaces.

\subsection{Strategies for improving the photocatalytic activity of titanium dioxide}

As outlined above, titanium dioxide has immense potential to be used in various applications; however, it has some important drawbacks which limit its practical application possibilities. It cannot be excited efficiently by visible light and its photocatalytic activity is usually not high enough to replace already existing technologies. This is the reason that a large majority of titanium dioxide-related research works focus on enhancing its photocatalytic activity (which often comes together with increasing its visible light excitability). These methods can be categorized into two groups: morphological modifications (such as increasing porosity or specific surface area) and chemical modifications (altering the $\mathrm{TiO}_{2}$ structure with additional components) involving the following methods: doping with various elements and oxygen rich modification, metal deposition, construction of composites and dye sensitization [2, 63]. In my Ph.D. work I have dealt mainly with oxygen rich modification and morphological modification; moreover, with metal deposition and composites to a lesser extent. Accordingly, in the following sections I am going to present these techniques in this order.

\subsubsection{Doping and oxygen rich modification}

One of the main drawbacks of $\mathrm{TiO}_{2}$ that it can only be excited efficiently by UV light, which contains only $~ 3-6 \%$ of the solar spectrum [92, 107], while visible light (taking up 
$\sim 44 \%$ ) is the one, which comprise most of the solar energy that reaches Earth's surface (Fig. 4) $[108]$.

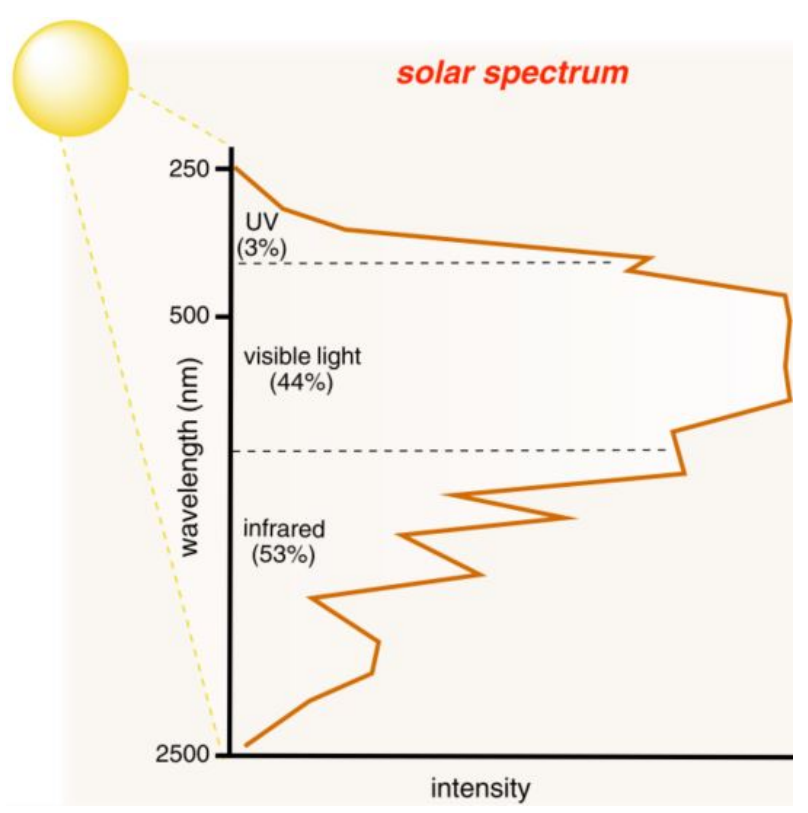

Figure 4 Composition of the solar spectrum that reaches the Earth's surface. This figure was taken from ref. [108], p. 986 and ref. [109], p. 313. Reprinted with permission from AAAS.

Fig. 4 demonstrates that it would be plausible to use the Sun as light source for the construction of environmentally friendly water treatment plants instead of artificial UV lamps, which involves high investment, handling and maintenance costs [91, 92, 108, 110]. It is worth mentioning, that although near infrared light comprises $\sim 53 \%$ of the solar spectrum, it conveys insufficient amount of energy for certain photocatalytic processes to occur, therefore developing photocatalysts which can utilize near infrared light remains to be a challenge [111]. Doping is one of the most effective ways to enhance the photocatalytic activity (and visible light response) of titanium dioxide.

Doping involves the incorporation of a given element in ionic form into the lattice structure of $\mathrm{TiO}_{2}$. The purpose of doping is to optimize the optical properties of $\mathrm{TiO}_{2}$ to enable visible light harvesting by modifying its relatively large band gap and electronic structure and to reduce the recombination rate of the photogenerated charge carriers. The inhibition of charge recombination (which is closely intertwined with the enhancement of interfacial charge transfer) is due to the entrapment of valence band holes or conduction band electrons in the defect sites [112]. In most cases the doped ions introduce additional energy levels (defect states) into the band structure of the semiconductor between the VB and CB, 
enabling the entrapment of photogenerated electrons and holes $(9,10)$, thus allowing them to migrate to the surface [113] and interact with acceptors/donors instead of recombination.

$$
\begin{aligned}
& \mathrm{M}^{\mathrm{n}+}+\mathrm{e}^{-} \rightarrow \mathrm{M}^{(\mathrm{n}-1)+} \\
& \mathrm{M}^{\mathrm{n}+}+\mathrm{h}^{+} \rightarrow \mathrm{M}^{(\mathrm{n}+1)^{+}}
\end{aligned}
$$

The $\mathrm{M}^{\mathrm{n}+} / \mathrm{M}^{(\mathrm{n}-1)^{+}}$system's energy level is somewhat below the $\mathrm{CB}$, while the $\mathrm{M}^{\mathrm{n}+} / \mathrm{M}^{(\mathrm{n}+1)^{+}}$ system's energy level is somewhat above the VB resulting in the red shift of the photocatalyst (in the absorption spectrum) compared to intrinsic semiconductors. The reason behind enabled visible light harvesting is that electronic transitions from the valence band to the defect states or from the defect states to the conduction band is possible, because the distance in energy between them is lower compared to the band gap, so these transitions are allowed under sub-band gap irradiation [112]. Doping can also influence the crystallographic plane structure of $\mathrm{TiO}_{2}$ which affects the photocatalytic activity. Different crystal surfaces possess different surface energy levels in the case of $\mathrm{CB}$ and $\mathrm{VB}$ and these differences in energy levels determine the movement of electrons and holes to different crystal facets [113, 114].

Doping methods can be categorized as follows: self-doping [115, 116], non-metal and metal doping/co-doping and oxygen rich $\mathrm{TiO}_{2}$ modification $[2,113]$. Probably the most promising and frequently applied element as dopant is nitrogen [43, 66, 68, 69, 71, 87, 94, 117-121], since it can be introduced easily into the $\mathrm{TiO}_{2}$ structure (having comparable atomic size with oxygen, high stability and ionization energy), but there are numerous examples in the literature for the application of fluorine- [122], carbon- [87, 123, 124], sulfur- [68, 87, 121, 125], phosphorous [107], iodine- [67, 69], iron- [68, 69, 75, 120], silver- [126, 127], gold- [127], platinum [127], cerium- [126] and cadmium-doped [93] titania just to name a few. Lastly, oxygen rich $\mathrm{TiO}_{2}$ modification is a novel way to enhance the photocatalytic activity (and visible light excitability) of titanium dioxide photocatalysts by the application of hydrogen peroxide [2, 128-135]. It is worth mentioning that the classification of this method is not consistent in the literature: it can be categorized both as a doping process [2] or as a sensitization technique [130] (similar to dye sensitization) as well. Moreover, it is also not consistent in the literature whether to use anatase or rutile phase $\mathrm{TiO}_{2}$ to achieve the best results in terms of photocatalytic activity: there are examples when rutile phase $\mathrm{TiO}_{2}$ proved to be more active [131] and vice versa [128] and in some rare cases amorphous $\mathrm{TiO}_{2}$ [130] showed the best performance. Since this is one of the techniques, I have applied during 
my Ph.D. work to enhance the photocatalytic efficiency, I am going to describe it in more detail.

It is well-known, that Ti(IV) salts form stable yellow solutions when dissolved in hydrogen peroxide due to the formation of Ti(IV) peroxo complexes. The exact structure and ratio of Ti:O within the Ti(IV) peroxo complexes has not yet been fully clarified [136]. Based on the experiments of Mühlebach et al. in very acidic solutions below $\mathrm{pH}=1$ peroxo titanium complex is mononuclear $\left(\mathrm{TiO}_{2} \mathrm{OH}^{+}\right)$and between $\mathrm{pH}=1-3$ it condenses to a dinuclear species $\left(\mathrm{Ti}_{2} \mathrm{O}_{5}\right.$; in the form of $\left.\mathrm{Ti}_{2}\left(\mathrm{O}_{2}\right)_{2} \mathrm{O}_{a q}{ }^{2+}\right)$ [137]. It was suggested, that in this latter form the metal atoms are bridged by a $\mu$-oxygen and two $\mu$-peroxy groups and the sixfold coordination is completed either by the ligand atoms of a chelating agent or $\mathrm{H}_{2} \mathrm{O}$. If regular octahedral structure is assumed and the grouping of $\mathrm{Ti}-\mathrm{O}-\mathrm{O}-\mathrm{Ti}$ atoms is planar, then the Ti-O distance is $1.94 \AA$, the $\mathrm{O}-\mathrm{O}$ distance is between 1.32 and $1.488 \AA$ and the Ti-OTi angle is between 103 and $107^{\circ}$ resulting in a remarkably strain-free complex (Fig. 5). This proposed structure would also explain the stability of titanium peroxo complexes which slowly decompose releasing oxygen, although it can be stable even for a year according to Cai et al. [138].

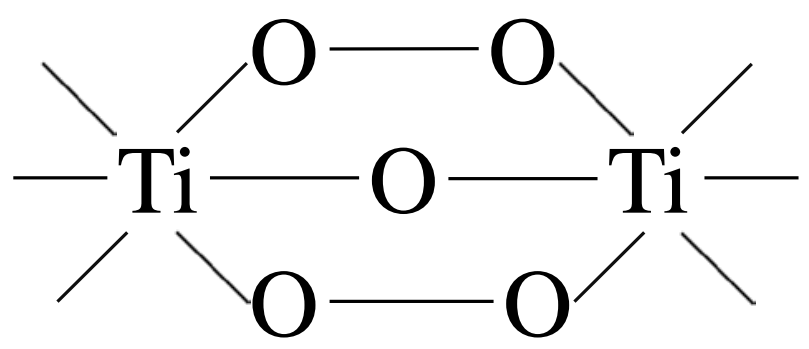

Figure 5 Proposed structure of peroxo titanium complex. This figure was taken from ref. [136].

Enrichment of $\mathrm{TiO}_{2}$ with oxygen is carried out by the application of hydrogen peroxide either after or during its synthesis. In the former case typically commercial titanium dioxides are applied whereas in the latter case hydrogen peroxide is added to the synthesis mixture with the goal of enhancing the visible light excitability of as-prepared titania. Takahara et al. examined the photooxidation of cyclohexane under visible light irradiation using hydrogen peroxide with commercial titania and they have found, that the photooxidation process only occurred when $\mathrm{H}_{2} \mathrm{O}_{2}$-treated samples were applied [131]. They explained this phenomenon by assuming a weakened $\mathrm{O}-\mathrm{O}$ bond in the complex directly 
cleaved by visible light leading to the formation $\bullet \mathrm{OH}$ radicals. For the explanation of similar findings $\mathrm{Li}$ et al. proposed that the as-formed peroxide complex undergoes a photoreaction: an electron from the photoexcited complex can migrate to the $\mathrm{CB}$ of $\mathrm{TiO}_{2}$ after photoexcitation and this electron is transferred to a $\mathrm{H}_{2} \mathrm{O}_{2}$ species resulting in the generation of $\mathrm{OH}^{-}$and $\bullet \mathrm{OH}$ radical [132]. Similar mechanism and the same conclusions were drawn by Shankar et al. who synthesized peroxo group-containing titania and examined the photocatalytic activity by the photocatalytic oxidation of methanol solution (Fig. 6) [129].

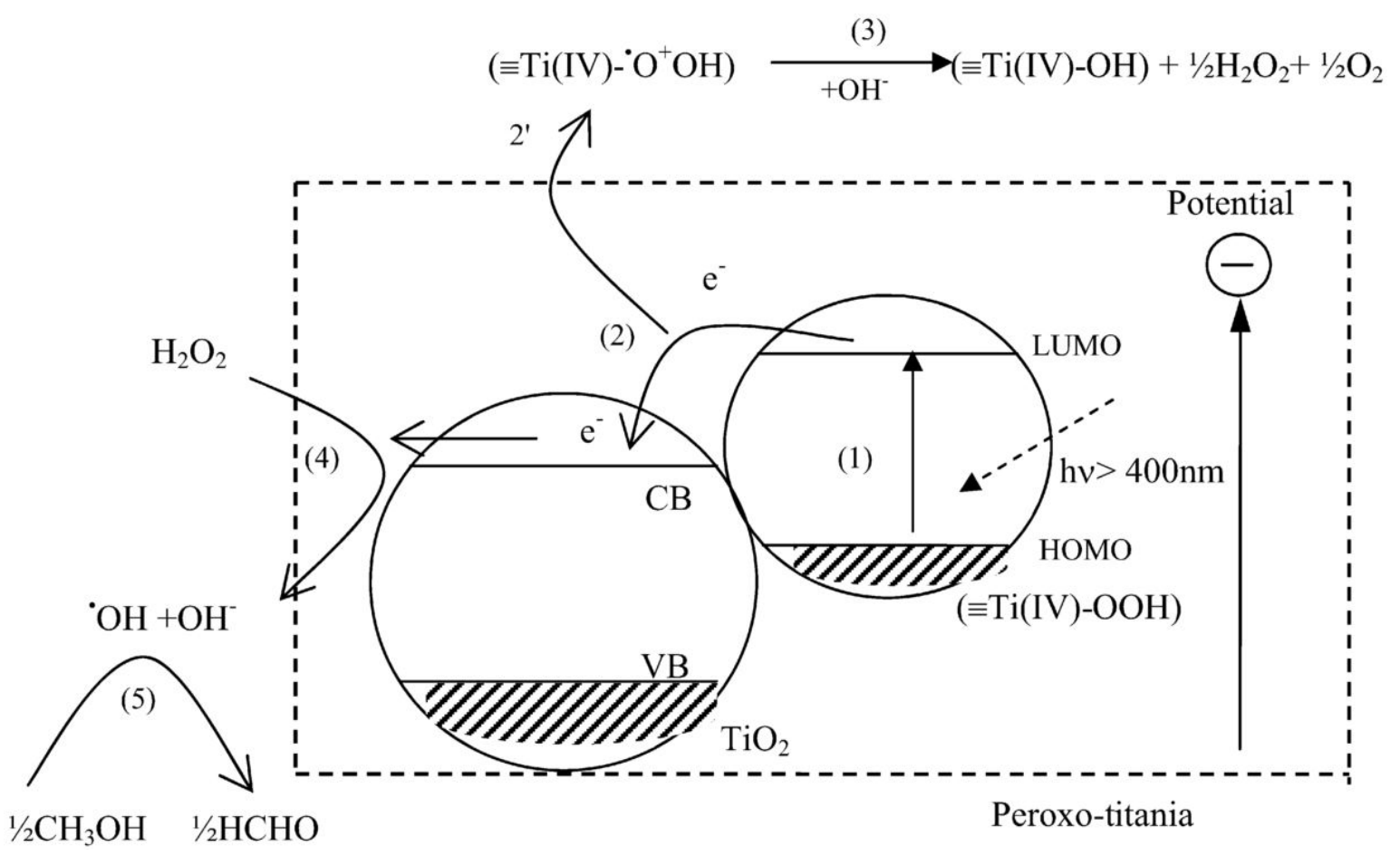

Figure 6 Proposed mechanism of the photocatalytic degradation of methanol via peroxo titania. This figure was taken from ref. [129], p. 136.

Following the visible light excitation (1) of peroxo titania complex ( $\equiv \mathrm{Ti}(\mathrm{IV}) \mathrm{OOH})$ an electron is transferred (2) into the $\mathrm{CB}$ of the $\mathrm{TiO}_{2}$, which then migrates to a $\mathrm{H}_{2} \mathrm{O}_{2}$ site (4) where the adsorbed methanol is oxidized (5) by the as-formed $\bullet \mathrm{OH}$ radicals. Concurrently with this process, the peroxo complex after excitation in the form of $\equiv \mathrm{Ti}(\mathrm{IV}) \bullet \mathrm{O}^{+} \mathrm{OH}$ reacts with $\mathrm{OH}^{-}$(3) resulting in $\equiv \mathrm{Ti}(\mathrm{IV})-\mathrm{OH}, \mathrm{H}_{2} \mathrm{O}_{2}$ and molecular $\mathrm{O}_{2}$. In this publication it was also proved by FT-IR measurements that the enhanced photocatalytic activity of the samples could be attributed to the existence of peroxo species on the $\mathrm{TiO}_{2}$ surface. Etacheri et al. synthesized oxygen rich, anatase phase titania applying $\mathrm{TiO}_{2}: \mathrm{H}_{2} \mathrm{O}_{2}$ 1:2-16 ratios followed by their calcination at $600-1000{ }^{\circ} \mathrm{C}$ [128]. They observed, that increasing amounts of hydrogen peroxide resulted in the decrease of band gap, thus the photocatalysts could be 
excited more and more efficiently by visible light. The formation of peroxo titania complexes was reinforced by FT-IR measurements in which the intensity of $\mathrm{O}-\mathrm{O}$, Ti-O-O and Ti-O-Ti steadily increased by increasing amounts of applied $\mathrm{H}_{2} \mathrm{O}_{2}$. $\mathrm{TiO}_{2}$ sample prepared by applying the largest amount of $\mathrm{H}_{2} \mathrm{O}_{2}\left(\mathrm{Ti}: \mathrm{H}_{2} \mathrm{O}_{2}=1: 16\right)$ proved to be the most efficient in methylene blue degradation even surpassing the photocatalytic activity of reference commercial Aeroxide $\mathrm{P} 25 \mathrm{TiO}_{2}$. The reason for the enhanced photocatalytic activity and band gap narrowing was examined by XPS and photoluminescence (PL) measurements and it was found that by increasing amounts of $\mathrm{H}_{2} \mathrm{O}_{2}$ the $\mathrm{VB}$ of the $\mathrm{TiO}_{2}$ shifted upwards; moreover, PL measurements also yielded the same conclusions, that in the case of oxygen rich $\mathrm{TiO}_{2}$ decreased radiative electron-hole recombination rate was observed due to the relatively smaller amount of oxygen vacancies in this sample. Savinkina et al. compared post-synthesis and simultaneous sensitization methods of $\mathrm{TiO}_{2}$ photocatalysts using methylene blue, methyl red and hydrogen peroxide and it was found, that sensitizing titania during the synthesis (compared to post-synthesis sensitization) resulted in significantly greater photocatalytic efficiencies, which was ascribed to the ability of sensitizer to incorporate into the surface of nano-sized titania [134]. The most prominent increase in activity was observed in the case of hydrogen peroxide, which was attributed to the formation of peroxo complexes.

\subsubsection{Morphological modifications}

Morphological modifications are inherently different from chemical modifications as they do not change the crystalline composition of the semiconductor, thus it is not suitable for the enablement and enhancement of visible light excitability. However, the overall efficiency of semiconductors can be significantly enhanced by controlling their morphology. Morphological changes involve tailoring the size, specific surface area, shape, porosity and surface properties. Titanium dioxide with different morphologies such as zero-dimensional (microspheres, nanospheres), one-dimensional (nanotubes, nanowires, nanoneedles, nanorods, nanobelts), two-dimensional (layers, films, sheets) and three-dimensional (hollow spheres, porous spheres, urchin-like spheres) have been extensively investigated in the past decade [2, 49, 94, 139-147]. $\mathrm{TiO}_{2}$ is most commonly applied in the form of monodispersed nanoparticles (solid, i.e. non-porous, non-hollow) with the goal of gain the benefits of small particle size (high surface area, more active sites, reduced bulk recombination) without the detrimental effects associated with very small particle size (low crystallinity, surface 
recombination) [2,63]. Larger diameter leads to lower surface area thus lower number of adsorbed reactants which has a detrimental effect on the photocatalytic efficiency. It is worth mentioning, that the photocatalytic activity of semiconductors is largely dependent on how it is measured; the relative activities of photocatalysts with different specific surface areas are in close relation with the properties of the model pollutant. Controlling the size and morphology of $\mathrm{TiO}_{2}$ spheres is a challenge - due to the high reactivity of $\mathrm{TiO}_{2}$ precursors which can be fine-tuned by the modification of surface charge and steric repulsion of the particles [148]. In 1D $\mathrm{TiO}_{2}$ nanostructures high surface-to-volume ratio can be achieved which results in reduced electron-hole recombination rate and high interfacial charge carrier transfer rate; both properties are beneficial in terms of enhancing the photocatalytic activity [142, 147]. Moreover, vectorial charge transfer and controlled porosity can also be advantageous in this regard [72, 149]. $1 \mathrm{D} \mathrm{TiO}_{2}$ structures already have important applications including DSSCs [150], gas sensing [6, 151] and batteries [20]. $\mathrm{TiO}_{2}$ nanotubes can also be used as photoanodes in electrochemically enhanced photocatalytic disinfection which morphology can be more beneficial than $\mathrm{TiO}_{2}$ films, due to improved charge carrier separation [94, 144]. 2D structures of $\mathrm{TiO}_{2}$ are also of great interest, since they possess characteristics such as low turbidity/high transparency, high smoothness, and the possibility for substrates to easily adsorb to the surface. These properties make them suitable for the construction of self-cleaning coatings and surfaces $[14,15]$. Similarly to $1 \mathrm{D}$ structures, $\mathrm{TiO}_{2}$ films can also be used in gas sensing [4, 5] and DSSCs applications [28]. Among the 3D structures of $\mathrm{TiO}_{2}$, hollow, porous, and urchin-like spheres are worth highlighting due to their various beneficial properties. As Xiang et al. summarized in their review, porous spherical materials, similarly to $1 \mathrm{D}$ and $2 \mathrm{D} \mathrm{TiO}_{2}$ structures, can be used as solar cells and for energy storage likewise, but they have also attracted considerable attention due to their enhanced reactivity and light harvesting [143]. The pores in porous $\mathrm{TiO}_{2}$ particles can serve as a light-transfer path enabling the incident photon flux to reach the interior surface and more light waves to be captured. Urchin-like microspheres can similarly absorb incident light more effectively and also, they are easier to separate from wastewater by filtration and sedimentation methods. Since I did not deal with the above-mentioned morphologies but with the hollow spherical morphology in my Ph.D. work, in the rest of this paragraph I am going to highlight it in more detail.

By the fabrication of hollow spherical morphology $\mathrm{TiO}_{2}$ with low density, large surface/volume ratio can be achieved with exceptional optical, optoelectronic, magnetic, 
electrical, thermal and chemical properties [27, 82, 152, 153]. Due to these features semiconductor-based hollow spheres (HSs) are of great interest to be used as adsorbents, thermal insulation materials, carrier materials for delivery of drugs, DSSCs and (photo)catalysts [73, 145, 146, 154]. From the scope of potential photocatalytic applications what makes (sub-micron scale) hollow spherical morphology intriguing, is that this size is comparable to the wavelengths of UV and visible lights, thus the diffractions on the hollow spheres and the multiple reflections within the hollow cavity can lead to more efficient light harvesting, resulting in increased photocatalytic efficiency of the semiconductor $[145,146]$ (Fig. 7).

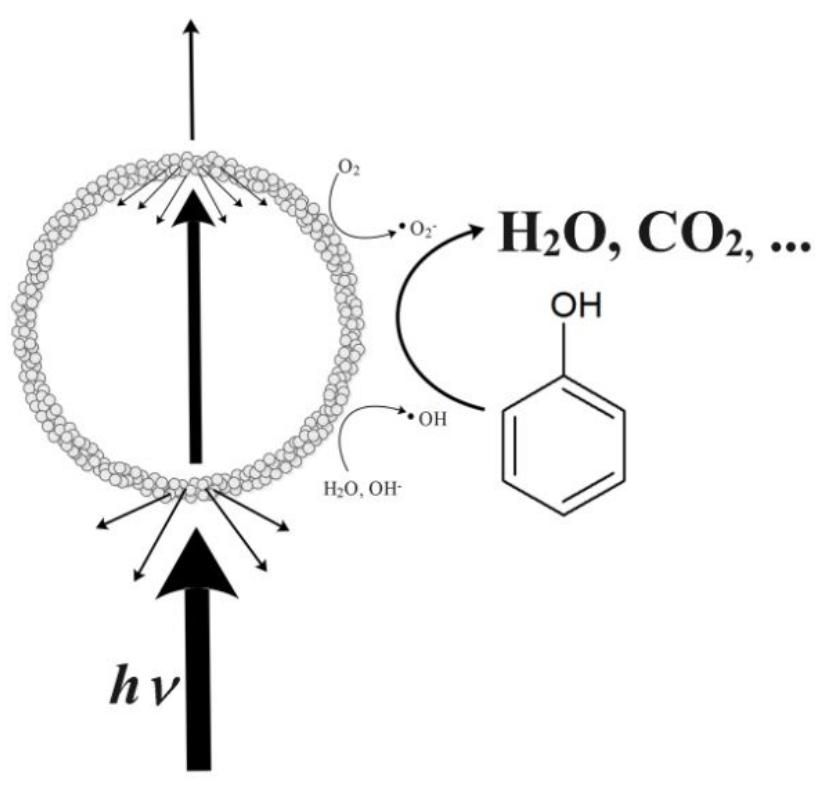

Figure 7 Schematic representation of the enhanced visible light harvesting of hollow spherical $\mathrm{TiO}_{2}$ [73].

For the preparation of spherical hollow structures, the use of various methods (e.g. hydrothermal, sonochemical, template based) have been reported [155], from which the most commonly applied one is the template removal method [156]. Templates can be either hard (metal, inorganic or polymer particles) or soft (supramolecular assemblies of surfactants or polymers) [146] both having their advantages and disadvantages (hard templates enable better control over the qualities of the product but harder to remove, while soft templates are easier to eliminate, but the morphology is more difficult to control). One of the most appropriate template materials are carbon spheres (CSs), due to their environmentally friendly nature and the high hydrophilicity due to the polar $-\mathrm{OH}$ and $-\mathrm{C}=\mathrm{O}$ surface groups [156]. CSs can be prepared by numerous synthesis techniques: arc-discharge, CVD, 
hydrothermal method et cetera [157]. A convenient route to produce micro- or nanosized CSs is the hydrothermal dehydration and carbonization of different carbohydrates (most commonly glucose) $[158,159]$. The properties of these spheres are finely tunable, including diameter, surface area, accretion and carbon layer arrangement [73, 157].

The beneficial effects of the hollow spherical morphology on the photocatalytic activity were reported in numerous publications [21, 146, 155, 160, 161] including our research group [73, 99]. Li et al. synthesized various $\mathrm{TiO}_{2}$ hollow spherical structures together with a solid spherical $\mathrm{TiO}_{2}$ reference and investigated their photocatalytic activity using phenol as model contaminant [146]. The samples possessed similar crystalline structure and specific surface area. They found that reference solid spheres had the lowest photocatalytic performance, which was significantly surpassed by the hollow structures' photocatalytic efficiency and this was attributed to their unique morphology, since the other properties of the photocatalysts were similar. They successfully reinforced this finding by destroying the hollow spherical structure via grinding, which resulted in the slight increase of surface area, still, the photocatalytic activity dramatically decreased, falling back to the efficiency of solid spherical reference. Ao et al. prepared $\mathrm{TiO}_{2}-\mathrm{HSs}$ by precipitation of $\mathrm{TiO}_{2}$ onto the surface of hydrothermally prepared CSs and demonstrated enhanced photocatalytic activity in photocatalytic decomposition of methylene blue which was partly attributed to the unique morphology [155]. It is important to mention that - as described previously even so there are numerous publications about the successful photocatalytic activity enhancement due to the unique hollow spherical morphology, the exact mechanism of the process is still unclear. Additionally, for the fabrication of visible light active titania chemical modifications are required, morphology control by itself is not suitable to achieve this, thus it is plausible to combine it with another technique e.g. noble metal deposition [2, 143].

\subsubsection{Metal deposition}

To extend the spectral response and increase the photocatalytic activity of $\mathrm{TiO}_{2}$ both transition metals and noble metals can be used. As Pelaez et al. summarized, although there are numerous examples in the literature, in which the deposition of transition metals yielded positive results; however, in a lot of cases the results were mixed or negative due to the following factors [2]: 
- They may act as recombination sites for the photogenerated electrons and holes lowering quantum efficiency;

- They can cause thermal instability in the case of anatase titania;

- Despite decreasing the band gap (by introducing new energy levels between the VB and CB) the photocatalytic activity either decreased or did not increase significantly since transition metal deposition proved to be less effective than introducing them into the $\mathrm{TiO}_{2}$ framework;

- Promoted charge carrier recombination at metal sites and photocorrosion impose further limitations.

Noble metal deposition is a more frequently applied method to increase the photocatalytic activity of titania [40, 43, 101, 162-168]. In this case the photogenerated electron in the CB of the nanoparticle can migrate to the as-deposited noble metal and get trapped, leading to more effective charge separation (meaning decreased $\mathrm{e}^{-} / \mathrm{h}^{+}$pair recombination) and enhanced photocatalytic activity [127, 169]. These deposited noble metals can have a beneficial influence on the surface characteristics of $\mathrm{TiO}_{2}$ and possess catalytic properties by themselves. From the point of photocatalytic activity and cost effectiveness it is of great importance that the noble metals are applied in rather low amounts (0.1-2 wt\%), since higher amount can result in promoted charge recombination and inactivation of the titania surface $[167,168]$. Deposition of noble metals can also enable the production of hydrogen, an alternate green energy source (as already described it in Section 2.2.).

\subsubsection{Construction of composites}

Composite materials are heterogeneous systems produced by the coupling of two or more constituents. The chemical composition and shape of the constituents are different in most cases. The main idea of them is to develop such new features for the composite materials which the constituents do not possess by themselves and to compensate the disadvantages of the individual components. The interface between the constituents plays a pivotal role in the development of the characteristics of composites. Titanium dioxide possesses excellent charge separation properties; however, the recombination of charge carriers can easily occur as well. This can be alleviated - while enhancing the photocatalytic activity of $\mathrm{TiO}_{2}$ at the same time - by adding such components to it which can (i) hinder the recombination of charge carriers (either by trapping or transferring them to the other 
constituent); (ii) increase the surface area (thus increasing the number of active sites capable of initiating charge separation); (iii) reduce its band gap; (iv) modify its shape and (v) modify its surface properties [2, 72, 170-175]. In the topic of composites it is worth highlighting that a promising direction is to make composites using different forms of carbon, e.g. carbon nanotubes [94, 176-178], graphite oxide [179], activated carbon [180], graphene [181] and graphene oxide [95].

\subsubsection{Dye sensitization}

Photosensitizers are molecules (such as Ru(bpy) $3^{2+}$, Erythrosin B) that can be activated by light and make the excitation process more efficient. When adsorbed on the surface of a semiconductor (either by physisorption or chemisorption), the photogenerated electrons of photosensitizers can migrate to the CB of the semiconductor, provided these electrons has a more negative potential compared to the CB. Then, the electrons can similarly take part in redox reactions. Dye photosensitization is one of the most effective ways to increase the visible light excitability of $\mathrm{TiO}_{2}$ [2]. The mechanism of the photodegradation of pollutants via dye sensitized $\mathrm{TiO}_{2}$ is as follows: after the absorption of light, an electron from the highest occupied molecular orbital (HOMO) must be excited to the lower unoccupied molecular orbital (LUMO) of a dye. Then, the dye becomes a cationic radical while the excited dye molecule transfers electrons to the $\mathrm{CB}$ of $\mathrm{TiO}_{2}$ which acts only as a mediator to transfer electrons from the dye to the substrate on the $\mathrm{TiO}_{2}$ surface. This mechanism is exploited in DSSCs [28, 150]. It is important to highlight, that the semiconductor can degrade the photosensitizer in the process, thus it must be protected during application. 


\section{Aims of the thesis}

In the Research Group of Environmental Chemistry, led by Prof. Klára Hernádi, multiple methods were already applied successfully to enhance the photocatalytic activity of various semiconductor photocatalysts. This includes doping with various elements and the development of composites in general. During my research work I set out to develop novel titanium dioxide-based photocatalysts using other methods, examine their morphostructural properties and investigate their applicability for water treatment purposes.

My main goal is to enhance the photocatalytic activity of titanium dioxides applying various methods and to determine the cause of the increased efficiency. I set out to enhance the photocatalytic activity of $\mathrm{TiO}_{2}$ photocatalysts via oxygen rich modification, morphological modification, and noble metal deposition, then to compare their photocatalytic activity with home-made control references and commercial titanium dioxides. Oxygen rich modification involved anchoring peroxo groups on the $\mathrm{TiO}_{2}$ surface and investigating the effects of applied $\mathrm{H}_{2} \mathrm{O}_{2}$ amount and $\mathrm{pH}$. In the case of morphological modification, my goal is to synthesize carbon spheres and use them as templates to fabricate titanium dioxide hollow spheres. Subsequently, I am going to optimize the synthesis parameters (applying differently treated carbons spheres and calcination temperature) for the fabrication of $\mathrm{TiO}_{2}$ hollow spheres using both home-made $\mathrm{TiO}_{2}$ and commercial $\mathrm{TiO}_{2}$ precursor to develop the $\mathrm{TiO}_{2}$ coating. Finally, my aim is to further increase the photocatalytic activity of $\mathrm{TiO}_{2}$ hollow spheres via Au and Pt deposition.

I am going to characterize the morpho-structural properties of the as-prepared photocatalysts using various techniques (XRD, DRS, SEM, TEM, $\mathrm{N}_{2}$ adsorption, TG, IR, Raman, XPS) and investigate their photocatalytic activities mainly under visible light irradiation using phenol as model pollutant, and in some cases UV lamps as light source and oxalic acid as model pollutant will be applied as well.

I also aim to conduct thorough investigation to reveal the causal relationship between the observed morpho-structural properties and photocatalytic activities resulting from the application of the various synthesis methods in order to better understand those phenomena, which are significant in this regard for the subsequent development of future photocatalysts. 


\section{Experimental part}

\subsection{Materials}

During this work, all materials were used without further purification. For the synthesis of the titanium dioxide photocatalysts, the following materials were used: titanium(IV) butoxide (Sigma-Aldrich, reagent grade, 97\%); hydrochloric acid (VWR Chemicals, 37\%); hydrogen-peroxide (Sigma-Aldrich, 30\%); sodium hydroxide (Molar; a.r.; 50\%) and ultrapure Millipore Milli-Q (MQ) water.

For the preparation of the carbon sphere templates ordinary table sugar (sucrose, Magyar Cukor Zrt., Koronás ${ }^{\mathrm{TM}}$ ); absolute ethanol (Molar Chemicals) and MQ water were applied. For the purification of carbon sphere templates ethanol (Molar Chemicals, 96\%); acetone (Molar Chemicals, 99.96\%) and MQ water were used.

For the deposition of gold and platinum nanoparticles $\mathrm{HAuCl}_{4} \cdot 4 \mathrm{H}_{2} \mathrm{O}$ (SigmaAldrich, 99.9\%) and $\mathrm{H}_{2} \mathrm{PtCl}_{6}$ (Sigma-Aldrich, 99.9\%) were applied, respectively. Trisodium citrate (Sigma-Aldrich, >99\%), was applied to stabilize the growth of the noble metal particles and for their reduction $\mathrm{NaBH}_{4}$ (Alfa Aesar, 98\%) was used.

For the determination of photocatalytic activities phenol (Spektrum 3D, analytical grade) and in some cases oxalic acid (Sharlau, analytical grade) were used as model pollutants.

As reference photocatalysts commercially available Evonik Aeroxide P25 (P25; 90 $\mathrm{wt} \%$ anatase, $10 \mathrm{wt} \%$ rutile), Sigma-Aldrich anatase (AA; $100 \mathrm{wt} \%$ anatase), Sigma-Aldrich rutile (AR; $96 \mathrm{wt} \%$ rutile, $4 \mathrm{wt} \%$ anatase), a rutile-phase titanium dioxide produced by US Research Nanomaterials Inc. (US-R.N. Rutile; 100 wt\% rutile) and our home-made titanium dioxides were used.

\subsection{Syntheses of the titanium dioxide-based photocatalysts}

For the synthesis of rutile phase titanium dioxides via oxygen rich modification the following synthesis method was used. Based on our previous findings [182], to obtain pure rutile the $\mathrm{H}^{+}$concentration has to be set to a specific value, since both higher and lower acid concentration can lead to the formation of anatase [183]. The optimal amount of reactants (in molar ratio) was the following: $\mathrm{Ti}(\mathrm{O}-\mathrm{nBu})_{4}: \mathrm{HCl}: \mathrm{H}_{2} \mathrm{O}=1: 3: 50$. 
Consequently, different amounts of hydrogen-peroxide were added applying the following molar ratios: $\mathrm{Ti}(\mathrm{O}-\mathrm{nBu})_{4}: \mathrm{H}_{2} \mathrm{O}_{2}: \mathrm{HCl}: \mathrm{H}_{2} \mathrm{O}=1: 1-4: 3: 50$ to form peroxo groups on the surface of $\mathrm{TiO}_{2}$ (these samples were named as Rutile-H1-H4 according to the applied molar ratio of $\mathrm{H}_{2} \mathrm{O}_{2}$ compared to Ti ions). Thus, $7.83 \mathrm{~mL}$ hydrochloric acid and $3.22-12.88 \mathrm{~mL}$ hydrogen-peroxide were added in 19.84 - $12.46 \mathrm{~mL}$ MQ water during intensive magnetic stirring, then $10.64 \mathrm{~mL} \mathrm{Ti}(\mathrm{O}-\mathrm{nBu})_{4}$ was added dropwise $\left(1 \mathrm{~mL} \cdot \mathrm{min}^{-1}\right)$ to the solution. Ice bath was applied to prevent the decomposition of $\mathrm{H}_{2} \mathrm{O}_{2}$ caused by the exothermic hydrolysis procedure. The addition of $\mathrm{Ti}(\mathrm{O}-\mathrm{nBu})_{4}$ to the solution resulted in the change of its color to yellow then orange, and finally to dark orange indicating the formation of peroxo-titanium complexes [136]. The solution was aged for additional 10 minutes during magnetic stirring, then the bottom inorganic phase was isolated by a separating funnel after 60 minutes of phase separation time. The sol was aged for $168 \mathrm{~h}$ at $40^{\circ} \mathrm{C}$ then the temperature was raised for 48 $\mathrm{h}$ to $55^{\circ} \mathrm{C}$, since $40^{\circ} \mathrm{C}$ was not sufficient to initiate the crystallization process in the presence of $\mathrm{H}_{2} \mathrm{O}_{2}$, due to the high stability of peroxo-titanium complex [136]. In the latter step the temperature had to be kept below $60^{\circ} \mathrm{C}$ since above this temperature the formation of anatase occurs [183]. The suspension was dried at $40{ }^{\circ} \mathrm{C}$ in a drying oven then ground in an agate mortar. As-prepared materials were washed 4 times by centrifugation using MQ water. After the purification, the obtained powders were dried at $40{ }^{\circ} \mathrm{C}$ and ground again in an agate mortar prior the photocatalytic experiments.

For the fabrication of anatase and amorphous phase titanium dioxides via oxygen rich modification the synthesis method of the Rutile-H2 sample was applied. The same steps were taken until the point of phase separation and after that, the synthesis was modified marginally. According to Tang et al. increasing the $\mathrm{pH}$ above 2 results in the formation of anatase phase [183], consequently, the $\mathrm{pH}$ was set to 3 with proper amount of $2 \mathrm{M} \mathrm{NaOH}$. By the addition of $\mathrm{NaOH}$ it was observed, that the crystallization process commenced in less than 24 hours (much sooner than at the original $\mathrm{pH}$ value), thus the sol was aged for $24 \mathrm{~h}$ at $40{ }^{\circ} \mathrm{C}$, then for $24 \mathrm{~h}$ at $55^{\circ} \mathrm{C}$ (sample denoted as Amorphous-H2) or $70{ }^{\circ} \mathrm{C}$ (sample denoted as Anatase-H2). Finally, same as before, the as-prepared suspensions were dried at $40{ }^{\circ} \mathrm{C}$ then washed 4 times with MQ water by centrifugation, dried again, then ground in an agate mortar prior further experiments.

For the preparation of titanium dioxide hollow structures carbon spheres templates were synthesized as the first step. In a Teflon ${ }^{\circledR}$-lined stainless-steel autoclave $\left(\mathrm{V}_{\text {total }}=623\right.$ $\mathrm{mL}$ ) $180.7 \mathrm{~mL} 0.15 \mathrm{M}$ sucrose solution was prepared, and the $\mathrm{pH}$ was set to 12 using $2 \mathrm{M}$ 
sodium hydroxide $\left(\mathrm{V}_{\text {fill }} / \mathrm{V}_{\text {total }}=29 \%\right)$. Then, the hydrothermal treatment of CSs was carried out by placing the autoclave in a drying oven at $180^{\circ} \mathrm{C}$ for $12 \mathrm{~h}$. Subsequently, the brownishblack product was collected as soon as the autoclave cooled down to room temperature, then, the samples were centrifuged $(4400 \mathrm{rpm}, 120 \mathrm{~min})$. To remove the residual organic contaminants - formed during the hydrothermal synthesis - either vacuum filtration, membrane filtration or centrifugation was applied to determine the best purification technique. In the first case a vacuum filter apparatus was used (equipped with a Millipore, Durapore PVDF membrane, $47 \mathrm{~mm}, 0.1 \mu \mathrm{m}$ ) and the CS suspension was washed with MQ water, then either with ethanol or acetone to determine the possible differences in the characteristics of the resulting CSs. For the membrane filtration $250 \mathrm{~mL}$ of the CS suspension was filtered through a polytetrafluoroethylene (PTFE) ultrafilter membrane in a batch-stirred membrane reactor (Millipore, XFUF07601) under vigorous magnetic stirring until the volume reduction ratio (VRR) was 5 (200 mL permeate, and $50 \mathrm{~mL}$ concentrate were produced). Then, the concentrate was purified by various cycles of acetone or MQ water addition, followed by repeated filtrations. One cycle meant the addition of $200 \mathrm{~mL}$ acetone or MQ water and the subsequent filtration, until reaching the desired VRR=5 value. The lowest degree of purification was carried out by the utilization of 1 acetone and $1 \mathrm{MQ}$ cycle, a standard purification by 3 acetone and 1 MQ cycles, meanwhile the most purified CS was prepared by 5 acetone and 2 MQ water cycles, respectively. Total amounts of the employed acetone and MQ water were $100-500 \mathrm{~mL} \cdot \mathrm{g}^{-1} \mathrm{CS}$ and $100-200 \mathrm{~mL} \cdot \mathrm{g}^{-1} \mathrm{CS}$, respectively. Lastly, in the case of centrifugation (which proved to be the most feasible method) the CSs were washed in three cycles using solely acetone. The rate of centrifugation was $13400 \mathrm{rpm}$ and the total amount of acetone was $80 \mathrm{~mL} \cdot \mathrm{g}^{-1} \mathrm{CS}$. At the end of each purification method the solid product was dried in air at $40{ }^{\circ} \mathrm{C}$ and was ground in agate mortar. The samples were named as follows: CS-t-pH, where ' $\mathrm{t}$ ' is the time of hydrothermal treatment, ' $\mathrm{pH}$ ' is the $\mathrm{pH}$ of the starting sucrose solution.

After the fabrication of CS templates, the synthesis method of Rutile-H2 was applied for the morphological modification of $\mathrm{TiO}_{2}-\mathrm{s}$. For a typical synthesis the $\mathrm{TiO}_{2}$ coating was formed by using $3.5 \mathrm{~mL}$ MQ water, $1.3 \mathrm{~mL} \mathrm{H} \mathrm{H}_{2}, 1.58 \mathrm{~mL} \mathrm{HCl}$ and $\left.2.14 \mathrm{~mL} \mathrm{Ti(O-nBu}\right)_{4}$. During the separate preparation of $\mathrm{TiO}_{2}$ coating, the same steps were taken until the point of phase separation, and after that, the synthesis was carried out as follows. The coating process took place by adding $1.9 \mathrm{~g}$ of the previously prepared CSs to the bottom inorganic phase (containing the titania) which was then sonicated for 10 minutes. The as-prepared suspension 
was aged for $48 \mathrm{~h}$ at $55{ }^{\circ} \mathrm{C}$ to initiate the crystallization process resulting the $\mathrm{TiO}_{2}-\mathrm{CS}$ composites. Afterwards, CSs were eliminated by calcination using either muffle furnace (Nabertherm B 180 type) without additional air supply or a tube furnace (Thermolyne 21100 type) under continuous air supply $\left(0.5 \mathrm{dm}^{3} \cdot \mathrm{min}^{-1}\right)$ with a heating rate of $5{ }^{\circ} \mathrm{C} \cdot \mathrm{min}^{-1}$ for $4 \mathrm{~h}$ at $400{ }^{\circ} \mathrm{C}$ resulting the $\mathrm{TiO}_{2}$-HSs (based on TG-DTG measurements applying $\sim 400{ }^{\circ} \mathrm{C}$ was sufficient to remove the CS templates [73]). The names of the $\mathrm{TiO}_{2}$ samples will be the following: 'H2_HS_X', where H2 refers to our previous 'Rutile-H2' $\mathrm{TiO}_{2}$ whose synthesis method was used for the coating process; HS refers to hollow structures, and X is the number indicating the synthesis conditions.

For the synthesis of noble metal-modified titanium dioxides, the carbon spheres purified by centrifugation (using either ethanol or acetone as solvent) were applied as templates. The preparation of the $\mathrm{TiO}_{2}$ coating was based on the publication of Ao et al. [155]. $0.1 \mathrm{~g}$ CS was added to $20 \mathrm{~mL}$ absolute ethanol in a beaker during vigorous magnetic stirring, to which $1 \mathrm{~mL}$ Ti(IV) butoxide was added dropwise with a constant speed of 1 $\mathrm{mL} \cdot \mathrm{min}^{-1}$. Then, the beaker was covered, and the suspension was stirred for 4 hours. After the formation of the coating, the samples were dried, and ultimately the CSs were eliminated by calcination in the Thermolyne 21100 type tube furnace with constant air supply (0.5 $\mathrm{dm}^{3} \cdot \mathrm{min}^{-1}$ ) at either 500 or $800{ }^{\circ} \mathrm{C}$ applying $5^{\circ} \mathrm{C} \cdot \mathrm{min}^{-1}$ heating speed, resulting in crystalline $\mathrm{TiO}_{2}$-HSs. Subsequently, gold or platinum nanoparticles were deposited onto the surface of $\mathrm{TiO}_{2}$-HSs at $0.25 \mathrm{wt} \%$ using either $1.6 \mathrm{~mL} \mathrm{HAuCl}_{4} \cdot 4 \mathrm{H}_{2} \mathrm{O}$ or $1.3 \mathrm{~mL} \mathrm{H}_{2} \mathrm{PtCl}_{6}$, respectively, for the modification of $800 \mathrm{mg} \mathrm{TiO}$-HSs. The photocatalyst was added to $87 \mathrm{~mL} \mathrm{MQ}$ water, to which $12.5 \mathrm{~mL}$ trisodium citrate was added. For the chemical reduction of noble metals 2 mL precooled $\mathrm{NaBH}_{4}(0.15 \mathrm{M})$ was applied, and the suspension was stirred for 30 min then purified via centrifugation 3 times using MQ water. Finally, the samples were dried in air at $40{ }^{\circ} \mathrm{C}$ and were ground in an agate mortar. The as-prepared samples were named based on the following: $\mathrm{TiO}_{2}-\mathrm{HS}^{\mathrm{x}}{ }_{\mathrm{y}} \mathrm{z}$, where 'HS' stands for hollow spheres, ' $\mathrm{x}$ ' is the solvent which was used for the purification of the carbon spheres ('Ac' for acetone and 'EtOH' for ethanol), and ' $y$ ' is the calcination temperature which was used for both the elimination of carbon spheres and the crystallization of $\mathrm{TiO}_{2}$, and ' $\mathrm{z}$ ' is the deposited noble metal.

\subsection{Methods and instrumentation}

A Rigaku Miniflex II diffractometer was used for the X-ray diffraction (XRD) measurements with the following parameters: $\lambda_{\mathrm{Cu} \mathrm{K} \alpha}=0.15406 \mathrm{~nm}, 40 \mathrm{kV}$, and $30 \mathrm{~mA}, 20-$ 
$40\left(2 \theta^{\circ}\right)$ region. The average primary crystal size values were calculated using the Scherrer equation. The weight fraction of the rutile and anatase phases were estimated from the peak areas at $27.5\left(2 \theta^{\circ}\right)$ and $25.3\left(2 \theta^{\circ}\right)$, respectively.

Morphology of the samples was analyzed by a Hitachi S-4700 Type II scanning electron microscope (SEM) and a FEI TECNAI $G^{2} 20 X$-Twin type transmission electron microscope (TEM). The former was used to examine the general morphology, while the latter to observe the hollow structure and the presence of noble metals on the surface of the $\mathrm{TiO}_{2}$ samples. The average primary crystallite sizes were calculated by the Scherrer equation (11), where $\mathrm{K}$ is the shape factor (which depends on the crystallite type), $\lambda$ is the wavelength of the X-ray waves, $\beta$ s is the line broadening at half the maximum intensity in radian for the sample, $\beta_{0}$ is the instrumental broadening in radian (previously determined by using a silicon single crystal) and $\theta$ is the Bragg angle:

$$
d=\frac{K \times \lambda}{\left[\left(\beta_{S}-\beta_{0}\right) \times \cos \theta\right]}
$$

The weight fractions (W) of the crystal phases were determined from the peak areas of the anatase $\left(A_{A}\right)$, rutile $\left(A_{R}\right)$ and brookite $\left(A_{B}\right)$ peaks while $k_{A}$ and $k_{B}$ are correction factors [184].

$$
\begin{aligned}
& W_{A}=\frac{k_{A} \times A_{A}}{k_{A} \times A_{A}+A_{R}+k_{B} \times A_{B}} \\
& W_{R}=\frac{A_{R}}{k_{A} \times A_{A}+A_{R}+k_{B} \times A_{B}} \\
& W_{B}=\frac{k_{B} \times A_{B}}{k_{A} \times A_{A}+A_{R}+k_{B} \times A_{B}}
\end{aligned}
$$

The recorded images were utilized to determine the diameter and the circularity [185] of the spheres using the ImageJ software. The circularity (C) of the spheres was calculated based on the following equation:

$$
C=\frac{4 \pi A}{P^{2}}
$$

where $\mathrm{A}$ is the area and $\mathrm{P}$ is the perimeter of the projection of the spheres [185]. During SEM measurements the electron beam was produced using a cold field emission gun applying 10 $\mathrm{kV}$ acceleration voltage, while in the case of TEM $100 \mathrm{kV}$ was set.

A Jasco-V650 spectrophotometer with an integration sphere (ILV-724) was used for measuring the DR (diffuse reflectance) spectra of the samples $(\lambda=220-800 \mathrm{~nm})$. To obtain the band gap energy the reflectance data were converted to $F(A)$ values according to the Kubelka-Munk theory. The band gap was obtained from the plot of $[\mathrm{F}(\mathrm{A}) \mathrm{E}]^{1 / 2}$ versus energy 
of the exciting light $(\mathrm{E})$. In some cases the possible electron transitions were evaluated by plotting the $d R \cdot d \lambda^{-1}$ vs. $\lambda$, where $R$ is the reflectance and $\lambda$ is the wavelength [3].

Specific surface areas of the catalysts were determined by $\mathrm{N}_{2}$ adsorption at $77 \mathrm{~K}$, using a BELCAT-A device. The specific surface area was calculated via the BET method.

IR spectra were recorded by using a Bruker Equinox 55 spectrometer. Samples were ground with $\mathrm{KBr}$ pressed into thin pellets (thickness $\sim 0.3 \mathrm{~mm}$ ) and the spectra were recorded with a spectral resolution of $2 \mathrm{~cm}^{-1}$.

Raman spectra were taken by a Thermo Scientific DXR Raman microscope utilizing $532 \mathrm{~nm}$ laser irradiation.

Thermogravimetric analysis (Netzsch STA409 PC connected to a Pfeiffer QMS 200 mass spectrometer system) of the CSs was performed in oxygen flow $\left(40 \mathrm{~cm}^{3} \cdot \mathrm{min}^{-1}\right)$ with 5 ${ }^{\circ} \mathrm{C} \cdot \mathrm{min}^{-1}$ heating rate using $\sim 100 \mathrm{mg}$ sample.

XPS measurements were performed on a Specs Phoibos 150 MCD system employing a monochromatic Al-K $\alpha$ source $(1486.6 \mathrm{eV})$ at $14 \mathrm{kV}$ and $20 \mathrm{~mA}$, a hemispherical analyzer and charge neutralization device. Samples were fixed on a double-sided carbon tape and care was taken to ensure that the sample particles covered the tape. Experiments were performed by operating the X-ray source with a power of $200 \mathrm{~W}$, while the pressure in the analyzing chamber was in the range of $10^{-9}-10^{-10}$ mbar. The binding energy scale was charge referenced to the $\mathrm{C} 1 \mathrm{~s}$ at $284.6 \mathrm{eV}$. High resolution O1s and Ti2p spectra were obtained using analyzer pass energy of $20 \mathrm{eV}$ in steps of $0.05 \mathrm{eV}$ for analyzed samples. Analysis of the data was carried out with the Casa XPS software.

\subsection{Evaluation of photocatalytic activity}

The experiments were carried out in a double-walled glass vessel $(\mathrm{V}=100 \mathrm{~mL}$ ) which was surrounded either by four conventional energy saving compact fluorescence lamps (Düwi 25920/R7S, 24W) for the visible light measurements or 6 fluorescent tubes (Vilber-Lourmat T-6L UV-A, 6W) for the UV experiments. The light intensities - previously measured by iron(III) oxalate actinometry [100] - were IUv $=9.23 \pm 0.01 \times 10^{-6}$ einstein $\cdot \mathrm{L}^{-}$ ${ }^{1} \cdot \mathrm{s}^{-1}$ and IVIS $=1.07 \pm 0.03 \times 10^{-5}$ einstein $\cdot \mathrm{L}^{-1} \cdot \mathrm{s}^{-1}$ for the visible light and UV lamps, respectively. During the visible light illumination, the spectrum of the lamps was slightly modified by circulating $1 \mathrm{M}$ sodium-nitrite (Molar Chemicals, min. 99.13\%) aqueous solution in the thermostating jacket $\left(\mathrm{T}=25.0^{\circ} \mathrm{C}\right)$. The $\mathrm{NaNO}_{2}$ solution absorbs UV photons, 
therefore provides solely visible light irradiation for the suspension. The photoreactor settings and the emission spectra of the lamps are represented in Fig. 8.

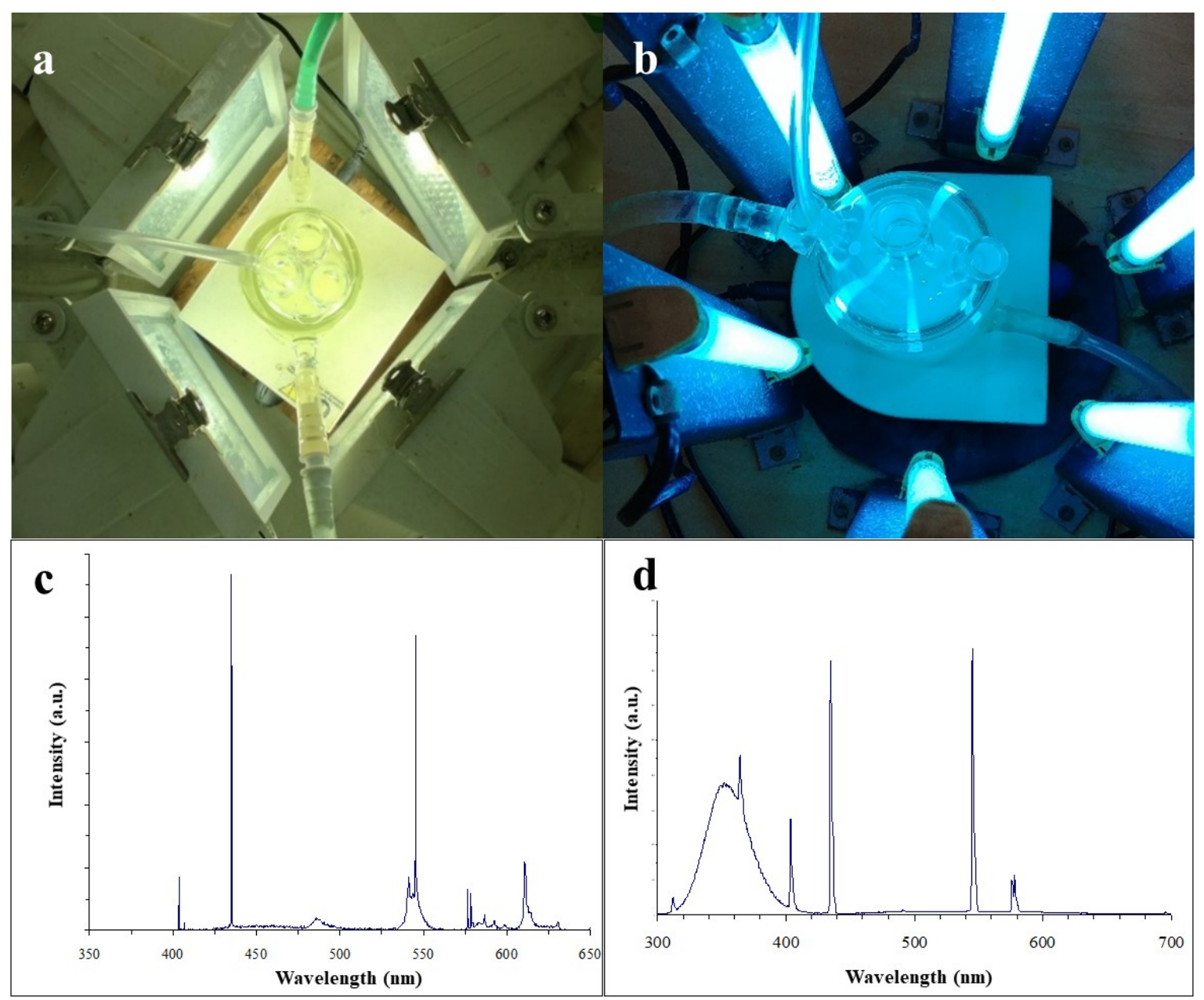

Figure 8 Reactor settings equipped with visible light-emitting lamps (a; by using $\mathrm{NaNO}_{2}$ cut-off solution), UV lamps (b) and their corresponding emission spectra (c, d).

During the tests, air was introduced to the reactor $\left(40 \mathrm{~L} \cdot \mathrm{h}^{-1}\right)$ to provide constant concentration of dissolved oxygen. The examined $\mathrm{TiO}_{2}$ samples were suspended in the solution of model contaminant in $1.0 \mathrm{~g} \cdot \mathrm{L}^{-1}$ concentration. Prior the photocatalytic experiments the suspensions were sonicated in dark for 10 minutes, then during the measurements they were vigorously stirred to ensure their proper mixing. The photocatalytic degradation reaction was initiated by switching on the lamps - after the suspensions were stirred in dark to reach adsorption/desorption equilibrium (10 mins for phenol and 30 mins for oxalic acid) - which was then followed by sampling at regular time intervals.

Changes in phenol concentration $(\mathrm{c} 0$, phenol $=0.1 \mathrm{mM})$ were measured by a Hitachi HPLC system equipped with a Lichrospher RP 18 column using methanol/water mixture (50:50) as eluent. It consisted of a Merck Hitachi L-7100 low-pressure pump equipped with 
a Merck-Hitachi L-4250 UV-Vis detector. Detection wavelength was set to the lower wavelength absorption maximum of phenol $\left(\lambda_{\text {detection }}=210 \mathrm{~nm}\right)$. Changes in oxalic acid concentration ( $\mathrm{C}_{0}$, oxalic acid $=1 \mathrm{mM}$ ) were measured by the same HPLC system equipped with a Grom-Resin ZH-type column using $19.3 \mathrm{mM}$ sulfuric acid as eluent ( $\lambda_{\text {detection }}=206 \mathrm{~nm}$ ).

Reusability of the most active $\mathrm{TiO}_{2}$-s of each chapter were examined by three consecutive phenol degradation measurements to determine the degree of the possible photocatalytic activity loss due to the repeated applications. 


\section{Results and discussion}

\subsection{Oxygen rich modification of rutile phase $\mathrm{TiO}_{2-\mathrm{s}}[186]$}

Prior my research work it was established in our research group, that non-doped commercial Aldrich rutile (AR) had notable photocatalytic activity during the photocatalytic degradation of phenol and the best disinfecting properties in comparison with many doped home-made and reference $\mathrm{TiO}_{2}$-s [68]. AR possessed this efficiency despite its large average primary particle size $(\sim 315 \mathrm{~nm})$ and very low specific surface area $\left(3 \mathrm{~m}^{2} \cdot \mathrm{g}^{-1}\right)$ despite the fact, that generally high specific surface area is preferred in photocatalytic processes. Based on this finding pure rutile phase $\mathrm{TiO}_{2}-\mathrm{s}$ with different particle sizes (and specific surface areas) were synthesized and characterized in one of our earlier publication [182]. Rutile as crystal phase was selected due to one of my goals being the fabrication of visible light active $\mathrm{TiO}_{2}-\mathrm{s}$, and rutile can absorb visible light to some extent thanks to its narrower band gap compared to anatase [55]. Consequently, from our previous work the sample denoted as Rutile-O (possessing the smallest primary particle size and highest photocatalytic activity) was selected as a base material for the oxygen rich modification (by applying different amounts of $\mathrm{H}_{2} \mathrm{O}_{2}$ during the synthesis) to further enhance its photocatalytic efficiency.

\subsubsection{Characterization}

The crystal phases of the reference and as-prepared $\mathrm{TiO}_{2}-\mathrm{s}$ were determined by $\mathrm{X}$ ray diffraction measurements (Fig. 9). The crystal phase distributions and the average primary particle sizes - estimated by the Scherrer equation - were presented in Table 1. The crystalline phase of the synthesized $\mathrm{TiO}_{2}-\mathrm{s}$ was rutile (>99 wt\%) and they had very small particle sizes $(\mathrm{D}=5.2-7.3 \mathrm{~nm})$. Aeroxide P25 contained $90 \mathrm{wt} \%$ anatase and $10 \mathrm{wt} \%$ rutile $\left(D_{\text {anatase }}=25.4 \mathrm{~nm}\right.$ and $\left.D_{\text {rutile }}=40 \mathrm{~nm}\right)$, while US-R.N. Rutile contained $>99 \mathrm{wt} \%$ rutile (D $=30 \mathrm{~nm}$ ). The specific surface areas of our own rutile titania varied within 178 and 285 $\mathrm{m}^{2} \cdot \mathrm{g}^{-1}$ (Table 1). Examining the results, it can be deduced, that applying hydrogen peroxide during the synthesis increased the specific surface area (from $178 \mathrm{~m}^{2} \cdot \mathrm{g}^{-1}$ to $237-285 \mathrm{~m}^{2} \cdot \mathrm{g}^{-1}$ ) compared to Rutile-O $\mathrm{TiO}_{2}$. 


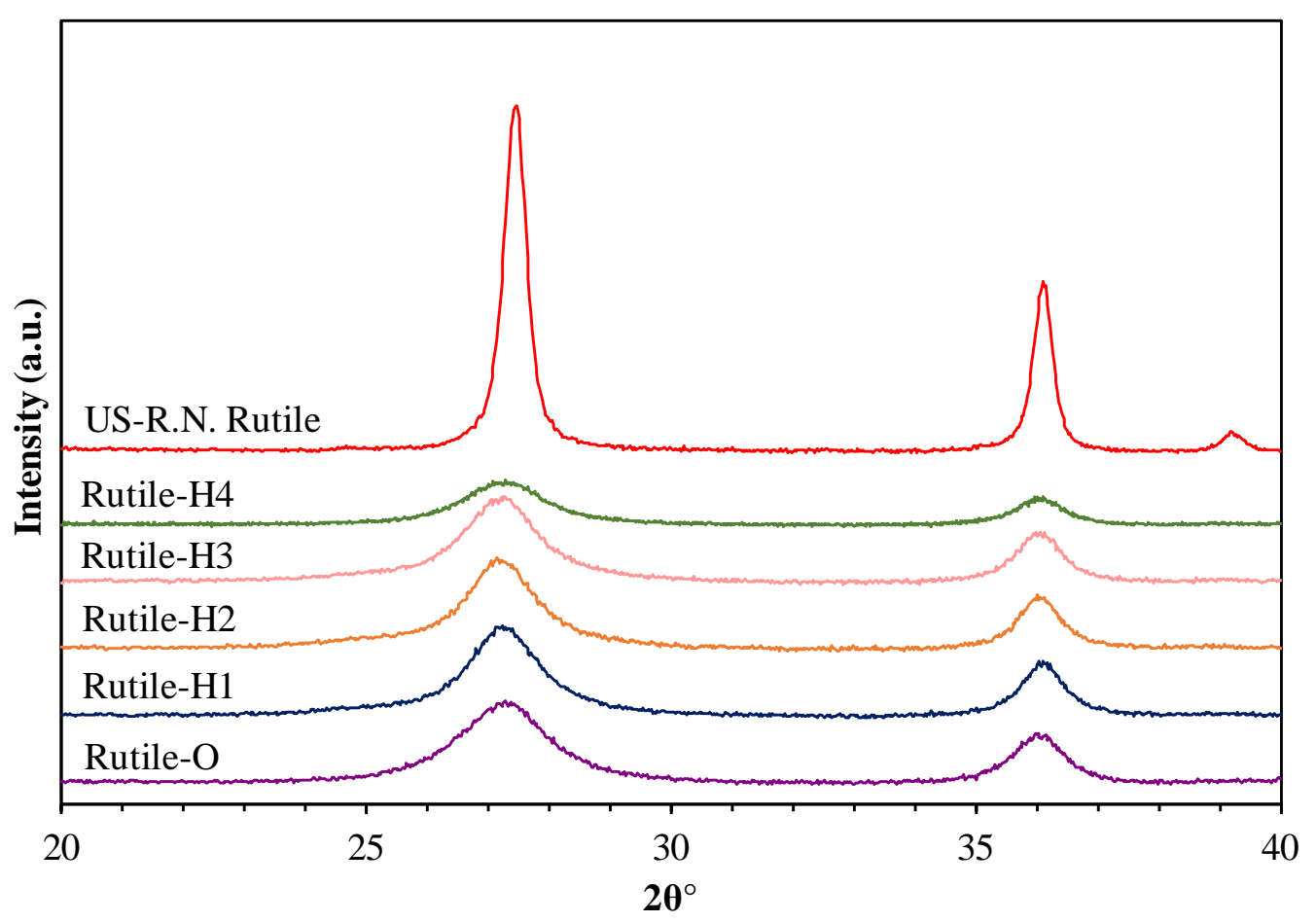

Figure $9 \mathrm{X}$-ray diffraction patterns of the investigated rutile phase $\mathrm{TiO}_{2}-\mathrm{s}$.

\begin{tabular}{|c|c|c|c|c|}
\hline \multirow{3}{*}{$\begin{array}{l}\text { Titanium- } \\
\text { dioxide }\end{array}$} & \multicolumn{4}{|c|}{ Phase composition } \\
\hline & \multicolumn{2}{|c|}{ Anatase } & \multicolumn{2}{|c|}{ Rutile } \\
\hline & wt $\%$ & $\begin{array}{c}\text { Particle size } \\
\text { (nm) }\end{array}$ & wt \% & $\begin{array}{c}\text { Particle size } \\
\text { (nm) }\end{array}$ \\
\hline Rutile-O & - & - & $>99$ & 5.2 \\
\hline Rutile-H1 & - & - & $>99$ & 7.3 \\
\hline Rutile-H2 & - & - & $>99$ & 7 \\
\hline Rutile-H3 & - & - & $>99$ & 6.8 \\
\hline Rutile-H4 & - & - & $>99$ & 6.9 \\
\hline Aldrich rutile & 4 & $315^{\text {TEM }}$ & 96 & $315^{\text {TEM }}$ \\
\hline Aeroxide P25 & 90 & 25.4 & 10 & 40 \\
\hline US-R.N. Rutile & - & - & $>99$ & 30 \\
\hline
\end{tabular}

Table 1 Phase composition and the average primer particle sizes of the investigated $\mathrm{TiO}_{2}-\mathrm{s}$.

The light absorption of the $\mathrm{TiO}_{2}-\mathrm{s}$ was determined by diffuse reflectance spectroscopy (DRS). As it can be seen in Fig. 10 at the top, the Rutile-H1, Rutile-H3 and Rutile-H4 samples possess greater light absorption in the visible light region compared to the Rutile-O, Rutile-H2 $\mathrm{TiO}_{2}$-s. The band gap energies obtained by the Kubelka-Munk method were 3.07, 3.00, 3.05, 2.91, 2.92 and 3.02, 3.11 for Rutile-O, Rutile-H1-Rutile-H4 
and reference photocatalysts US-R.N. Rutile and P25, respectively. Based on the results reported by Flak et al. [3], by plotting the first-order derivatives of the DR spectra as a function of wavelength, the dependence of the excitability from the wavelength can be determined more reliably. By applying such an approach, we found that Rutile- $\mathrm{H}_{2} \mathrm{TiO}_{2}$ had the highest visible light absorption (visible light excitability) properties as it can be seen in Fig. 10 at the bottom.
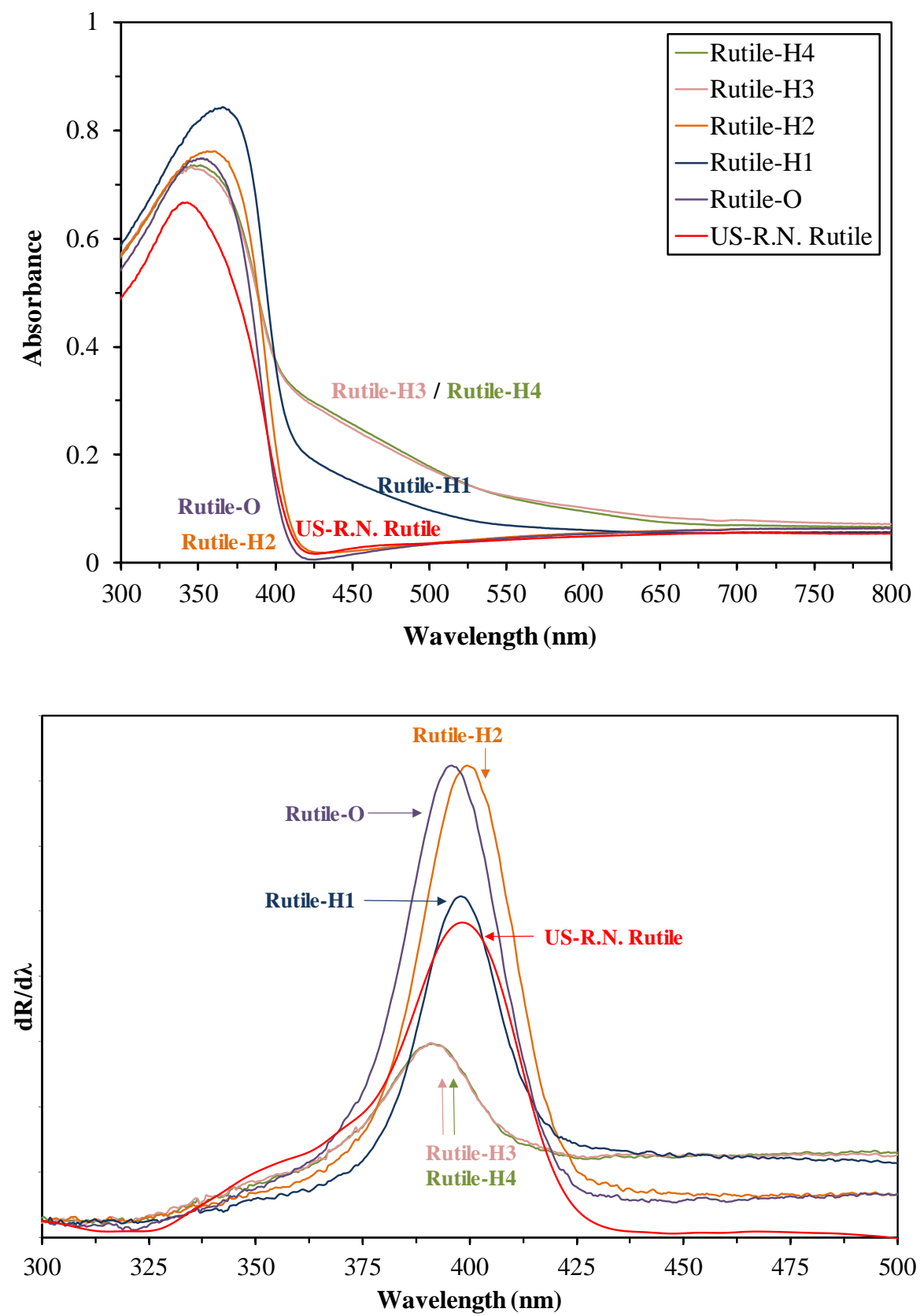

Figure $10 \mathrm{DR}$ spectra of the investigated $\mathrm{TiO}_{2}-\mathrm{s}$ (top) and their first order derivatives (bottom). 
Surface properties were determined by FT-IR spectroscopy. The FT-IR spectra (Fig. 11) showed, that our own $\mathrm{TiO}_{2}$-s had a broad band centered at $3400 \mathrm{~cm}^{-1}$, with a sharp band at $1630 \mathrm{~cm}^{-1}$ which can be attributed to the stretching and bending vibrations of the surface OH groups [187, 188]. Peaks at $1334 \mathrm{~cm}^{-1}, 1533 \mathrm{~cm}^{-1}$ and $2357 \mathrm{~cm}^{-1}$ represent bonds containing carbon $[187,189,190]$, which can be attributed either to residual contamination from the $\mathrm{TiO}_{2}$ precursor, or to the $\mathrm{CO}_{2}$ adsorbed on the surface. In our $\mathrm{TiO}_{2}-\mathrm{s}$ (Rutile-H1$\mathrm{H} 4)$, the IR absorption signal at $687 \mathrm{~cm}^{-1}$ corresponding to Ti-O-O stretching vibrations (representing peroxo groups) [128-130, 190] did not appear (and its intensity did not change with the $\mathrm{H}_{2} \mathrm{O}_{2}$ amount), meaning that either these $\mathrm{TiO}_{2}$-s did not have peroxo groups on the surface, or their quantity were below the threshold of detection of the IR spectrometer.

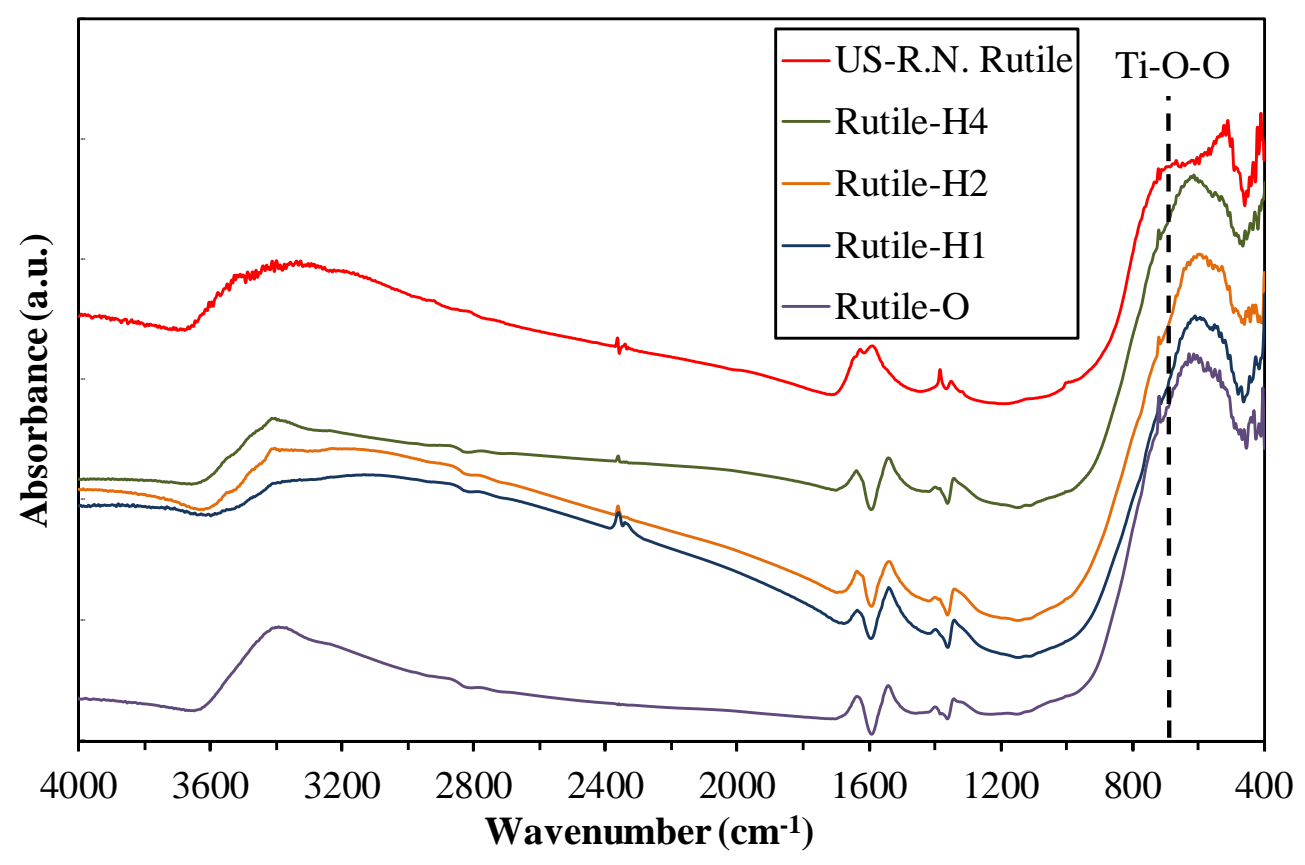

Figure 11 FT-IR spectra of the investigated $\mathrm{TiO}_{2}-\mathrm{S}$.

\subsubsection{Photocatalytic activity}

Following the morpho-structural characterization, the photocatalytic activities of the samples were investigated. As mentioned in the experimental section, the photocatalyst suspensions were left to be stirred in dark for $10 \mathrm{~min}$ to reach adsorption/desorption equilibrium. As expected, the changes in the concentration of phenol were negligible, (and within the range of experimental error of HPLC system), since phenol adsorbs poorly on 
titania surface [191]. The possibility of photolysis during the degradation of phenol was also excluded previously [69].

The phenol decay curves are presented in Fig. 12. Rutile-O had comparable photocatalytic performance to P25 (17\% of the phenol was degraded), while Rutile-H3 and Rutile-H4 $\mathrm{TiO}_{2}$-s had negligible photocatalytic activity. Our own Rutile-H2 $\mathrm{TiO}_{2}$ possessed by far the best photocatalytic efficiency compared to the other $\mathrm{TiO}_{2}-\mathrm{s}$ in the series $(26 \%$ of the phenol was degraded after 4 hours of irradiation), exceeding the photocatalytic activity of reference photocatalysts Aeroxide P25 and US-R.N. Rutile as well. The reusability of Rutile-H2 $\mathrm{TiO}_{2}$ was also determined by three consecutive phenol degradation measurements (the results are represented in the inset of Fig. 12). Results pointed out, that the photocatalyst had notable reusability, as it retained $98.4 \%$ of its initial photocatalytic efficiency after the measurements.

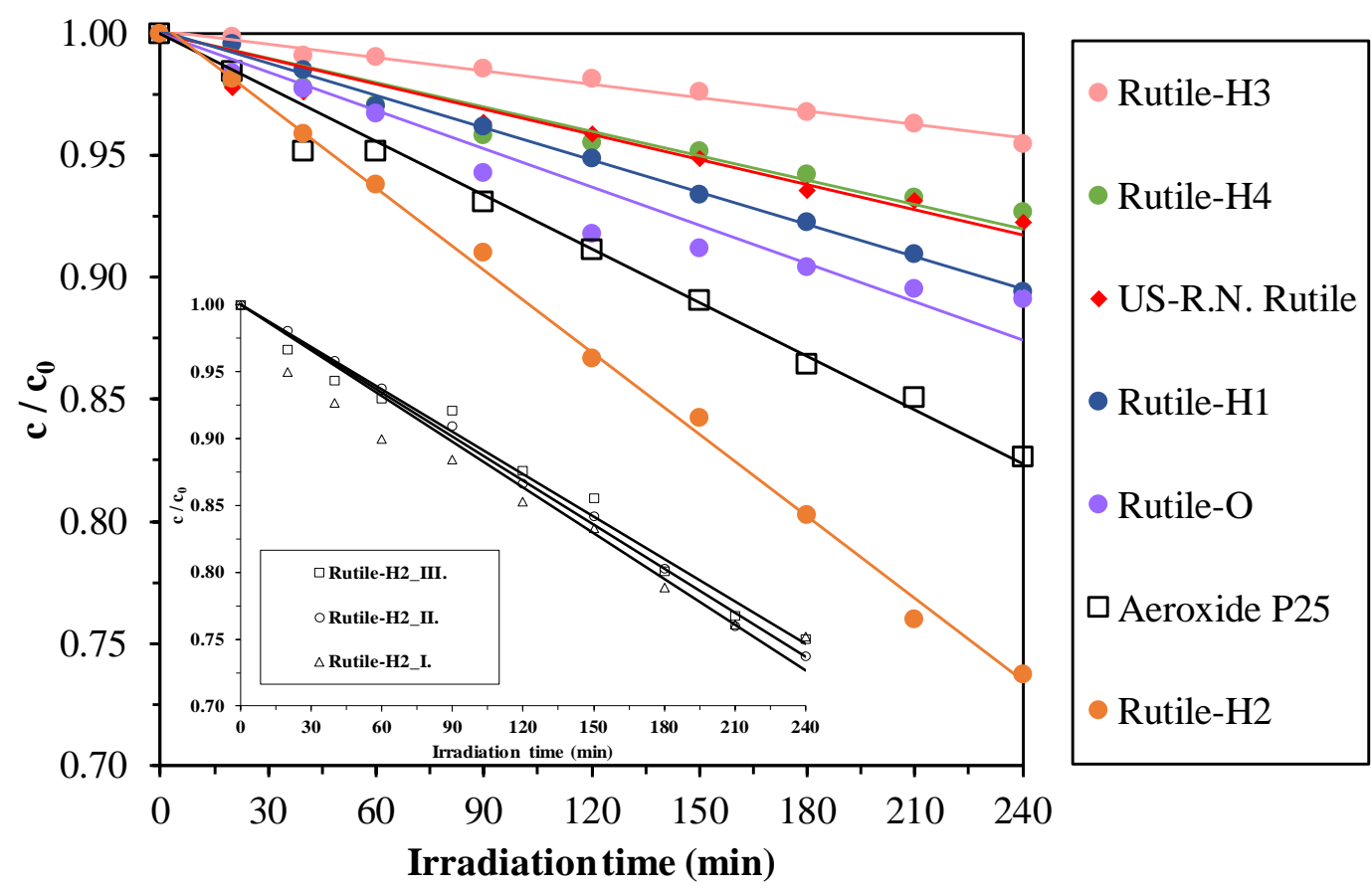

Figure 12 Decay curves of phenol under visible light irradiation. The reusability of Rutile-H2 $\mathrm{TiO}_{2}$ is represented in the inset.

\subsubsection{Further characterization and establishing connection between the results of} morpho-structural characterization and photocatalytic activity

From the acquired results, it can be assumed that Rutile-H2 may have different properties compared to the other $\mathrm{TiO}_{2}-\mathrm{s}$. To investigate the cause of the prominent 
photocatalytic activity, the measurements concerning the characterization of the photocatalysts were re-evaluated. XRD measurements could explain it in various ways. It is well-known, that the coexistence of anatase and rutile phase via their synergic effect can lead to increased photocatalytic performance [192]; however, in this case pure rutile phase titanium dioxides were obtained. Another explanation could be that higher specific surface area generally leads to higher photocatalytic activity [182], but in the series Rutile-H2 $\mathrm{TiO}_{2}$ had the second lowest value (apart from Rutile-O) and Rutile-H1, Rutile-H3, Rutile-H4 titania (with higher specific surface area) possessed lower photocatalytic activity. Therefore, the increase of photocatalytic activity in the case of Rutile- $\mathrm{H} 2 \mathrm{TiO}_{2}$ cannot be explained by its specific surface area. The next investigated parameter was the band gap values estimated from the DR spectra. It is generally accepted, that band gaps in the visible light region in most cases correspond to visible light activity [193]; however, as it was already stated in the previous section, all of the home-made $\mathrm{TiO}_{2}-\mathrm{s}$ had comparable band gaps and all in the visible light region (2.91-3.05 eV = 406.5-426 nm nm). Even though examining the first order derivatives of the DR spectra (Fig. 10 at the bottom), important differences can be seen, namely that the visible light absorption of Rutile- $\mathrm{H} 2 \mathrm{TiO}_{2}$ underwent a red shift which could be beneficial for the photocatalytic efficiency in the case of visible light irradiation [166]. Examining the descending part of the spectra (from right to left) the order of light absorption was in good accordance with the measured (decreasing) photocatalytic activities. Based on the results of the XRD and DRS measurements, it can be concluded, that the reason of the increased photocatalytic activity in the case of Rutile-H2 must be surface-related, therefore FT-IR measurements were performed. The IR spectra did not show any significant bands which could be attributed to the increased photocatalytic performance (e.g. notably increased quantity of lattice defects or hydroxyl groups [194]); moreover, the presence of peroxo groups could not be observed. It was deduced, that either the investigated titania samples did not have peroxo groups on the surface, or their quantity was below the detection limit of the IR spectrometer. This latter aspect was investigated via XPS measurements.

To identify $\mathrm{H}_{2} \mathrm{O}_{2}$ residues O1s spectra were analyzed (Fig. 13) in-detail for three of our samples and in terms of peroxo groups, commercial AR $\mathrm{TiO}_{2}$ was also investigated. The main component ( 80 - 93 at\%, Table 2) of the spectra was the lattice oxygen located at 530.0 - $530.2 \mathrm{eV}$ [194]. The second component (6 - 8.2 at\%, Table 2) was the surface $\mathrm{OH}$ groups, denoted as OH_O and detected at 531.0 - 531.4 eV [194]. Surface OH groups can be responsible for the hydrophilic character of the photocatalyst, which was already 
correlated with the activity (higher surface $\mathrm{OH}$ concentration $\rightarrow$ increased hydrophilicity $\rightarrow$ increased photoactivity towards the degradation of phenol). However, in our case the change in the concentration of OH_O was not significant and thus cannot be directly responsible for the observed photocatalytic activity [194]. Adsorbed water (denoted as $\mathrm{H}_{2} \mathrm{O} \_\mathrm{O}$ ) was also detected at $532.9 \mathrm{eV}$ [195], which can be associated with the hydrophilic character of the sample, similarly to the $\mathrm{OH} \_\mathrm{O}$. The amount of $\mathrm{H}_{2} \mathrm{O}$ fixed on the surface was $1.4-2.75$ at\% from the total oxygen content. Moreover, a low-binding energy oxygen was detected at 528.6 $\mathrm{eV}$, which belongs to surface oxygen defects and usually appears together with $\mathrm{Ti}^{3+}$ (in our case this was also detected, but not shown) [196]. The most important signal was identified at $532.0 \mathrm{eV}$, which was attributed to peroxo group originating from the $\mathrm{H}_{2} \mathrm{O}_{2}$. Named as oxygenated species, they were found in layered oxide electrodes applicable in lithium batteries [197].
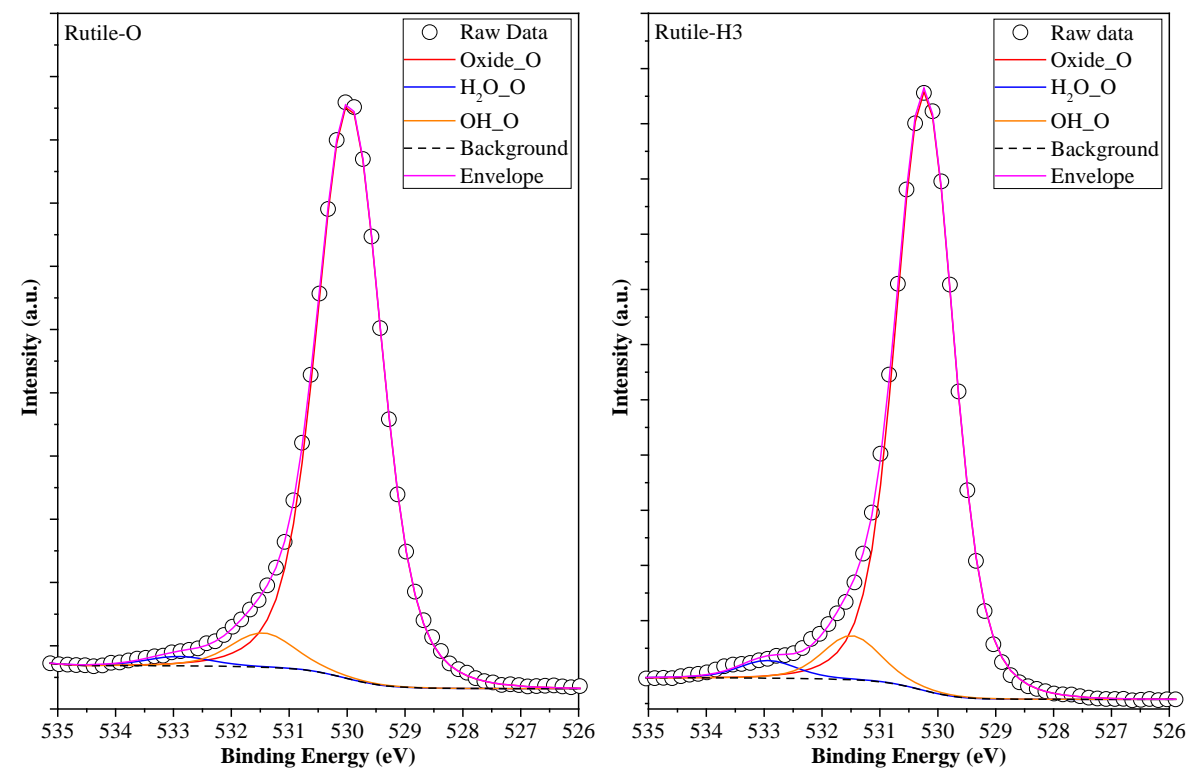

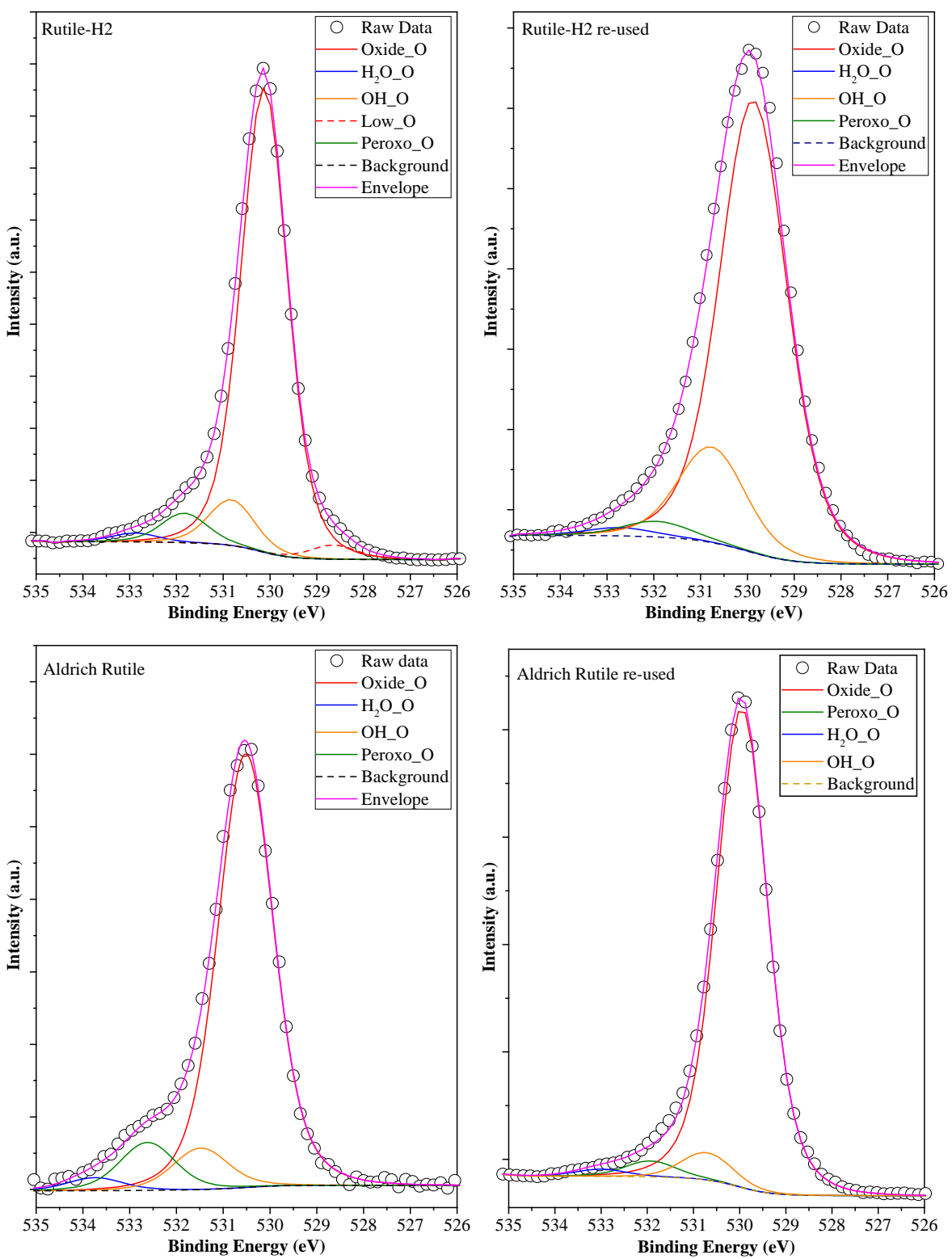

Figure 13 High-resolution O1s XPS spectra of Rutile-O, Rutile-H2, Rutile-H3 and reference AR. Samples Rutile-H2 and AR were re-used three times to investigate peroxo group stability.

\begin{tabular}{|c|c|c|c|c|}
\hline \multirow{2}{*}{ Species (at \%) } & \multicolumn{4}{|c|}{ Samples } \\
\cline { 2 - 5 } & Rutile-O & Rutile-H2 & Rutile-H3 & AR \\
\hline Oxide_O & 92.45 & 82.56 & 90.67 & 81.08 \\
\hline $\mathrm{H}_{2} \mathrm{O} \_O$ & 1.42 & 1.53 & 2.65 & 2.75 \\
\hline OH_O & 6.13 & 8.16 & 6.68 & 7.27 \\
\hline Low_O & - & 2.51 & - & - \\
\hline Peroxo_O & - & 5.24 & - & 8.9 \\
\hline
\end{tabular}

Table 2 The identified oxygen-containing species’ concentration in the investigated samples. 
The absence of $\mathrm{H}_{2} \mathrm{O}_{2}$ during the synthesis procedure resulted clearly in the absence of the signal at $532.0 \mathrm{eV}$. It was interesting that in the sample Rutile-H3 no peroxo group signal was detected, although, the $\mathrm{OH} \_\mathrm{O}$ component's maximum values shifts from sample to sample (three components fit with the presence of peroxo group was also attempted in case of Rutile-H3, with the same FWHM, Gaussian peak shape). This interesting behavior was also observed in the case of DR spectra, where the electron transition bands shifted towards the visible light region in the case of Rutile-H2, while the mentioned bands were located in the near UV region (samples Rutile-O and Rutile-H3). Peroxo_O was anchored on the surface of Rutile-H2 in 5.24 at\% which means 3493 ppm out of the total bulk mass (estimation based on atomic radii and weight, bulk density and an average of $7 \mathrm{~nm}$ diameter, sphere-like $\mathrm{TiO}_{2}$ particles), a rather low number. Despite this, Rutile-H2 was the most active sample in the visible light degradation of phenol (as well as in the degradation of Rhodamine $\mathrm{B}$ and formation of $\bullet \mathrm{OH}$ compared to Rutile-O, which was investigated complementarily in separate measurements [186]). It was deduced that the detected peroxo groups must be responsible for the enhanced photocatalytic activity.

The stability of the peroxo groups was also investigated (in the case of Rutile-H2 sample). After the measurements the catalyst preserved its activity after the applied re-usage period $(26.2 \%, 24.9 \%$ and $24.7 \%$ of phenol was degraded after the first, second and third reuse, respectively). The difference observed in the data can be attributed as experimental error. This was followed by the XPS measurement of the re-used catalyst. As it can be observed in the O1s spectrum, the main species' dominance was not changed (lattice oxygen - Oxide_O at 530.0 - 530.2 eV [194] and surface OH groups OH_O at 531.0 - 531.4 eV [194]) compared to catalyst before use (Fig. 13). The first major difference was the absence of low binding energy oxygen (previously at $528.6 \mathrm{eV}$ [196]), which was present in the original sample. This points out that locally the $\mathrm{Ti}^{3+}$ oxidized to $\mathrm{Ti}^{4+}$ (which was also observable in the Ti2p spectrum - not shown here), most probably due to the oxidation by the photogenerated holes [198]. Furthermore, it cannot be excluded that some of the amorphous matter crystallized at the surface of the catalyst, eliminating the previously mentioned $\mathrm{Ti}^{3+}$ which can be considered as crystal defects [198]. This change was accompanied by the slight increase of water-related oxygen, which is plausible, assuming that the $\mathrm{Ti}$ atoms whose coordination sphere is more likely occupied by hydroxyl groups $\left(\mathrm{Ti}^{4+}\right)$ can efficiently adsorb water as opposed to $\mathrm{Ti}^{3+}$ [199]. Most importantly, the amount of peroxo groups decreased to $\sim 54.5 \%$ of the initial quantity after the experiment, from 5.24 
to 2.83 at\% from total oxygen. As a basis of comparison, the stability of peroxo groups was also determined for commercial AR as well in the same way, and it was found that from the initial 8.9 at\% value their quantity decreased to 5.29 at\% (59.4\% of the initial amount). This shows that these groups may possess a relative stability over medium time interval. Also, it should be mentioned that the reusability experiment was carried out until total mineralization, exposing the catalyst to a further 24 hours of UV light ( $3 \cdot 24$ hours in total). However, the activity remained largely unchanged, most probably due to the disappearance of existing recombination centers $\left(\mathrm{Ti}^{3+}\right.$ - this specie is still considered with both positive and negative effects on the activity), which presumably compensated the loss of the peroxo groups.

It was very interesting that from our own samples, the mentioned peroxo groups were found only in the case of sample Rutile-H2. To elucidate this phenomenon, the literature concerning titanium peroxo complexes was thoroughly examined. Peroxo complexes of titanium evolve from mononuclear to binuclear complexes depending on the $\mathrm{pH}$. In our case the $\mathrm{pH}$ slowly increased as the crystallization of titania occurred (at $55^{\circ} \mathrm{C}$ ). Moreover, the starting molar ratio of $\mathrm{H}_{2} \mathrm{O}_{2}$ and $\mathrm{HCl}$ differs, making possible several scenarios [136, 137]:

- $\quad$ Starting point - hydrolysis $(\mathrm{pH}<1)$ :

$\mathrm{Ti}\left(\mathrm{H}_{2} \mathrm{O}\right)_{6}{ }^{4+}+\mathrm{H}_{2} \mathrm{O}_{2} \rightarrow \mathrm{TiO}_{2}\left(\mathrm{H}_{2} \mathrm{O}\right)_{4}{ }^{2+}+2 \mathrm{H}^{+}+2 \mathrm{H}_{2} \mathrm{O}$

- $\quad$ Deprotonation $(\mathrm{pH}=1-3)$ :

$\mathrm{TiO}_{2}\left(\mathrm{H}_{2} \mathrm{O}\right)_{4}{ }^{2+} \rightarrow \mathrm{TiO}_{2}(\mathrm{OH})\left(\mathrm{H}_{2} \mathrm{O}\right)_{3}{ }^{+}+\mathrm{H}^{+}$

- Mono-bi nuclear transformation $(\mathrm{pH}>3)$ :

$2 \mathrm{TiO}_{2}(\mathrm{OH})\left(\mathrm{H}_{2} \mathrm{O}\right)_{3}{ }^{+} \rightarrow \mathrm{Ti}_{2} \mathrm{O}_{5}(\mathrm{OH})^{+}\left(\mathrm{H}_{2} \mathrm{O}\right)_{6}$

Considering the above-listed steps, in the case of Rutile-H1 the amount of $\mathrm{H}^{+}$is too high, therefore no deprotonation is favored. Hence, when the polycondensation occurs (at higher $\mathrm{pH}$ values), the peroxo groups are not included in the newly formed crystals. When the amount of $\mathrm{H}_{2} \mathrm{O}_{2}$ was too high (in the case of Rutile-H3 and Rutile-H4), all the abovementioned steps occurred. In this case the possibility of two neighboring $\mathrm{Ti}$ atoms being included in peroxo complexes is very likely, and these entities (multi peroxo compounds) are unstable and decompose at $55^{\circ} \mathrm{C}$, leaving the system in the form of $\mathrm{O}_{2}$. When the amount of $\mathrm{H}_{2} \mathrm{O}_{2}$ was optimal, the obtained surface peroxo groups were stable, as on the Ti atom only one peroxo complex bridge was included with another Ti atom.

A plausible explanation for the increased photocatalytic efficiency caused by the peroxo groups could be following the steps listed below: 
- The photogenerated electrons can move freely on the surface of the catalyst, and in some cases interparticle electron transfer can also occur;

- When the surface does not contain any foreign atoms or specific surface groups, the electron has no preferred localization site;

- Peroxo groups, as they contain two oxygens, can manifest their electron attracting inductive effect. Accordingly, specific electron traps can be created, which can decrease the surface mobility of the electron;

- As the electrons are less mobile, their transfer to molecular oxygen is facilitated, resulting the well-known superoxide radical (which finally can yield $\bullet \mathrm{OH}$ radicals [62]), causing the enhancement of photocatalytic activity.

\subsection{Oxygen rich modification of amorphous and anatase phase $\mathrm{TiO}_{2}$-s} [200]

Following the successful anchoring of peroxo groups on the surface of the Rutile-O $\mathrm{TiO}_{2}$ and the enhancement of its photocatalytic activity, our aim was to investigate the possible beneficial effects of peroxo groups in the case of amorphous and anatase phase as well, since normally it is considered to be more active for photocatalytic applications [56]. The synthesis method of Rutile-O (which was based on the publication of Tang et al. [183]) is very sensitive for the concentration of acid: both lower and higher acid concentration can lead to the formation of anatase phase, which was reinforced by Cai et al. as well [138]. Consequently, during the synthesis of the following $\mathrm{TiO}_{2}-\mathrm{s}$ the $\mathrm{pH}$ was set accordingly to obtain amorphous and anatase phase $\mathrm{TiO}_{2}-\mathrm{s}$ with the aim of further enhancing their optical properties and photocatalytic activity.

\subsubsection{Characterization}

Following the synthesis of the as-described photocatalysts, firstly, the crystal phases of the $\mathrm{TiO}_{2}$-s were identified (Fig. 14) and the mean crystallite sizes (when it was lower than $100 \mathrm{~nm}$ ) were calculated using the Scherrer equation (Table 3). It was found that Aldrich anatase (AA) contained only anatase $(\mathrm{D}=85 \mathrm{~nm}$ ), Aldrich rutile (AR) contained mainly (96 wt\%) rutile ( $\mathrm{D} \sim 315 \mathrm{~nm}$, determined from TEM micrographs [69]) and a small amount of anatase (4 wt\%), while Aeroxide P25 (P25) - similarly to section 5.1.1. - contained $90 \mathrm{wt} \%$ anatase $(\mathrm{D}=25.4 \mathrm{~nm})$ and $10 \mathrm{wt} \%$ rutile $(\mathrm{D}=40 \mathrm{~nm})$. Rutile-H2 contained only rutile $(\mathrm{D}=$ $7 \mathrm{~nm}$ ), Amorphous-H2 $\mathrm{TiO}_{2}$ was almost completely amorphous, while the crystal phase of 

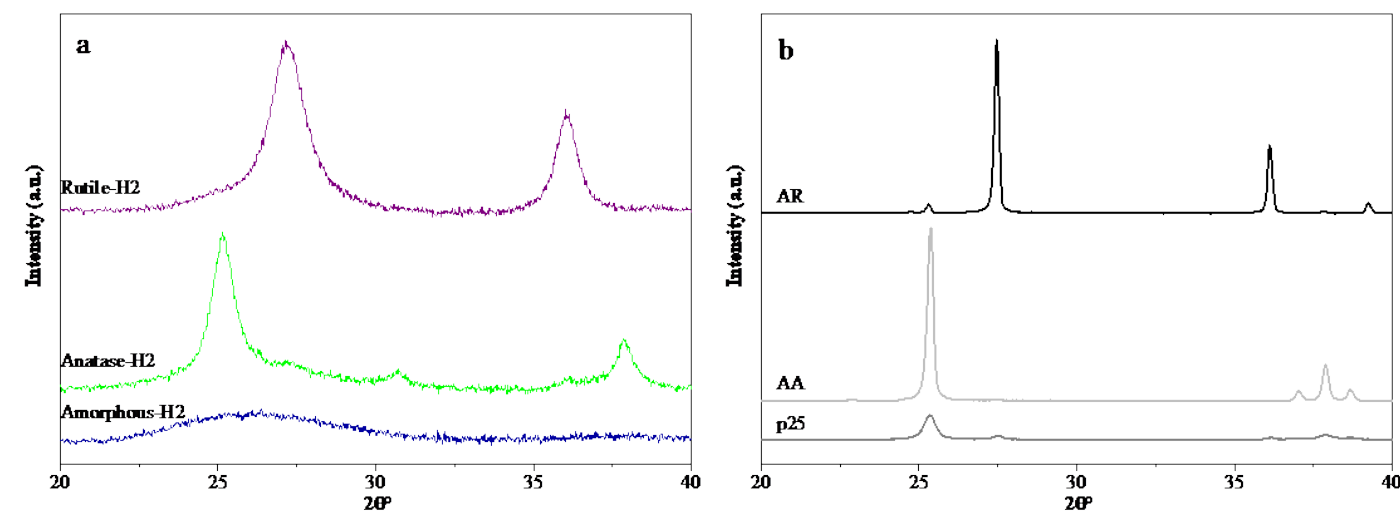

Figure $14 \mathrm{X}$-ray diffraction patterns of the investigated home-made (a) and reference (b) $\mathrm{TiO}_{2}-\mathrm{s}$.

\begin{tabular}{|c|c|c|c|c|c|c|c|}
\hline \multirow{3}{*}{$\begin{array}{l}\text { Titanium } \\
\text { dioxide }\end{array}$} & \multicolumn{7}{|c|}{ Phase composition } \\
\hline & \multicolumn{3}{|c|}{ Anatase } & \multicolumn{2}{|c|}{ Rutile } & \multicolumn{2}{|c|}{ Brookite } \\
\hline & $w t \%$ & \multicolumn{2}{|c|}{$\begin{array}{c}\text { Particle } \\
\text { size }(\mathrm{nm})\end{array}$} & wt $\%$ & $\begin{array}{c}\text { Particle } \\
\text { size }(\mathbf{n m})\end{array}$ & wt \% & $\begin{array}{c}\text { Particle } \\
\text { size }(\mathrm{nm})\end{array}$ \\
\hline Amorphous-H2 & - & \multicolumn{2}{|r|}{-} & - & - & - & - \\
\hline Anatase-H2 & 76 & \multicolumn{2}{|c|}{10.9} & 17 & 8.7 & 7 & 27.5 \\
\hline Rutile-H2 & - & \multicolumn{2}{|r|}{ - } & $>99$ & 7 & - & - \\
\hline $\mathrm{AR}$ & 4 & \multicolumn{2}{|c|}{$315^{\text {TEM }}$} & 96 & $315^{\text {TEM }}$ & - & - \\
\hline AA & 100 & \multicolumn{2}{|c|}{85} & - & - & - & - \\
\hline P25 & 90 & \multicolumn{2}{|c|}{25.4} & 10 & 40 & - & - \\
\hline $\begin{array}{l}\text { Titanium } \\
\text { dioxide }\end{array}$ & \multicolumn{2}{|c|}{$\begin{array}{c}\text { Specific } \\
\text { surface area } \\
\left(\mathrm{m}^{2} \mathrm{~g}^{-1}\right) \\
\end{array}$} & \multicolumn{2}{|c|}{ Band gap (eV) } & $\begin{array}{c}\mathbf{r}_{\text {0,phenol }} \\
\left(10^{-10} \mathrm{M} \mathrm{s}^{-1}\right)\end{array}$ & \multicolumn{2}{|c|}{$\begin{array}{c}\mathrm{r}_{0, \text { phenol }} \\
\left(10^{-12} \mathrm{M} \mathrm{m}^{-2} \mathrm{~s}^{-1}\right) \\
\text { surface normalized }\end{array}$} \\
\hline Amorphous-H2 & \multicolumn{2}{|c|}{120} & \multicolumn{2}{|c|}{2.34} & 51.3 & \multicolumn{2}{|c|}{42.7} \\
\hline Anatase-H2 & \multicolumn{2}{|c|}{176} & \multicolumn{2}{|c|}{2.29} & 31.1 & \multicolumn{2}{|c|}{17.7} \\
\hline Rutile-H2 & \multicolumn{2}{|c|}{237} & \multicolumn{2}{|c|}{3.11} & 18.3 & \multicolumn{2}{|c|}{7.7} \\
\hline $\mathrm{AR}$ & \multicolumn{2}{|l|}{3} & \multicolumn{2}{|c|}{2.91} & 38.4 & \multicolumn{2}{|c|}{1280.3} \\
\hline AA & \multicolumn{2}{|c|}{$<10$} & \multicolumn{2}{|c|}{3.26} & 6.2 & \multicolumn{2}{|c|}{68.5} \\
\hline P25 & \multicolumn{2}{|l|}{49} & \multicolumn{2}{|c|}{3.11} & 12.3 & \multicolumn{2}{|c|}{25.0} \\
\hline
\end{tabular}

Table 3 Phase composition, average primer particle sizes, band gaps and specific surface areas of the investigated $\mathrm{TiO}_{2}$-s. 
Anatase-H2 $\mathrm{TiO}_{2}$ contained mainly anatase (76 wt\%, D=10.9 nm) and non-negligible amounts of rutile ( $17 \mathrm{wt} \%, \mathrm{D}=8.7 \mathrm{~nm}$ ) and brookite ( $\mathrm{wt} \%, \mathrm{D}=27.5 \mathrm{~nm}$ ) as well. Rutile is generally more active in the case of visible light excitation [201, 202], still, anatase is considered to be more active for photocatalytic applications [56]. There are some instances in the literature, where mixtures of brookite with anatase and rutile proved to be highly photoactive, because of the presence of junctions among different polymorphic $\mathrm{TiO}_{2}$ phases which enhanced the separation of photogenerated electron-hole pairs [53]. It is well-known that synergistic effect between anatase and rutile phase can occur leading to reduced recombination rate of photogenerated charge carriers [192]. Moreover, amorphous $\mathrm{TiO}_{2}$ generally known nearly inactive due to the facilitated recombination of photogenerated electrons, although in some rare instances amorphous $\mathrm{TiO}_{2}$ was observed to be more active than crystalline $\mathrm{TiO}_{2}$ [130]. As it was presented until now, different crystal phases and amorphous material were also present in the investigated samples. Therefore, the next step was to investigate their optical properties to gain insights concerning their band-structure.

Light absorption properties of the investigated $\mathrm{TiO}_{2}$-s were characterized by DRS measurements (Fig. 15) and band gap values (Table 3) were calculated by using the Kubelka-Munk method [203].

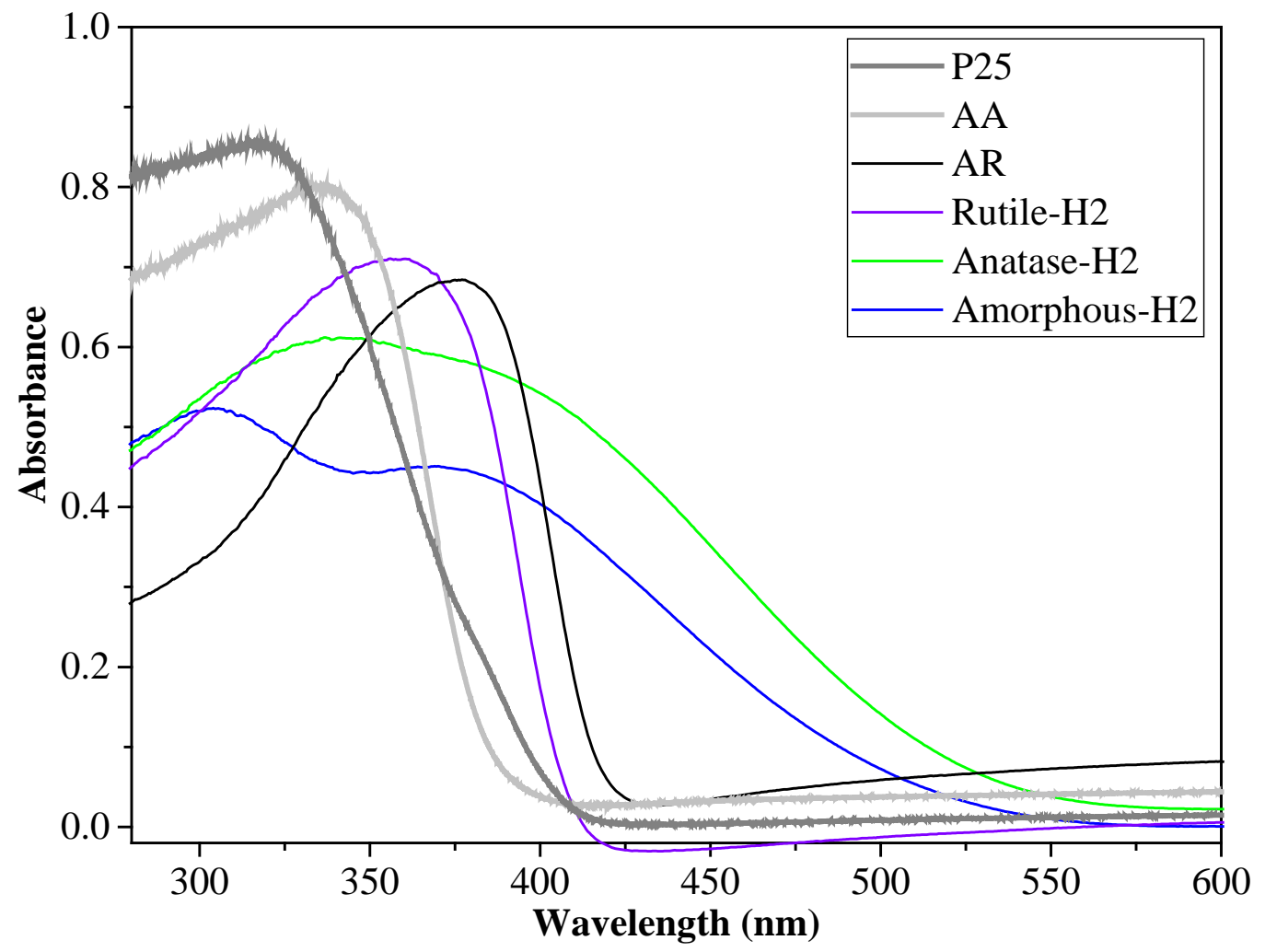

Figure 15 DR spectra of the investigated $\mathrm{TiO}_{2}-\mathrm{S}$. 
In the case of AR and Rutile-H2 slight absorption in the visible light region was detected, whereas as expected, reference AA and P25 titania possessed insignificant visible light absorption properties. Most importantly, results pointed out that self-made Amorphous-H2 and Anatase-H2 titania had greatly enhanced visible light absorption, (a redshift of 131 and $143 \mathrm{~nm}$ was observed, respectively, compared to the Rutile-H2 photocatalyst, which was synthesized without the modification of $\mathrm{pH}$ ) which is in good accordance with the yellow color of the catalysts. The first-order derivatives of DR spectra was plotted as a function of wavelength to determine the visible light excitability properties more reliably [3] (Fig. 16). By applying such an approach, it was found, that the excitability of the latter two self-made titania extended even past the $\sim 550 \mathrm{~nm}$ region, which may be a sign of a color center present (e.g. $\mathrm{Ti}^{3+}$ ) in very low concentrations. Furthermore, in sample Amorphous-H2 two electrontransition bands were observed in the derivative spectrum, one being in the visible (as already detailed above), while the other one is in the UV region, at $325 \mathrm{~nm}$.

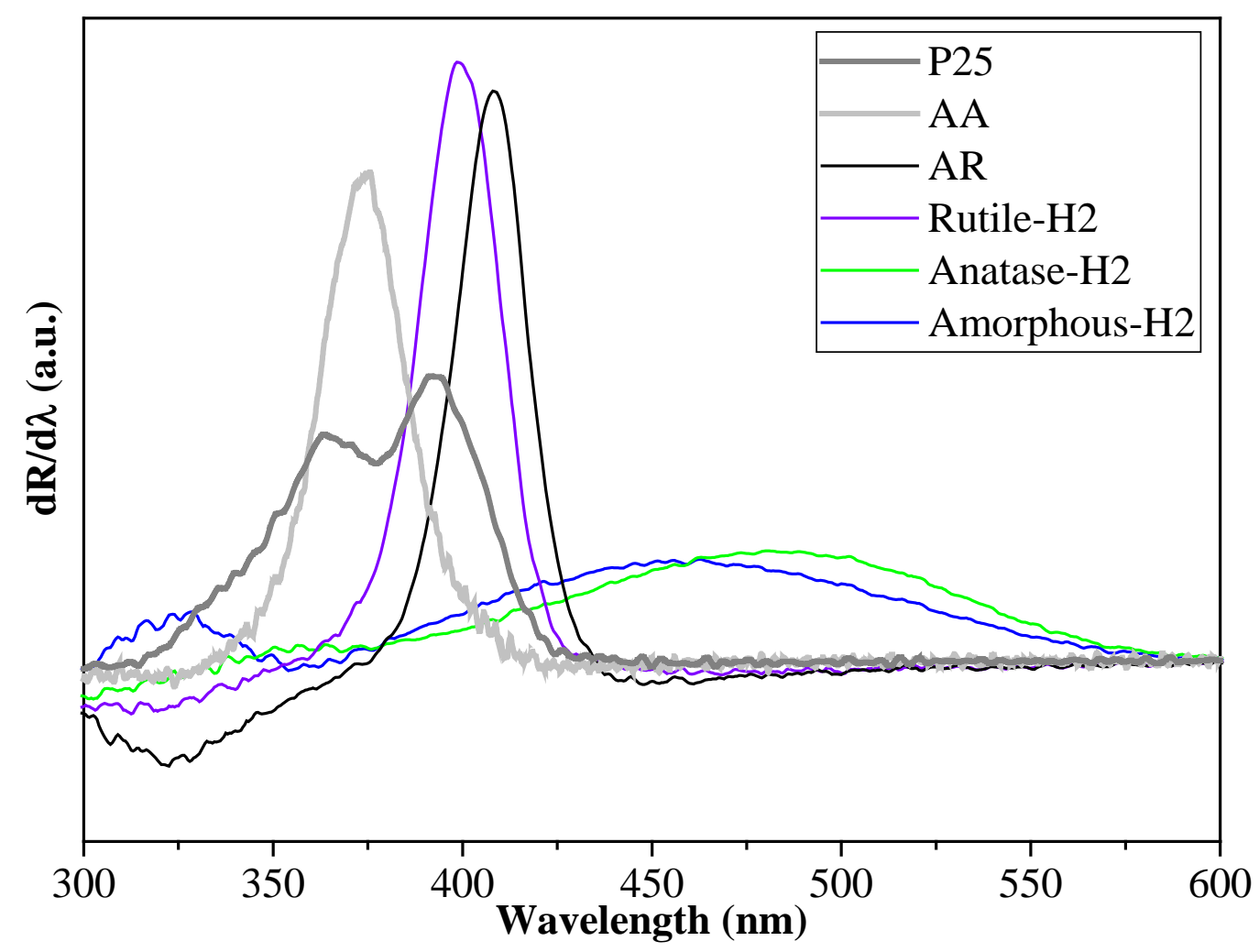

Figure 16 First order derivative DR spectra of the investigated $\mathrm{TiO}_{2}-\mathrm{s}$.

The cause of this peculiar peak and the wide visible light absorption was further investigated. There are numerous instances in the literature in which by applying different approaches (e.g. doping, deposition of noble metals) successful enhancement of visible light excitability 
was observed which corresponded well with the resulting photocatalytic efficiency [89, 166, 186, 204]. Presumably, the greatly enhanced visible light excitability of Amorphous-H2 and Anatase-H2 peroxo-titania will be beneficial for the photocatalytic efficiency. However, as all the samples are $\mathrm{TiO}_{2}-\mathrm{s}$ and no doping sources were added, the key to the structure of the materials once again was expected to be found on the surface of these materials. For this, and for the further characterization of the amorphous Amorphous-H2 sample FT-IR and Raman measurements were carried out.

The results of the FT-IR spectroscopy measurements are shown in Fig. 17 in the case of Amorphous-H2 and Anatase-H2 samples. Compared to Rutile-H2 $\mathrm{TiO}_{2}$, similarly, the broad band centered at $3400 \mathrm{~cm}^{-1}$ and the sharp band at $1630 \mathrm{~cm}^{-1}$ can be detected, which represent the stretching and bending vibrations of surface $\mathrm{OH}$ groups $[187,188]$, and the small peak at $2357 \mathrm{~cm}^{-1}$ representing bonds containing carbon [187, 189, 190] can be attributed either to adsorbed $\mathrm{CO}_{2}$ or residual contamination from the $\mathrm{TiO}_{2}$ precursor. At 900 $\mathrm{cm}^{-1}$ a new peak was observed, which can be attributed either to free or complexed -O-Ovibrations $[190,205]$ or the vibration of Ti-O bonds within the triangular peroxy titanyl group [189, 206, 207]. Most importantly, in the case of Amorphous-H2 sample, Ti-O-O stretching vibrations (representing peroxo groups) [128-130, 190] could be detected, in contrast with Rutile-H2 (and Anatase-H2) titania, where it was deduced, that the quantity of the peroxo groups was under the threshold of detection of the IR spectrometer and it was only observable by the more sensitive XPS measurements. These apparent differences could be crucial regarding the photocatalytic efficiencies of the investigated $\mathrm{TiO}_{2}$-s. 


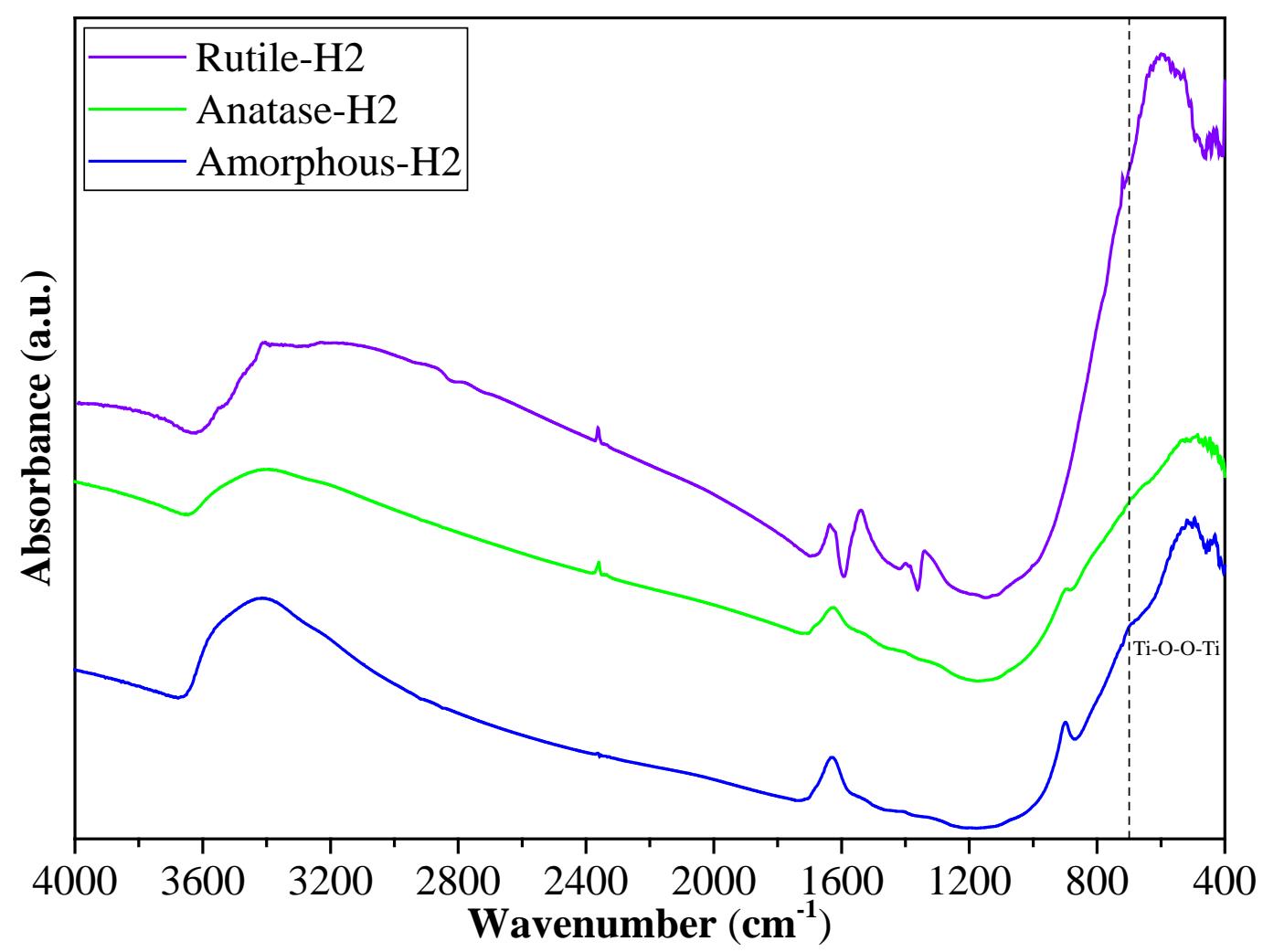

Figure 17 FT-IR spectra of the home-made Amorphous-H2, Anatase-H2 and Rutile-H2 $\mathrm{TiO}_{2}-\mathrm{s}$.

Consequently, the Raman spectra of the samples were recorded taking into account the following issues:

- sample Anatase-H2 contained mostly anatase and low amounts of rutile and brookite as well;

- sample Amorphous-H2 was amorphous, no specific signs of any crystal phases were present;

- both above-mentioned samples showed unique optical properties.

The reference sample in this case was AA, which is a pure anatase phase $\mathrm{TiO}_{2}$. As it can be seen in Fig. 18, sample AA showed the characteristic bands of anatase at (140, 394, 514 and $636 \mathrm{~cm}^{-1}$ ) [208]. These bands were also present in sample Anatase-H2, which is supported by the information obtained from XRD. However, the amorphous Amorphous-H2 sample showed weak bands of amorphous titania, most probably underway to be crystallized as anatase (bands at 514 and $636 \mathrm{~cm}^{-1}$ ). Even considering this, there were bands, which did not have any correspondence with any titania phase, such as the one located at $367 \mathrm{~cm}^{-1}$, a weak band at $420 \mathrm{~cm}^{-1}$ and an intense one at $900 \mathrm{~cm}^{-1}$. These unidentified bands seem to be related with the unknown band detected in the DR spectrum. 


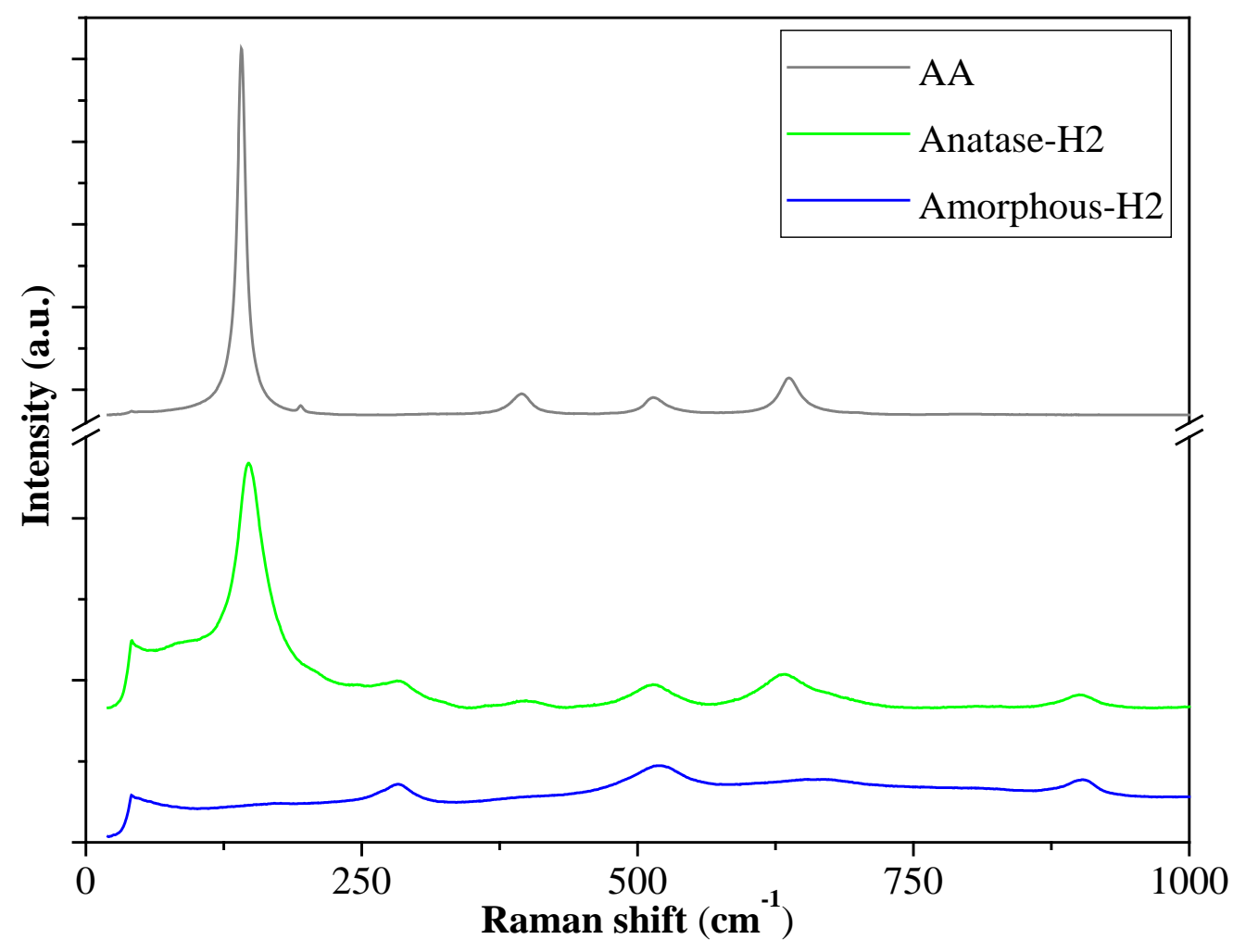

Figure 18 Raman spectra of home-made Amorphous-H2, Anatase-H2 and reference AA titania.

As described in Section 4.2, both Amorphous-H2 and Anatase-H2 samples were obtained using $\mathrm{NaOH}$. This synthesis method showed similarities with the synthesis of peroxotitanates used for ionic exchange application [209, 210]. Furthermore, in these two works, the unidentified bands were attributed to different sodium titanates $\left(\mathrm{Na}_{x} \mathrm{H}_{2}-\mathrm{x} \mathrm{Ti}_{3} \mathrm{O}_{7}\right)$. This new phase may be responsible for the unidentified DRS peak as well, located at 325 $\mathrm{nm}$. This means that the sign of sodium must be detectable. To reinforce this statement, and for the further characterization of the samples, XPS measurements were carried out (Fig. 19). 

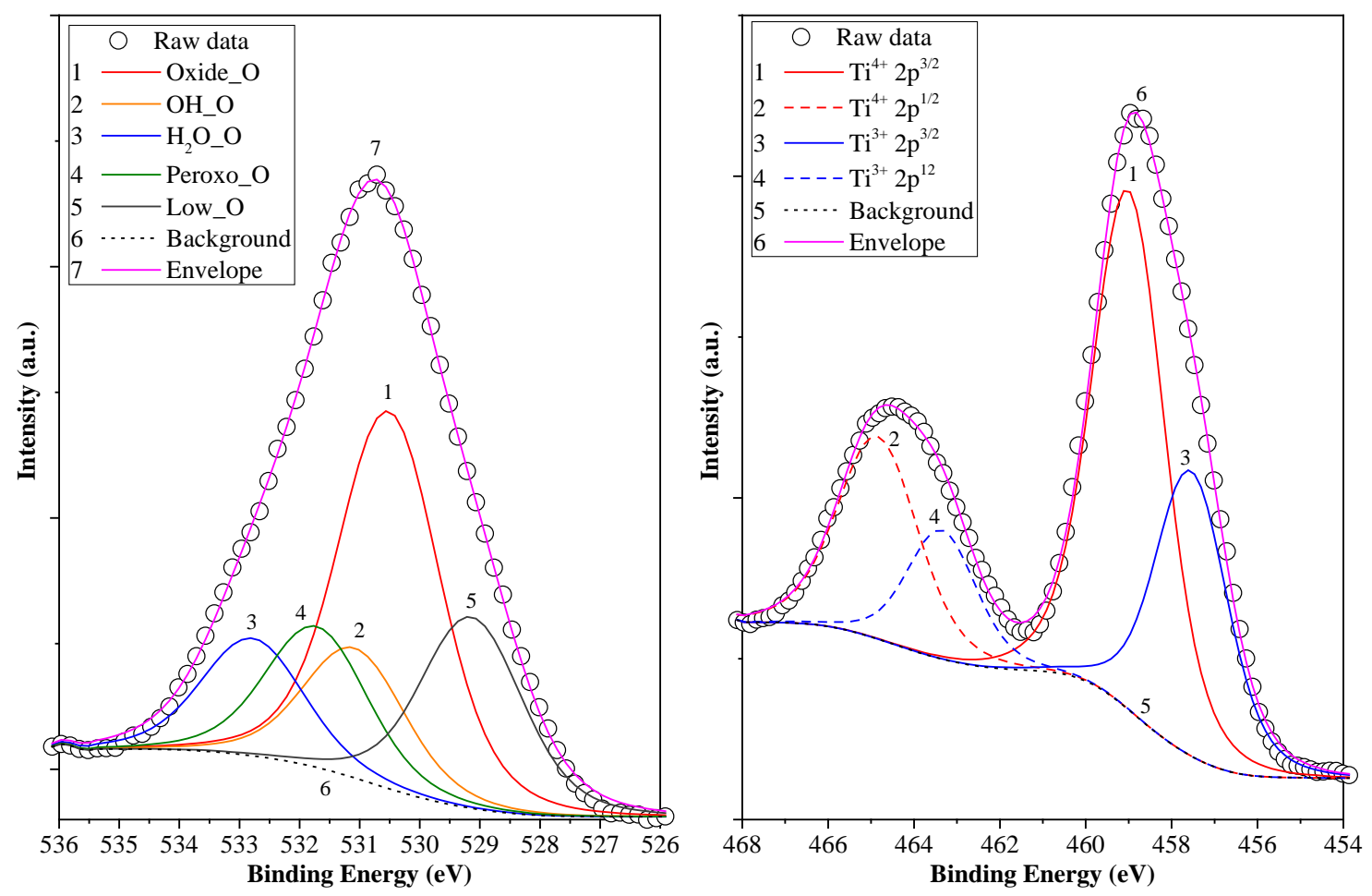

Figure 19 High-resolution O1s and Ti2p XPS spectra of Amorphous-H2.

In the first instance, the elemental composition was examined, and it was found that along the expected elements ( $\mathrm{Ti}$ and $\mathrm{O}$ ), sodium (Na1s binding energy at $1072 \mathrm{eV}$ ) was detected as well, bringing further evidence to the presence of sodium titanates. Furthermore, it should be noted that the values given below are valid for the surface of the materials and they are not total mass reported concentrations. In the Ti2p spectrum of the samples Amorphous-H2 and Anatase-H2 apart from $\mathrm{Ti}^{4+}, \mathrm{Ti}^{3+}$ was also detected in both samples, which may be responsible for the enhanced visible light absorption properties [198]. In terms of photoactivity the results are controversial in the literature, therefore this issue will not be considered. The amount of $\mathrm{Ti}^{3+}$ in Amorphous-H2 was 35.6\% from the total amount of $\mathrm{Ti}$ ( $0.65 \%$ from the total mass), while in the case of Anatase-H2 this value was $25.5 \%(0.41 \%$ from the total mass). This relatively high amount suggests the presence of low binding energy oxygen (peak location at $529.15 \mathrm{eV}$ ), which was successfully detected in both samples (20.0\% for Amorphous-H2 and 17.0\% for Anatase-H2). Moreover, surface anchored OH group oxygen (531.10 eV) [194], lattice oxygen (530.5 eV) [194], adsorbed water oxygen (532.71 eV) [195] were identified as expected, and more importantly, oxygen from peroxo groups in both samples at $531.80 \mathrm{eV}$ was also found [197]. This was anticipated based on the applied synthesis procedure and the band detected in the IR spectrum. However, 
the peroxide type oxygen was detected by IR only in sample Amorphous-H2. This result is in good accordance with the XPS measurements, as in sample Amorphous-H2 14.7\%, while in sample Anatase- $\mathrm{H} 2$ only $8.0 \%$ was the ratio of this oxygen type. The fact that the abundance of peroxo group-related oxygen is higher in amorphous samples was also observed by Zou et al. [130]. Finally, the peak located at $529.15 \mathrm{eV}$ may be attributed to titanate oxygen as well [211] (a clear deconvolution could not be carried out as the two species are very close in terms of binding energy), a further evidence in favor of titanates.

As discussed previously the samples may contain titanates, thus, to reinforce their presence the following points were taken into consideration:

- The presence of $\mathrm{Na}$ - detected as Na1s in XPS,

- Titanate $\mathrm{O}$ - detected in O1s XPS,

- Electron transition band at $325 \mathrm{~nm}$ in DR spectrum,

- Raman bands associated with different titanates.

If indeed there is titanate in the mentioned sample, it should be soluble in low concentration aqueous solution of weak organic acids, such as oxalic acid [212], therefore, the following experiment was carried out. Oxalic acid of $0.1 \mathrm{mM}, 0.5 \mathrm{mM}$ and $1 \mathrm{mM}$ containing the Amorphous- $\mathrm{H}_{2} \mathrm{TiO}_{2}$ in $1 \mathrm{~g} \cdot \mathrm{L}^{-1}$ concentration were prepared in which the sample partially dissolved, resulting in the color of the solution to change to yellow (the color of the photocatalyst). The degree and rate of partial dissolution increased as the acidity of the solution increased (by applying more concentrated oxalic acid).

\subsubsection{Photocatalytic activity}

Following the morpho-structural characterization, the photocatalytic activity of the samples was investigated using phenol; the decay curves are presented in Fig. 20. 


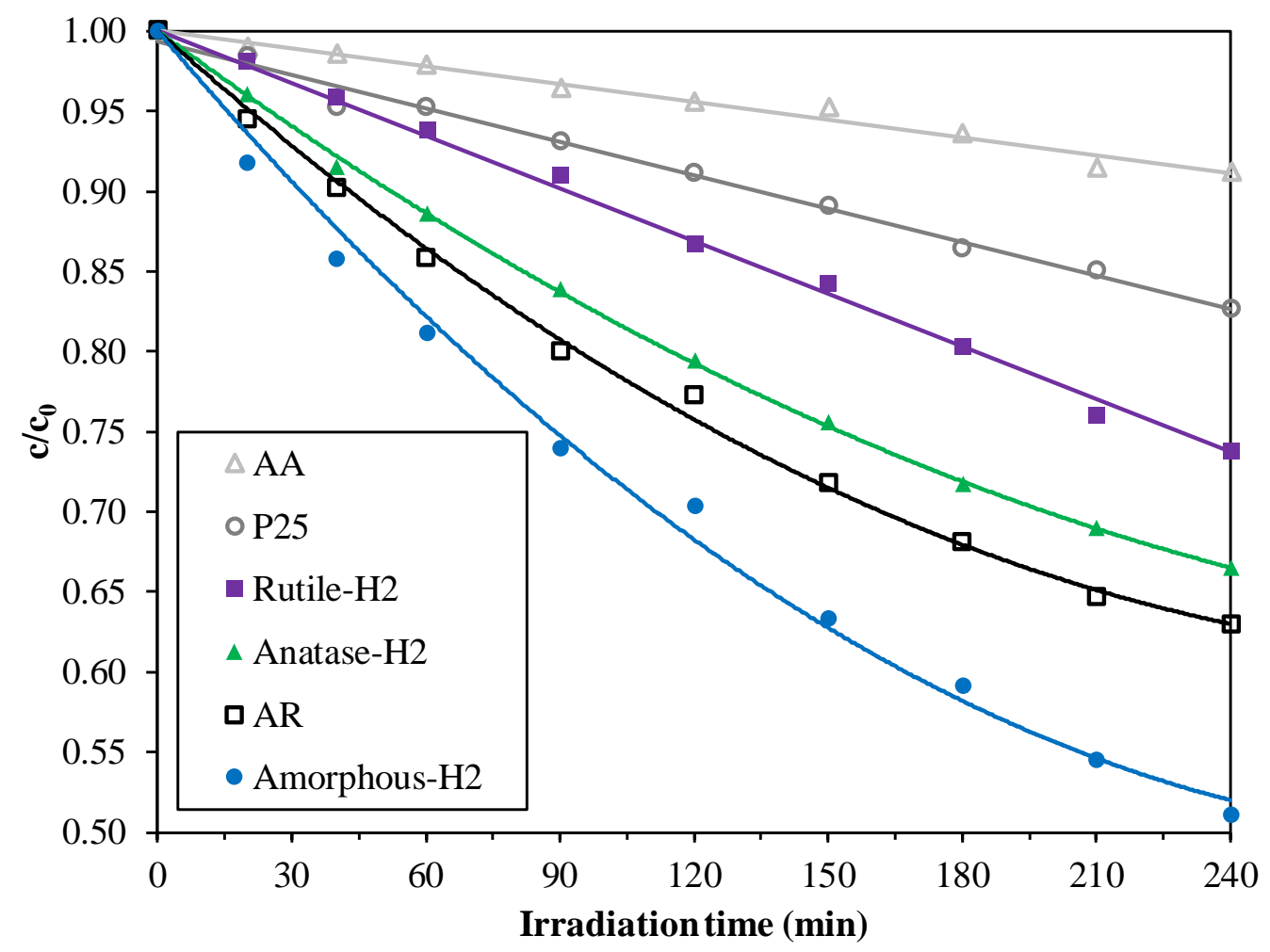

Figure 20 Decay curves of phenol under visible light irradiation.

Similarly to Section 5.1.2. visible light was applied for the excitation and the photocatalyst suspensions were left to be stirred in dark for $10 \mathrm{~min}$ to reach adsorption/desorption equilibrium and as expected, the changes in the concentration of phenol were negligible. Reference photocatalysts AA and P25 (which consist of entirely or predominantly anatase phase) had low, but notable photocatalytic efficiency, which can be explained by the formation of phenolic complexes on the surface of undoped titanium dioxides which can ultimately lead to the slight absorption of visible light via direct electron transfer between the surface complex and $\mathrm{TiO}_{2}$ conduction band [213-216], resulting a measurable photocatalytic efficiency in the case of pure anatase, as it was already observed in our previous publications $[68,69]$. Additionally, in the case of P25, its rutile content also contributed to the measured phenol degradation. All other investigated $\mathrm{TiO}_{2}$-s had higher efficiencies as it was expected, and our own peroxo-titania where the $\mathrm{pH}$ was modified during the synthesis had higher photocatalytic activity compared to the reference Rutile-H2, which was obtained without $\mathrm{pH}$ modification. Most importantly, it was found, that Amorphous- $\mathrm{H} 2 \mathrm{TiO}_{2}$ surpassed the photocatalytic efficiency of every investigated titania 
(49\% of the phenol was degraded), our own and reference photocatalysts alike, including the most efficient visible light active commercial Aldrich rutile.

As expected, initial phenol degradation rates (rovalues in Table 3) followed the same order (AA $<$ P25 $<$ Rutile-H2 $<$ Anatase-H2 $<$ AR $<$ Amorphous-H2) as decay curves; however, surface normalized photocatalytic efficiencies (Table 3) differed significantly. Aldrich rutile had by far the highest value, which suggests, that peroxo group-containing titania with higher particle size leads to outstanding surface normalized photocatalytic activity. In association with this statement it should be noted that in our previous work [182] it was also proved that the catalysts with higher particle size possessed higher surface normalized photocatalytic efficiency. Additionally, it should be highlighted, that the absolute photocatalytic activity of Amorphous-H2 was 1.65 times higher than Anatase-H2 photocatalyst's activity despite its 1.47 times lower specific surface area. Therefore, the surface normalized photocatalytic efficiency of Amorphous-H2 was more significantly (2.41 times) higher than the AnataseH2 catalyst's (in comparison with the absolute activities). However, it should be mentioned that the absolute activity is more important from the practical point of view.

Additionally, with the applied HPLC method, two main oxidation byproducts of phenol (pyrocatechol and hydroquinone) were detected, and no significant trends were observed in their concentration evolution during the degradation process.

\subsubsection{Further characterization and establishing connection between the results of morpho-structural characterization and photocatalytic activity}

The high visible light activity of Amorphous- $\mathrm{H} 2 \mathrm{TiO}_{2}$ raised important questions concerning the source of the catalytic property. The first step of the activation is the absorption of visible light photons. This criterion was satisfied for Rutile-H2, Amorphous$\mathrm{H} 2$ and for Anatase-H2 samples, which were active in visible light. The source of visible light absorption (recorded by DRS) was the presence of $\mathrm{Ti}^{3+}$ centers (proved directly by XPS), and peroxo groups (demonstrated by IR and XPS). The latter one was discussed indetail in our previous publication [182] and Section 5.1.3.

The main difficulty in identifying the key property is that sample Amorphous-H2 is amorphous according to XRD, while Anatase-H2 is a mixture of crystalline anatase, rutile and brookite, while Rutile-H2 is pure rutile. In the case of the latter one, the source of the visible light activity was the presence of the rutile phase (the band gap of rutile is $3.02 \mathrm{eV}$ ) and the successful anchoring of peroxo groups. Anatase-H2 contains predominantly anatase 
phase and the quantity of peroxo groups is higher than in Rutile-H2, while the brookite phase could also contribute to the visible light activity [53]. In the case of Amorphous-H2, the amount of the peroxo groups is very high (it was detectable even by IR spectroscopy), and DRS measurements showed similar visible light absorption properties compared to Anatase$\mathrm{H} 2$ with an additional electron transition band, observed in the first derivative of the DR spectrum. Examining more thoroughly the literature concerning amorphous semiconductors and their applicability it was found, that the semiconductive properties and band-structure of the materials are rather dependent on the interatomic bond length, instead of periodicity and ordered structures [217]. By considering this issue, it was demonstrated successfully that the band gap of amorphous materials should be higher compared to the crystalline materials, but concomitantly, this favors the appearance of localized states below the conduction band and above the valence band (similarly as in case of doping). These localized pseudo interband-gap states may be directly resulted from the presence of titanates/peroxo-titanates deduced by different means in the previous section (greater variability of Ti-O bond length - manifested in different oxygen species detected by XPS) and $\mathrm{Ti}^{3+}$. This would explain the double electron transition bands observed during the DRS measurements, one attributed to the band gap of the material $(\sim 3.4 \mathrm{eV})$ and the other one the inter-localized state transitions (visible light absorption band). Therefore, the steps explaining the photocatalytic activity of the highly active Amorphous-H2 sample may be the following:

- Absorption of the visible light photons.

- Charge carrier generation.

- Fast separation of the charges in the localized states.

- Degradation of model contaminant.

The mechanism proposed above may be valid not just in this case but in other cases as well, where poorly crystalline materials exhibit photocatalytic properties.

The stability of Amorphous-H2 and Anatase-H2 was also investigated after which the $\mathrm{TiO}_{2}$ samples were recollected, and XPS measurements were performed, similarly to samples Rutile-H2 and AR. In Section 5.1.2. Rutile-H2 $\mathrm{TiO}_{2}$ retained its photocatalytic activity (only 5.7\% reduction was observed after 3 reuses); however, after the second re-use cycle the observed degradation rate was lower than $5 \%$ of the original activity in the case of Amorphous-H2 $\mathrm{TiO}_{2}$ and $27.5 \%$ in the case of Anatase-H2 titania. For the explanation of this a plausible correlation between the obtained activity decrease and morpho-structural properties was sought together with establishing a trend within the samples. 
XPS measurements were carried out for the samples which were collected after the reutilization experiments. Before the measurements the powder was washed and dried (to remove any adsorbed organic material, which may influence the O1s XPS spectrum). It was found that the peroxo group ratio diminished in the case of sample Amorphous-H2 from 14.7 at $\%$ to 1.3 at\%, and in the case of Anatase-H2 from 8 at\% to 3.02 at\% (from the total amount of surface oxygen atoms), which correlates well with the findings of Shankar et al. where the decomposition of peroxo species after the experiments was confirmed by FT-IR and UVVis spectroscopy [129]. Concurrently, the OH_O O1s signal (surface OH group related oxygen) increased by $12.1 \%$ and $2.09 \%$, while the Oxide_O O1s signal (lattice oxygen) increased by $1.3 \%$ and $3.89 \%$ for Amorphous-H2 and Anatase-H2, respectively. These changes in the O1s spectra were attributed to the transformation of the peroxo groups into the as-described oxygen species. In the Ti2p spectra a decrease of $\mathrm{Ti}^{3+}$ was observed from $35.6 \%$ to $26.5 \%$ (from the total amount of surface titanium atoms) in the case of Amorphouse-H2 and $25.5 \%$ to $16.4 \%$ in the case of Anatase-H2, which resulted in a $9.1 \%$ increase in the ratio of the $\mathrm{Ti}^{4+}$ species in both cases. The changes were ascribed to the poor resistance of $\mathrm{Ti}^{3+}$ species against oxidation. From the observed results it was established that by illuminating the surface of the catalyst the following reactions probably occurred:

- $T$ The $\mathrm{Ti}^{3+}$ centers which were located near to a surface peroxo group, transformed from $\mathrm{Ti}^{3+}$ to $\mathrm{Ti}^{4+}$ as follows: $\mathrm{Ti}^{3+} \rightarrow \mathrm{Ti}^{4+}+\mathrm{e}^{-}$

- The above-mentioned electron can be captured by a photogenerated hole, or can act as a reductive agent as follows: $\mathrm{Ti}-\mathrm{O}-\mathrm{O}-\mathrm{Ti}_{(\text {(peroxo) }}+2 \mathrm{e}^{-}+2 \mathrm{H}^{+} \rightarrow 2 \mathrm{Ti}-\mathrm{OH}^{*}$

(* the proton originates from the slightly acidic phenol solution, while the resulting entities are surface anchored hydroxyl groups).

This redox couple may be the main cause of the activity deterioration. If this should be the case, then it must be valid for the other samples as well, a fact which may take the explanation to the second aspect mentioned above.

Finally, the as-obtained results - with the addition of $\mathrm{AR} \mathrm{TiO}_{2}$ as reference - were compared in terms of the crystallinity, peroxo group amount and photocatalytic activity of the samples. The main correlation found concerning the different samples were the following: as the crystallinity increased (evaluated by comparing the diffraction peak areas of self-made samples to commercial titania diffraction peak areas consisting of $100 \%$ crystalline phase; $<1 \%, 25 \%, 72 \%$ and $100 \%$ crystalline phase was calculated for Amorphous-H2, Anatase-H2, Rutile-H2 and AR respectively), the stability of the peroxo 
group increased as well and the activity decrease was less or none at all (>95\%, 72.5\%, 5.7\% and $<5 \%$ activity decrease for Amorphous-H2, Anatase-H2, Rutile- $\mathrm{H} 2$ and AR, respectively;

Table 4).

\begin{tabular}{|c|c|c|c|c|c|}
\hline \multirow{2}{*}{$\begin{array}{c}\text { Titanium } \\
\text { dioxide }\end{array}$} & Crystallinity (\%) & Peroxo group amount (at\%) & $\begin{array}{c}\text { Remaining } \\
\text { peroxo groups } \\
\text { (\%) }\end{array}$ & $\begin{array}{c}\text { Activity } \\
\text { decrease (\%) }\end{array}$ \\
\hline Amorphous-H2 & $<1$ & 14.7 & 1.3 & 8.8 & $>95$ \\
\hline Anatase-H2 & 25 & 8 & 3.02 & 37.8 & 72.5 \\
\hline Rutile-H2 & 72 & 5.24 & 2.83 & 54.5 & 5.7 \\
\hline AR & 100 & 8.9 & 5.29 & 59.4 & $<5$ \\
\hline
\end{tabular}

Table 4 Comparison of samples Amorphous-, Anatase-, Rutile-H2 and AR in terms of crystallinity, photocatalytic activity and peroxo group amount (from the total oxygen content) considering the phenol degradation experiments.

This finding is in good accordance with the fact, that highly active titania systems are known to contain sometimes oxygen vacancies $/ \mathrm{Ti}^{3+}$ centers in highly crystalline structures [194, 196]. Nevertheless, it can be found in the literature the so-called black titania, which contains a relatively high amount of $\mathrm{Ti}^{3+}$ which is also crystalline and stable, suggesting that this specie is stable when it is in a crystalline structure or embedded in one [218]. If amorphous and crystalline structures are compared it is evident, that in the amorphous one the abovementioned redox reaction couple is facilitated, while in crystalline structures it is inhibited due to the neighboring stabilization effects (fact demonstrated by the detection of $\mathrm{Ti}^{3+}$ after calcination in air) $[194,196]$. Therefore, the following correlation was deduced, that a certain degree of crystallinity is needed to preserve the activity enhancement conferred by the peroxo groups, but other aspects may also contribute to the stability, which were not investigated.

\subsection{Morphological modification [73, 99]}

Following the oxygen rich modification of anatase, rutile and even amorphous phase $\mathrm{TiO}_{2}$-s the most efficient rutile phase $\mathrm{TiO}_{2}$ (Rutile-H2) was selected for the further enhancement of its photocatalytic activity, since this sample proved to be the best, taking into account the stability and photocatalytic activity as well. Accordingly, as the next techniques for the enhancement of the photocatalytic activity the fabrication of composites and morphological modification - namely the development of hollow spherical structure - 
was investigated based on the following points. Carbon materials have the potential of improving the photocatalytic activity of $\mathrm{TiO}_{2}$ by (i) narrowing the band gap of the semiconductor; (ii) decreasing the recombination rate of photogenerated charge carriers; (iii) providing more active reaction/adsorption centers in greater amounts and higher surface area; (iv) acting as a photosensitizer for the photocatalytic reactions; (v) prolonging the lifespan of charge carriers [36, 179, 219]. There are numerous examples described in the literature where most of these advantageous effects were observed even when amorphous (i.e. not crystalline) carbon was used [220-222]. Conversely, the hollow spherical morphology can enhance the photocatalytic activity via enhancing the light trapping properties of the photocatalyst [21, 73, 99, 146, 155, 160, 161].

Since in our case the fabrication of hollow spherical $\mathrm{TiO}_{2}-\mathrm{s}$ is preceded by the construction of $\mathrm{TiO}_{2}-\mathrm{CS}$ composites, in this chapter it was investigated, whether the composite or the hollow spherical $\mathrm{TiO}_{2}$ by itself result in better photocatalytic activity.

\subsubsection{Characterization}

\subsubsection{Characterization of carbon sphere templates}

Following the synthesis of CS templates, firstly, the effect of the duration of hydrothermal treatment was studied on the yield and the size distribution. The relationship between the yield (determined from $\mathrm{m}_{\mathrm{cs}} / \mathrm{m}_{\text {sucrose}}$ ) and synthesis time is shown in Fig. 21.

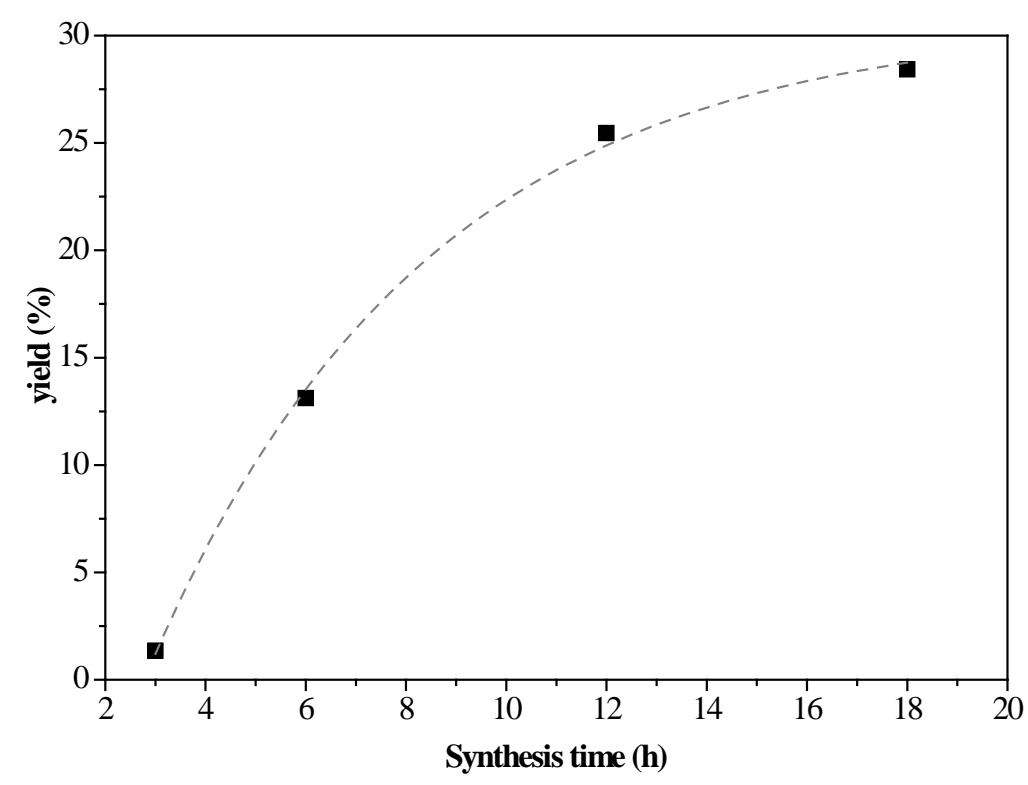

Figure 21 The effect of hydrothermal treatment duration on the yield of the carbon spheres. 
After the first (three-hour long) synthesis the yield was very low (1.4\%), which can be explained by the low nucleation rate of the CS seeds. By increasing the reaction time, the yield also increased, although after twelve hours the growth rate of yield decreased, and the process was most probably underway to saturation due to the consumption of the sucrose. Based on these findings, sufficient yields can be achieved by applying 12-hour reaction time. The size and morphology of the CSs were investigated by SEM measurements (Fig. 22).
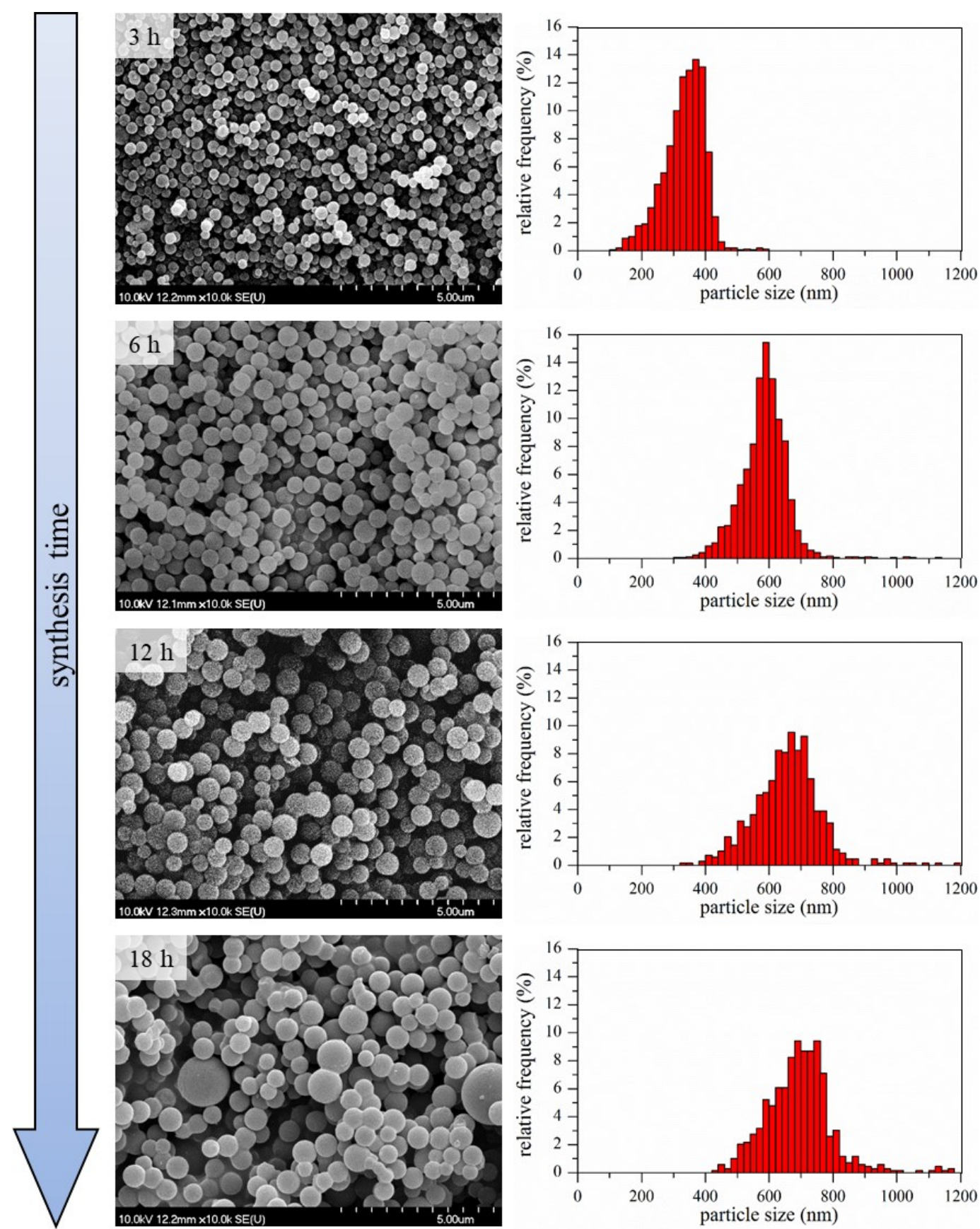

Figure 22 Morphology of carbon spheres prepared at different synthesis times (indicated in the upper left corner of the SEM pictures). Particle size distributions of CSs are shown in the histograms right to the corresponding SEM micrographs. 
Already after the first three-hour long synthesis (CS-3-7), well-defined sphere structures were observed. The diameter of the spheres was around $350 \mathrm{~nm}$ with a rather narrow size distribution. Six hours of hydrothermal treatment resulted similar product (CS-6-7) compared to the sample CS-3-7. The size distribution shifted towards bigger particle sizes; the average particle size was around $590 \mathrm{~nm}$. Wider size distribution was observed in the case of the CS-12-7 sample compared to CS-6-7, and the average size of the spheres also increased to $\sim 660 \mathrm{~nm}$. In this sample accreted spheres were also observed in a relatively low amount. This trend (increasing size and size distribution, appearance of accreted spheres, shift towards bigger particle sizes) continued in the case of sample CS-18-7 ( $\mathrm{d} \sim 700 \mathrm{~nm}$ ). Overall, at shorter synthesis times the nucleation of CSs was more significant, and later on the nucleation slowed down and the growth of CS became the dominant process. Based on these results, further experiments were carried out applying 12 hours of synthesis time.

As the next step, the effect of $\mathrm{pH}$ was investigated on the morphology of the CSs (Fig. 23).
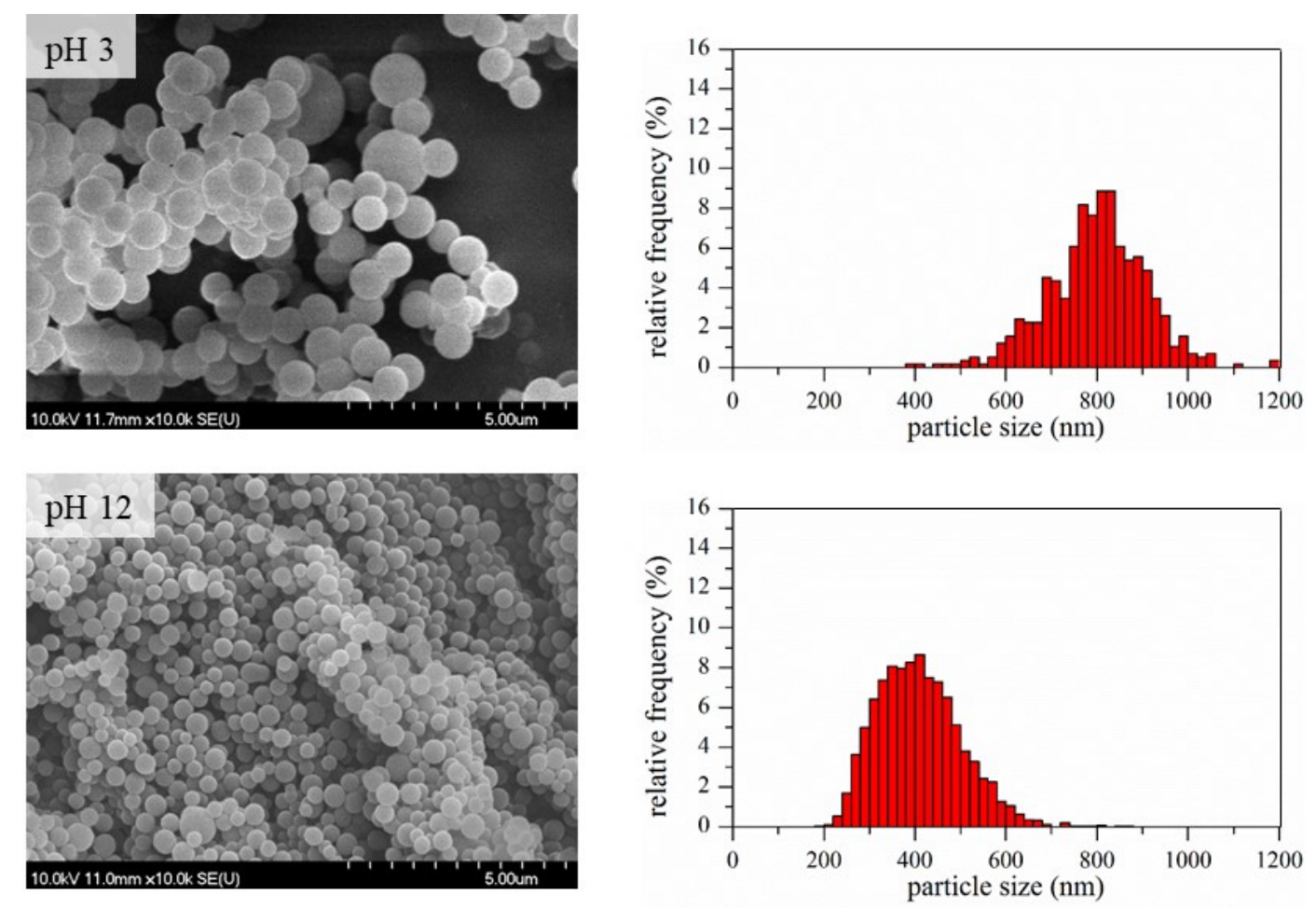

Figure 23 The effect of $\mathrm{pH}$ on the morphology of the prepared carbon spheres.

The $\mathrm{pH}$ values of the sucrose solutions were set to 3 and 12 before the hydrothermal treatment (the sample of $\mathrm{pH}$ 7, CS-12-7, has already been described in the previous section). 
With increasing $\mathrm{pH}$, only a slight increase was observed concerning the yields: 23\%, 26\% and 28\% yields were calculated for the CS-12-3, CS-12-7 and CS-12-12 samples, respectively. The effect of $\mathrm{pH}$ can be clearly seen in the case of sample CS-12-3 (synthesized under acidic conditions) and CS-12-12 (synthesized under basic conditions). CS-12-3 had an average particle size of $810 \mathrm{~nm}$ with rather wide particle size distribution and contained accreted particles. In the case of sample CS-12-7 similar particle size distribution was observed compared to CS-12-3; however, the average particle size decreased to around $660 \mathrm{~nm}$. CS-12-12 showed narrower size distribution compared to the previous samples. The average particle size was around $400 \mathrm{~nm}$ and the presence of accreted particles was not prominent. According to these results it was established that the $\mathrm{pH}$ of the sucrose solution has significant impact on the size of the prepared CSs, for which a plausible explanation can be the following: Firstly, sucrose undergoes dehydration resulting HMF (5(hydroxymethyl)-2-furaldehyde) which then take part in polymerization and aldol condensation reactions [158, 159, 223]. It is reported that aldol reaction of cyclic and aromatic ketones/aldehydes are more favorable under alkaline conditions [224]. Thus, this may lead to faster accumulation of polymerized species which eventually results rapid nucleation. Subsequently, particle growth is more decisive in the later period of the hydrothermal process resulting increased number of smaller particles. In acidic media, the nucleation is somewhat elongated, followed by particle growth resulting larger particles and wide particle size distribution. Since sample CS-12-12 could be synthesized with reasonably good yield and the CSs were quite uniform, thus it has been selected to be used studied further and used as template for the preparation of $\mathrm{TiO}_{2}$ hollow structures.

CS-12-12 sample was studied with various techniques. XRD was used to investigate the possible crystallinity of the CSs (Fig. 24a). 

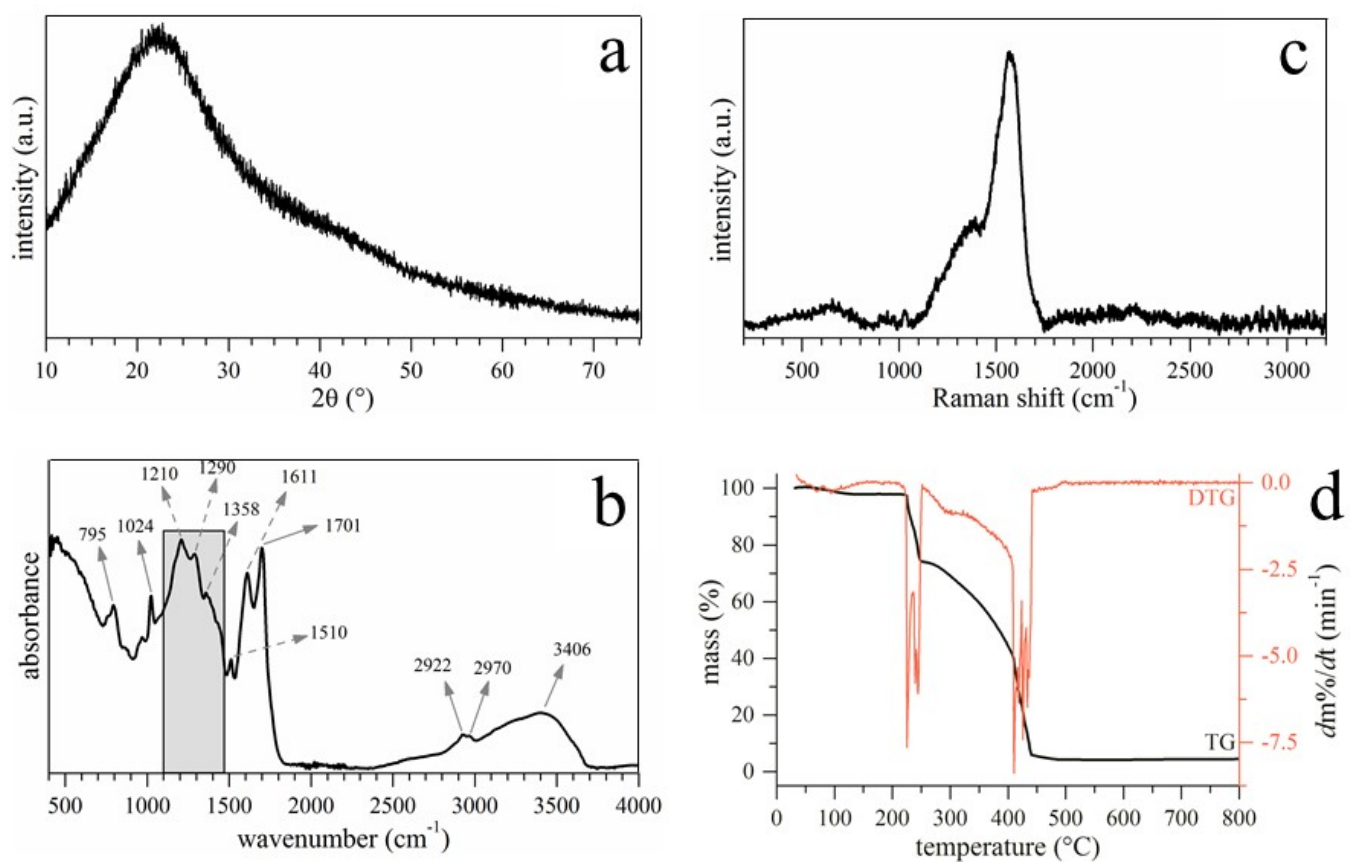

Figure 24 X-ray diffraction pattern (a), Raman (b), FT-IR spectra (c) and TG curve (d) of CS-12-12.

Only one broad peak was observed around $22^{\circ}\left(2 \theta^{\circ}\right)$, which was attributed to amorphous carbon [225]. Reflection at $\sim 26.5^{\circ}$ was not detected which would indicate well-structured graphitic segments, and no other crystalline impurities were detected. Then, Raman spectroscopy was used to analyze the CSs (Fig. 24b). In the Raman spectra the typical Raman features of carbon materials were observed: the D ( 1350 cm$\left.{ }^{-1}\right)$ and G $\left(\sim 1580 \mathrm{~cm}^{-1}\right)$ bands. The $\mathrm{D}$ band can be attributed to the presence of $\mathrm{sp}^{3}$ hybridized carbon atoms and the $\mathrm{G}$ band is an indicator of conjugated $\mathrm{sp}^{2}$ carbon atoms. Both $\mathrm{D}$ and $\mathrm{G}$ bands are broad, indicating a rather amorphous structure. The high intensity $\mathrm{G}$ band compared to the $\mathrm{D}$ band implies that most of the material consists of conjugated carbon framework. FT-IR measurements were applied to investigate the surface properties of the CSs (Fig. 24c). The broad band between 1800 and $3800 \mathrm{~cm}^{-1}$ was attributed to physisorbed water and the stretching vibrations of structural OH groups. Peaks at 2970 and $2922 \mathrm{~cm}^{-1}$ can be assigned to $\mathrm{C}-\mathrm{H}$ stretching vibrations, and bands at 1701 and $1611 \mathrm{~cm}^{-1}$ indicate $\mathrm{C}=\mathrm{O}$ stretching vibration and $\mathrm{C}=\mathrm{C}$ vibration (most probably in the aromatic ring), respectively. In the case of the band at $1611 \mathrm{~cm}^{-1}$, some oxygen containing groups (e.g. cyclic ethers) could appear in the same region as well. The signals in the spectral range of $1100-1400 \mathrm{~cm}^{-1}$ correspond to $\mathrm{C}-\mathrm{OH}$ stretching vibration and $\mathrm{OH}$ bending vibration, indicating the presence of hydroxyl groups in large quantities [226-230]. The thermal behavior of CSs was also investigated 
(Fig. 24d). Two intense weight losses were observed during the heating of CSs in oxygen atmosphere. The first interval was $220-250{ }^{\circ} \mathrm{C}$ and the second $410-440{ }^{\circ} \mathrm{C}$, and in between the two another region was detected where a moderate mass loss took place. The former is most probably due to the decomposition of various oxygen containing functional groups while the latter is due to the combustion of the carbon itself [231, 232]. After these measurements the synthesis and characterization of the CSs were repeated, but this time acetone was used to purify the CSs and the results were practically identical, thus for the preparation of $\mathrm{TiO}_{2}$ coating and subsequent measurements the CSs purified with the more economical acetone were applied (unless stated otherwise). To sum up the results, our CSs contained amorphous carbon with no graphitic domains; however, Raman and FT-IR results indicated the presence of conjugated/aromatic segments as well as various oxygen containing functional groups.

As the last parameter the effect of the applied purification method (used in order to eliminate the various contaminants formed during the hydrothermal synthesis) was investigated on the properties of the resulting CSs. According to X. Sun and Y. Li, during the hydrothermal synthesis of carbon spheres the following steps occur (in accordance with the LaMer model [233]): (i) after reaching the necessary concentration and temperature of the solution, aromatic compounds and oligosaccharides form (indicated by the increasing viscosity and the orange/red color of the solution), then polymerization occurs, (ii) the solution reaches supersaturation resulting in nucleation followed by the cross-linking of linear/branchlike oligosaccharides and other macromolecules, (iii) the as-formed nuclei grow uniformly and isotropically by the diffusion of solutes reaching its final size [229]. In the case of the previously discussed and characterized CSs, they were purified with vacuum filtration; however, it resulted in quite low flux (leading to unsatisfactory CS yield) due to the fouling of the filter. Consequently, membrane filtration (which enabled magnetic stirring to be applied during the filtration) was used in order to increase the yield, then similar morpho-structural characterization was carried out (compared to sample CS-12-12). This method also enabled the investigation of purification efficiency in terms of the quantities of solvent used during the purification. These CSs were denoted as CS_1, CS_2 and CS_3; purified by the application of 1, 3 and 5 acetone washing cycles and 1, 1 and 2 MQ washing cycles, respectively. As expected, the different purification method did not change the structure and morphology of the CSs (verified by XRD and SEM measurements); however, based on the FT-IR measurements surprisingly no differences were observed in the surface 
properties either (Appendix 1), from which it can be presumed, that by the utilization of these CSs no considerable difference should be observable in the properties of the resulting HSs. Membrane filtration as a purification method did not prove to be feasible and economical enough either: until achieving $\mathrm{VRR}=5$ volume reduction ratio in every cycle, still high amount of residuals ( $20 \%$ of the initial amount of the given cycle) can remain in the solution (and higher VRR would be very hard to achieve, due to the observed significant flux reduction, despite the intensive stirring). Because of this as the last technique centrifugation was investigated which can result in several orders of magnitude higher purification efficiency of the CSs. Ultimately, this method proved to be the most appropriate for the purification of the CSs from the economic and feasibility point of view, and most importantly, yield-wise. The CSs purified this way had similar characteristic properties as before (like in the case of CSs purified with vacuum filtration or membrane filtration).

\subsubsection{Characterization of $\mathrm{TiO}_{2}-\mathrm{CS}$ composites and $\mathrm{TiO}_{2}$ hollow structures}

As the next step, $\mathrm{TiO}_{2}-\mathrm{CS}$ composite (denoted as 'H2_CS_0') was synthesized by coating the CS templates with the previously described 'Rutile-H2' titanium dioxide and was compared to the $\mathrm{TiO}_{2}$ hollow structure (denoted as 'H2_HS_0'), which was obtained by the calcination of the composite in muffle furnace. The as-prepared composite and hollow structure were characterized by XRD (Appendix 2a) and it was found, that both contained anatase phase $(72 \%, 62 \%$ and D $=9.7 \mathrm{~nm}, 14.2 \mathrm{~nm}$ for H2_CS_0 and H2_HS_0 respectively) to a larger extent, compared to rutile phase $(28 \%, 38 \%$ and $\mathrm{D}=16.4 \mathrm{~nm}, 17.9 \mathrm{~nm}$, for H2_CS_0 and H2_HS_0, respectively). The main difference in the diffraction patterns of the 2 samples was the level of crystallinity (the intensity of the diffractions of H2_HS_0 was much higher), which can be explained by the result of calcination (as well as the increase in crystallite sizes). This result is in good accordance with our previous observations, that applying amorphous carbon results in the coating being amorphous as well, and similarly, using crystalline carbon template results in crystalline coating, respectively [234]. Afterwards, these samples were characterized by IR measurements (Appendix 2b) and as expected, all the peaks observed earlier in the previous section in the case of CSs, also appeared in the case of the composite sample. Additionally, a less intense peak at $1029 \mathrm{~cm}^{-1}$ was detected, which can be attributed to residues of disaccharides [235, 236]. The broad absorption band between $400-600 \mathrm{~cm}^{-1}$ can be assigned to the transverse optical vibration of Ti-O bonds [206], proving the presence of $\mathrm{TiO}_{2}$ coating layer. Most importantly, these 
measurements were followed by the evaluation of photocatalytic activity (Appendix 2c), and it was found, that H2_CS_0 possessed less than half of the photocatalytic efficiency of the H2_HS_0 sample. Finally, SEM measurements were also carried out before (Appendix 2d) and after (Appendix 2e) the elimination of CSs and it was found, that the spherical morphology was damaged during the treatment and only a few spherical entities could be detected. To sum up, it was observed, that compared to Rutile-H2, the presence of carbon spheres significantly decreased the crystallinity and photocatalytic activity of the sample. Concurrently, compared to H2_CS_0 composite sample, after calcination the H2_HS_0 sample possessed higher crystallinity as expected, and consequently, higher photocatalytic activity. Based on that discovery (and that the composites always had lower photocatalytic activity then their hollow spherical counterpart in the case of the subsequent samples as well), the composite samples (and $\mathrm{H}_{2} \_\mathrm{HS} \_0 \mathrm{TiO}_{2}$ ) were not investigated and discussed further, and more emphasis was put on the characterization of hollow structures, since despite the increased photocatalytic activity of the hollow structural $\mathrm{TiO}_{2}$ (compared to the composite material), the photocatalytic activity of Rutil-H2 still has not been exceeded, presumably partly due to the imperfect morphology, thus we aimed to improve it by finetuning the synthesis parameters.

As the next step, we investigated if by the application of variously purified carbon spheres and different synthesis parameters the beneficial properties of the unique morphology can be utilized, thus surpassing the photocatalytic activity of the reference Rutile-H2 $\mathrm{TiO}_{2}$. The applied CSs, the name of the $\mathrm{TiO}_{2}$ samples and the various synthesis conditions were summarized in Table 5.

\begin{tabular}{|c|c|c|c|c|c|}
\hline CS purification method & $\begin{array}{c}\text { Washing } \\
\text { cycles }\end{array}$ & TiO $_{2}$ & $\begin{array}{c}\text { TiO }_{2} \text { :CS } \\
\text { weight ratio }\end{array}$ & Furnace & Quality of HSs \\
\hline Membrane filtration & 3 & H2_HS_1 & 0.84 & $\begin{array}{c}\text { Muffle (without air } \\
\text { supply) }\end{array}$ & $*$ \\
\hline Membrane filtration & 1 & H2_HS_2 & 0.26 & $\begin{array}{c}\text { Muffle (without air } \\
\text { supply) }\end{array}$ & $* *$ \\
\hline Membrane filtration & 3 & H2_HS_3 & 0.26 & $\begin{array}{c}\text { Muffle (without air } \\
\text { supply) }\end{array}$ & $* *$ \\
\hline Membrane filtration & 5 & H2_HS_4 & 0.26 & $\begin{array}{c}\text { Muffle (without air } \\
\text { supply) }\end{array}$ & $* *$ \\
\hline Centrifugation & - & H2_HS_5 & 0.26 & $\begin{array}{c}\text { Muffle (without air } \\
\text { supply) }\end{array}$ & $* * *$ \\
\hline Centrifugation & - & H2_HS_6 & 0.26 & $\begin{array}{c}\text { Tube (with constant } \\
\text { air supply) }\end{array}$ & $* * *$ \\
\hline
\end{tabular}

Table 5 Applied synthesis parameters during the preparation of $\mathrm{TiO}_{2}-\mathrm{CS}$ composites and HSs (*: no HSs; **: moderate quality HSs; ***: good quality HSs). 
For the first synthesis of composite and HS, membrane filtered CS was applied, and the applied quantity of the precursor was three times higher compared to the one written in the experimental section. After performing the coating and subsequent SEM measurement, it was found that the quantity of $\mathrm{TiO}_{2}$ precursor was too high, which resulted in the formation of irregular $\mathrm{TiO}_{2}$-CS composite (in terms of shape) and $\mathrm{TiO}_{2}$ nanoparticle aggregates (Appendix 3). Accordingly, after calcination (sample denoted as 'H2_HS_1') no regular HSs were observed therefore the quantity of the $\mathrm{TiO}_{2}$ precursor was reduced to one third (as the volumes are described in the experimental section), which resulted in successful coating of the CSs. By the utilization of CSs purified by membrane filtration with increasing amount of acetone/water (denoted as CS_1, CS_2 and CS_3) further $\mathrm{TiO}_{2}-\mathrm{HSs}$ were synthesized (denoted as 'H2_HS_2-4') which displayed the desired hollow structural morphology based on the SEM micrographs; however, the morphology was still imperfect, as a significant amount of damaged structures were also observed. The quality of HSs was mostly uniform, which is in good accordance with the IR results, since the features of the CSs' surface was generally identical. At this point, the crystallinity of the as-prepared $\mathrm{TiO}_{2}-\mathrm{HSs}$, and reference photocatalysts (Aeroxide P25, Rutile-H2 and Rutile-H2_calc) was determined by XRD measurements (Fig. 25a). The crystal phase distributions, average primer particle sizes were presented in Table 6.
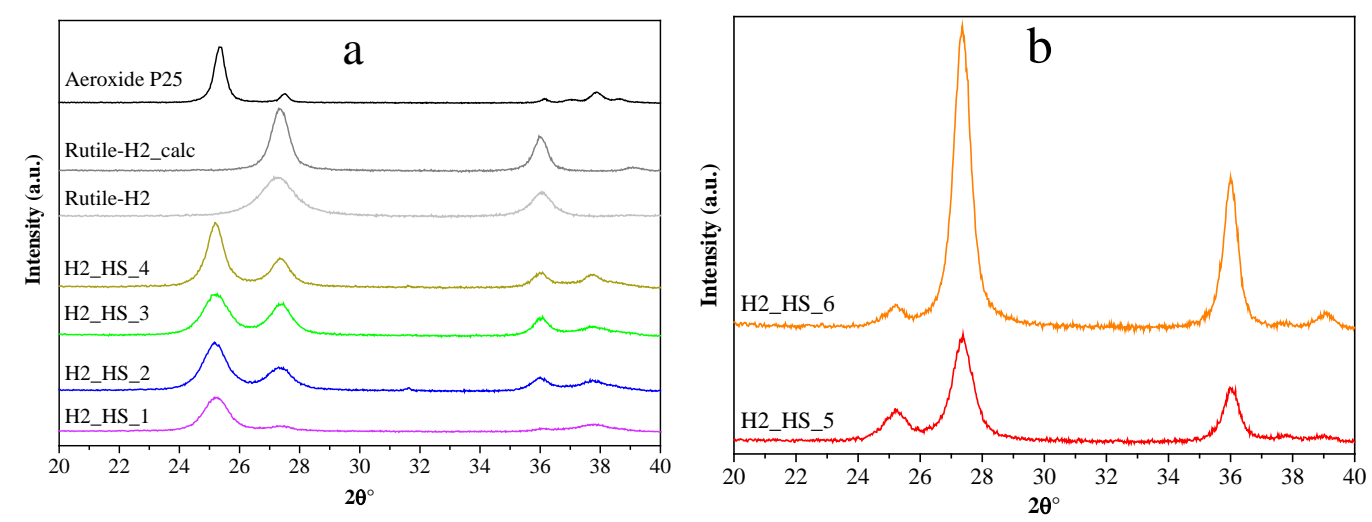

Figure $25 \mathrm{X}$-ray diffraction patterns of the home-made predominantly anatase phase $\mathrm{TiO}_{2}$ s and P25 (a), and our home-made rutile phase $\mathrm{TiO}_{2}-\mathrm{s}(\mathrm{b})$. 


\begin{tabular}{|c|c|c|c|c|c|}
\hline \multirow{3}{*}{$\begin{array}{l}\text { Titanium } \\
\text { dioxide }\end{array}$} & \multicolumn{5}{|c|}{ Phase composition } \\
\hline & \multicolumn{3}{|c|}{ Anatase } & \multicolumn{2}{|c|}{ Rutile } \\
\hline & \multicolumn{2}{|c|}{ wt $\%$} & $\begin{array}{l}\text { Particle size } \\
\text { (nm) }\end{array}$ & wt $\%$ & $\begin{array}{c}\text { Particle size } \\
\text { (nm) }\end{array}$ \\
\hline H2_HS_1 & \multicolumn{2}{|c|}{87.72} & 9.7 & 12.28 & 10.7 \\
\hline H2_HS_2 & \multicolumn{2}{|c|}{66.42} & 10.3 & 33.58 & 9.7 \\
\hline H2_HS_3 & \multicolumn{2}{|c|}{56.91} & 9.3 & 43.09 & 10.8 \\
\hline H2_HS_4 & \multicolumn{2}{|c|}{64.1} & 15 & 35.9 & 12.9 \\
\hline H2_HS_5 & \multicolumn{2}{|c|}{20} & 12.3 & 80 & 12.9 \\
\hline H2_HS_6 & \multicolumn{2}{|c|}{4.8} & 18 & 95.2 & 15.5 \\
\hline Rutile-H2 & \multicolumn{2}{|c|}{$<1$} & - & $>99$ & 7.3 \\
\hline Rutile-H2_calc & \multicolumn{2}{|c|}{$<1$} & - & $>99$ & 14.1 \\
\hline Aeroxide P25 & \multicolumn{2}{|c|}{90} & 25.4 & 10 & 40 \\
\hline $\begin{array}{c}\text { Titanium } \\
\text { dioxide }\end{array}$ & $\begin{array}{c}\text { Diameter } \\
(\mathrm{nm})\end{array}$ & $\begin{array}{c}\text { Specific } \\
\text { surface area } \\
\left(\mathrm{m}^{2} \mathrm{~g}^{-1}\right) \\
\end{array}$ & Band gap $(\mathrm{eV})$ & $\begin{array}{c}r_{0, \text { phenol }} \\
\left(10^{-10} \mathrm{M} \mathrm{s}^{-1}\right)\end{array}$ & $\begin{array}{c}\mathbf{r}_{0, \text { phenol }} \\
\left(10^{-12} \mathrm{M} \mathrm{m}^{-2} \mathrm{~s}^{-1}\right) \\
\text { surface normalized }\end{array}$ \\
\hline H2_HS_1 & - & 89 & 3.14 & 8.1 & 9.1 \\
\hline H2_HS_2 & 1202 & 70 & 3.14 & 6.03 & 8.6 \\
\hline H2_HS_3 & 1137 & 65 & 3.15 & 5.26 & 8.1 \\
\hline H2_HS_4 & 1237 & 46 & 3.13 & 7.02 & 15.3 \\
\hline H2_HS_5 & 880 & 40 & 3.13 & 24.63 & 61.6 \\
\hline H2_HS_6 & 943 & 46 & 3.13 & 13.65 & 29.7 \\
\hline Rutile-H2 & - & 237 & 3.11 & 18.3 & 7.7 \\
\hline Rutile-H2_calc & - & 39 & 3.09 & 3.4 & 8.8 \\
\hline Aeroxide P25 & - & 49 & 3.11 & 12.3 & 25.1 \\
\hline
\end{tabular}

Table 6 Phase composition, average primary particle sizes, band gaps, and specific surface areas of the investigated $\mathrm{TiO}_{2}$-s.

Samples H2_HS_1-4 contained predominantly anatase (1 01 1) phase (main diffraction peak at $25.62 \theta^{\circ}$ ). The size of the primer crystallites, which were the building elements of the hollow structures varied between 9.3 and $15.0 \mathrm{~nm}$. Reference photocatalysts Rutile-H2 (D = $7.3 \mathrm{~nm}$ ) and Rutile-H2_calc (D = $14.1 \mathrm{~nm}$ ) contained only rutile (1 110$)$ (main diffraction peak at $27.22 \theta^{\circ}$ ). The size increase (and concurrent considerable loss of specific surface area) of Rutile-H2_calc can be explained by the result of calcination. 
To sum up the results so far, the synthesis parameters applied in the case of sample H2_HS_1 were not adequate, but after the reduction of precursor quantity (samples H2_HS_2-4) the coating process was successful (in the case of all the subsequent samples). However, the morphology was still imperfect (because of the considerable number of damaged spheres formed during the calcination) and our samples contained mainly anatase phase which is not excitable by visible light. Additionally, in the publication of Mahyar et al. they showed, that media with different polarity (a series of primer alcohols) can set up the formation of different crystal phases [237]. Based on this, it was assumed, that by applying different solvents for washing the surface of the CSs, differences in the quality of the surface can be induced, influencing the forming crystal phase composition of the deposited $\mathrm{TiO}_{2}$. Since our goal was to synthesize visible light-active $\mathrm{TiO}_{2}$-s, to which rutile phase is more advantageous (as it is excitable by visible light), further on only acetone was used as purifier solvent, and the more feasible centrifugation was applied as the purification method of CSs (resulting in sample H2_HS_5). Moreover, since after the reduction of precursor quantity the coating process was always successful, and the damaged structures were obtained only after calcination, another sample was synthesized where tube furnace with air supply was used for the elimination of carbon spheres (sample H2_HS_6) in contrast with using muffle furnace without additional air supply (samples H2_HS_1-5). Applying such synthesis parameters, samples H2_HS_5-6 both possessed good quality hollow structural morphology (Fig. 26), and predominantly rutile phase (Fig. 25b).

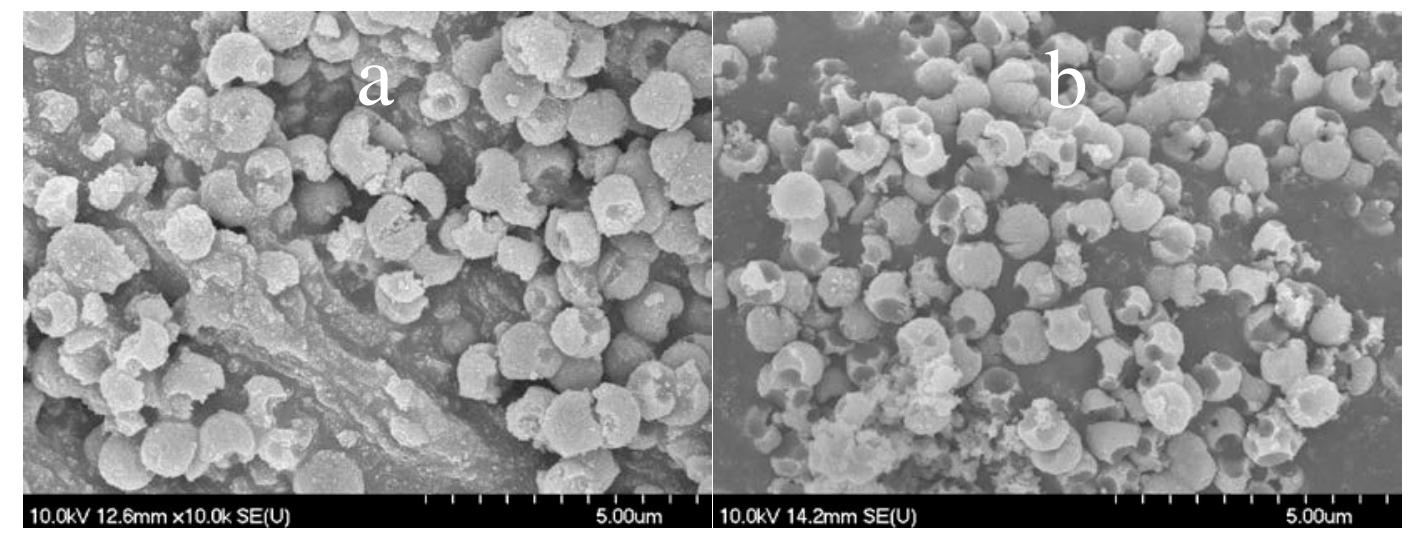

Figure 26 SEM micrographs of the H2_HS_5 (a) and H2_HS_6 (b) samples.

Based on their greater rutile content and more importantly, the regular morphology, it was expected that these $\mathrm{TiO}_{2}$-s (H2_HS_5-6) should have increased photocatalytic efficiency under visible light irradiation compared to the other $\mathrm{TiO}_{2}-\mathrm{S}$ in the series (H2_HS_1-4), as 
rutile absorbs visible light to a certain extent (having a band gap of $3.02 \mathrm{eV}$ [55]) whereas anatase does not, and the hollow structure may enable the better utilization of visible light, as this was already proved in the case of UV irradiation of $\mathrm{TiO}_{2}$ hollow structures $[21,155]$. To sum up, it was deduced, that the quality of HS morphology is largely dependent on the precursor quantity and the purification method of carbon spheres.

The light absorption of the $\mathrm{TiO}_{2}-\mathrm{s}$ was determined by diffuse reflectance spectroscopy (DRS). As it can be seen in Fig. 27 the $\mathrm{TiO}_{2}-\mathrm{HSs}$ possess greater light absorption in the visible light region compared to reference Rutile-H2 and Aeroxide P25. The band gap energies - determined from the derivative DR spectra - were 3.14, 3.14, 3.15, 3.13, 3.13, 3.13 eV for H2_HS_1-6 photocatalysts, and 3.11, 3.09, 3.11 eV for Rutile-H2, Rutile-H2_calc and Aeroxide P25, respectively.



Figure 27 DR spectra of the investigated $\mathrm{TiO}_{2}-\mathrm{s}$.

Based on the DRS results, samples H2_HS_1-6 possess very similar values, thus possible differences in their activity presumably will not be attributable to their band gaps. 


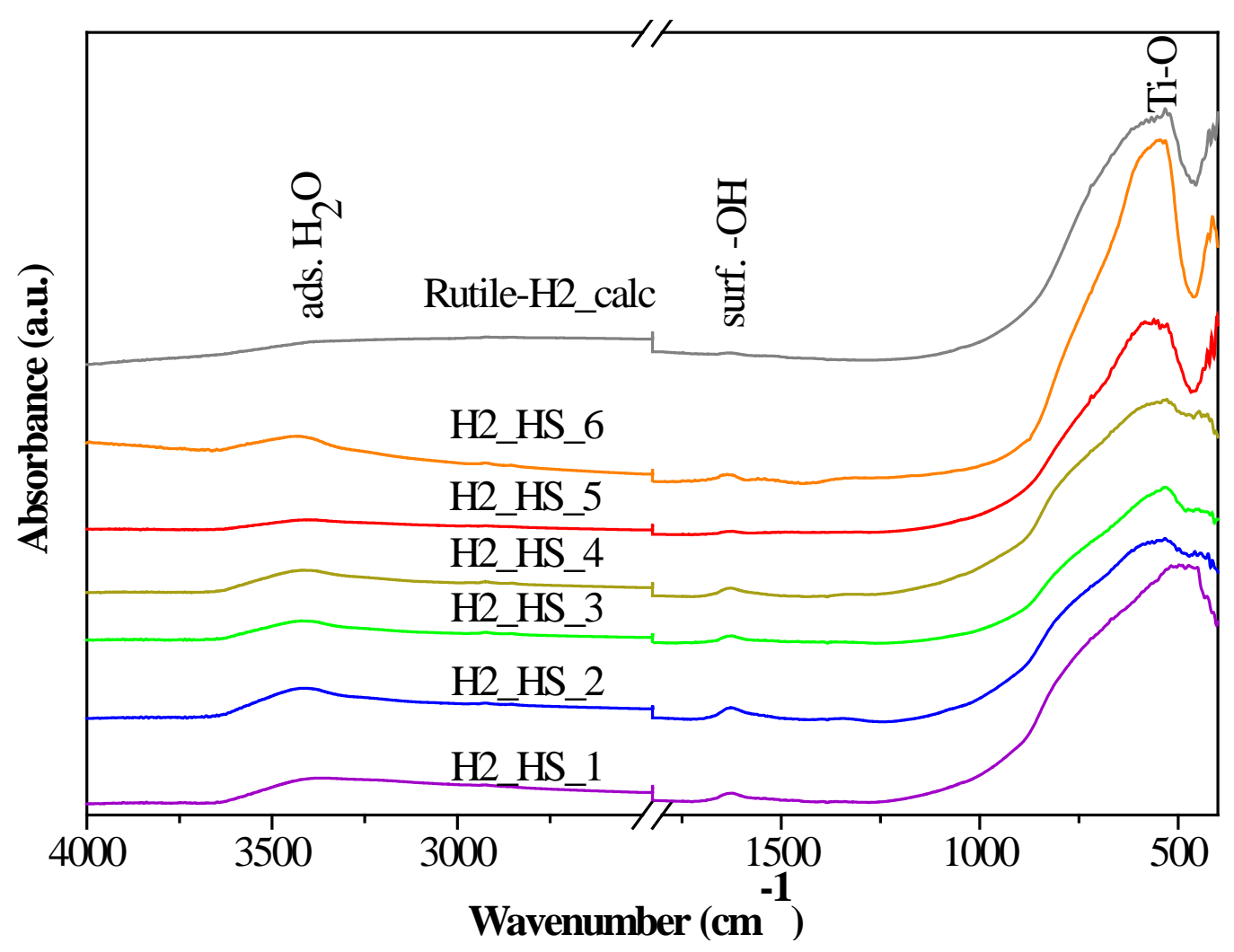

Figure 28 IR spectra of the investigated $\mathrm{TiO}_{2}-\mathrm{s}$.

Surface properties of $\mathrm{TiO}_{2}$-HSs were characterized by FT-IR spectroscopy (Fig. 28). In the FT-IR spectra a broad band centered at $3400 \mathrm{~cm}^{-1}$ with a sharp band at $1630 \mathrm{~cm}^{-1}$ were observed, which can be associated with the stretching and bending vibrations of the surface OH groups [187, 188], moreover, the bands around 480 and $540 \mathrm{~cm}^{-1}$ corresponds to Ti-O bond [206]. The shape of these latter bands in this region varied in accordance with the different crystal phases; anatase had less defined Ti-O stretch band as it possesses less ordered structure (compared to rutile), consequently, in the case of mixed crystal phases, the infrared absorption bands also represented this transmission between the two crystal phases [238].

\subsubsection{Photocatalytic activity}

Similar as before, after the morpho-structural characterization the photocatalytic was investigated using phenol and the results are presented in Fig. 29. 


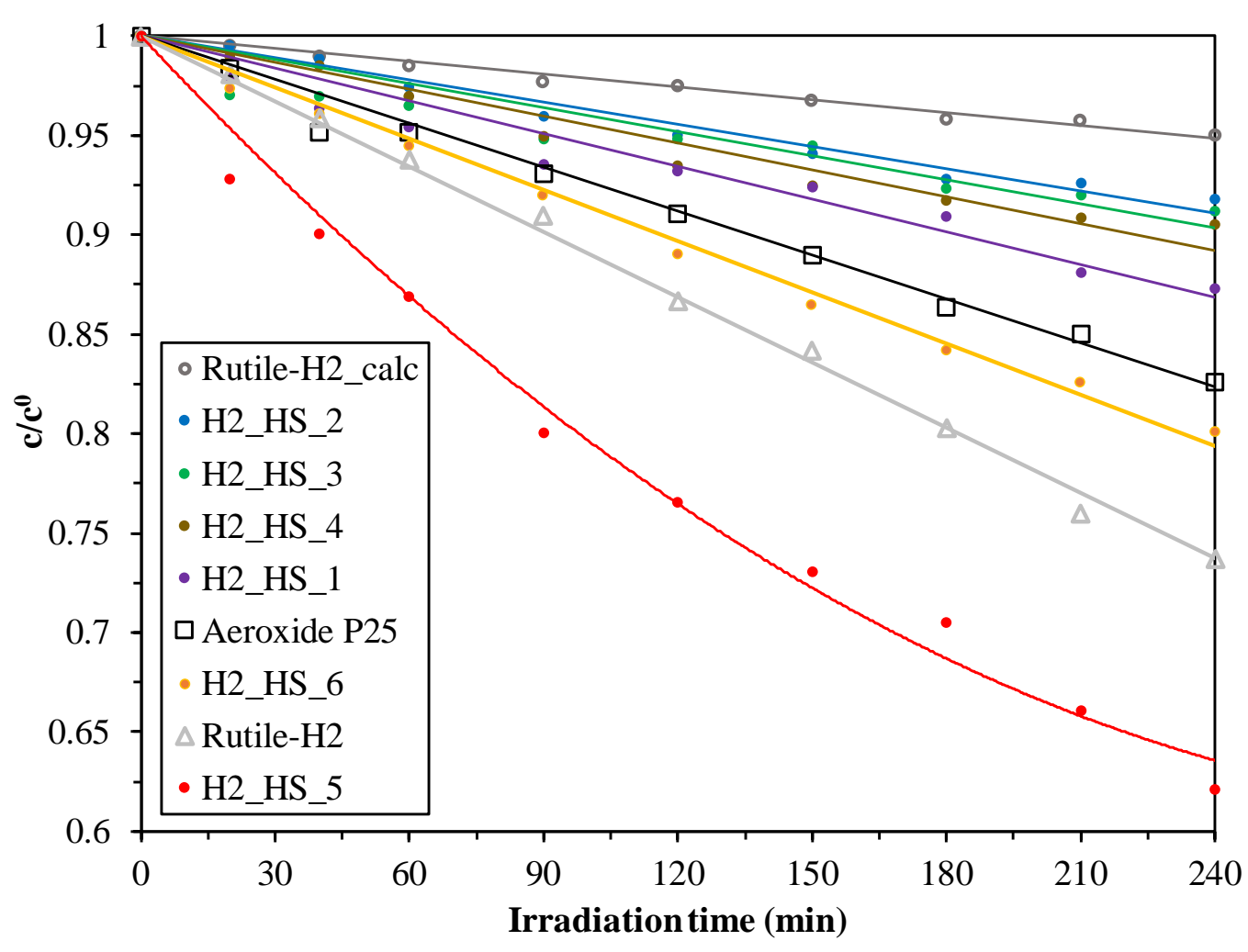

Figure 29 Photocatalytic decomposition of phenol solutions under visible light irradiation $\left(\right.$ Cphenol $\left.=0.1 \mathrm{mM}, \mathrm{CTiO}_{2}=1.0 \mathrm{~g} \cdot \mathrm{L}^{-1}\right)$.

Samples with higher anatase content (H2_HS_1-4) possessed significantly lower photocatalytic efficiency compared to samples with higher rutile content (H2_HS_5-6), as it was expected. H2_HS_5 $\mathrm{TiO}_{2}$ had outstanding photocatalytic performance, exceeding the photocatalytic activity of Aeroxide P25 and even our previous, peroxo group containing Rutile-H2 $\mathrm{TiO}_{2}$ with high visible light activity, which could be explained by its rutile content, and more importantly, its morphology, resulting in presumably the enhanced utilization of light source. Based on these results, it was deduced, that the activity gain caused by the hollow structural morphology significantly over-compensated the activity loss caused by the disappearance of peroxo groups during calcination. Moreover, H2_HS_5 TiO2 possessed not only the highest absolute photocatalytic activity, but the lowest specific surface area (out of the $\mathrm{TiO}_{2}$ series synthesized by the application of CSs), thus, the highest surface normalized photocatalytic efficiency as well (8 times higher than the Rutile-H2; see in Table 6). It is important to highlight, that the photocatalytic activity of all samples possessing hollow structural morphology surpassed the photocatalytic efficiency of Rutile$\mathrm{H} 2$ _calc $\mathrm{TiO}_{2}$, which can be considered as the appropriate reference in terms of measuring 
the activity gain by the morphology, since it was synthesized similarly (including the calcination step), just without the application of carbon sphere templates.

The stability of the sample H2_HS_5 - possessing the highest photocatalytic activity - was investigated by XRD and SEM measurements after 3 consecutive phenol degradation tests, and this sample was named as 'H2_HS_5_re'. During the 3 runs the photocatalytic efficiency of H2_HS_5_re did not decrease; the standard deviation was less than 2\%. Based on the XRD diffractograms sample H2_HS_5_re entirely retained its initial crystal phase composition (80\% rutile and 20\% anatase) and its morphology as well (Appendix 4), proving this catalyst to be particularly stable.

Lastly, it is important to mention, that although samples H2_HS_5 and H2_HS_6 possessed very similar characteristic properties (high rutile content, similar morphology, band gap, crystallite size and specific surface area), still, sample H2_HS_5 was nearly twice as efficient compared to H2_HS_6, despite the latter having larger specific surface area and higher rutile content (the only difference was that in the case of H2_HS_5, carbon spheres were eliminated in muffle furnace without additional air supply, whereas in the case of H2_HS_6 tube furnace was used with constant air supply). In order to ascertain the cause of this result, these two samples (together with $\mathrm{H} 2 \_H S \_2 \mathrm{TiO}_{2}$ as a reference sample with low photocatalytic activity) were characterized further by XPS measurements.

\subsubsection{Further characterization and establishing connection between the results of morpho-structural characterization and photocatalytic activity}

The studied materials were obtained by a synthesis process which involved two crystallization steps, the first being the deposition of titania onto the surface of the carbon spheres and its subsequent crystallization at $55^{\circ} \mathrm{C}$ for $48 \mathrm{~h}$, while the second one was the removal of the carbon templates by calcination, while a recrystallization process occurred. The mentioned two synthesis steps are rather complex, suggesting that a more focused analysis was needed concerning the obtained nanostructures' surface quality ${ }^{1}$. In a lot of cases, the main reason behind the varying photoactivity of a catalyst is the presence of different induced defects (e.g. $\mathrm{Ti}^{3+}$ [198]), which may act as active centers on the surface of the catalyst, therefore, in the first instance Ti2p spectra (Figure 30a) of the chosen materials

\footnotetext{
${ }^{1}$ The concertation of a specific element was given in at $\%$ in the case of all samples, while the distribution of specific oxidation states is given in \% from the total amount of that specific element.
} 
were investigated. It was found, that $\mathrm{Ti}^{4+}\left(458.3 \mathrm{eV}-2 \mathrm{p}^{1 / 2}, 464.1 \mathrm{eV}-2 \mathrm{p}^{3 / 2}\right)$ was the main Ti species identified, accompanied by a small amount of $\mathrm{Ti}^{3+}$ centers $\left(456.8 \mathrm{eV}-2 \mathrm{p}^{1 / 2}, 462.3\right.$ $\mathrm{eV}-2 \mathrm{p}^{3 / 2}$ ) which is an important species possibly contributing to achieve high photocatalytic activity [196]. The content of $\mathrm{Ti}^{4+}$ and $\mathrm{Ti}^{3+}$ was nearly the same in all samples (2.24-2.49\% $\mathrm{Ti}^{3+}$ and $97.76-97.51 \% \mathrm{Ti}^{4+}$ ), pointing out that possible differences in the photoactivity may lie elsewhere. The O1s spectra (Figure 30b) revealed that low binding energy oxygen (527.5 $\mathrm{eV}$ ) was present, which is usually associated with $\mathrm{Ti}^{3+}$ centers [194], but the content of this species was nearly identical in the samples. Furthermore, surface $\mathrm{OH}$ associated oxygen $(531.3 \mathrm{eV})$ and lattice oxygen $(529.7 \mathrm{eV})$ were also detected, which are usual components in such samples. The first significant difference between the three samples was the higher content of OH_O (8.97\% compared to 5.02\% and 4.97\%, respectively) in sample H2-HS_2, suggesting a higher water affinity (hydrophilicity) [194], a potential parameter which might define the photocatalytic activity of this sample.

The elimination of organic compounds and carbon can induce interesting structural changes [117, 194, 196], including surface sensitization, carbon deposits and optical response changes. Residual carbon can also have various effects on the photocatalytic activity of titania [117]. Since the synthesis of the investigated samples included the elimination of CSs, it was crucial to investigate the C1s spectra of the samples in detail. In the C1s XPS spectra (Figure 30c, $\mathbf{d}$ and e) three carbon species/bond types were identified: $\mathrm{C}-\mathrm{C}$ at $284.5 \mathrm{eV}, \mathrm{C}-\mathrm{O}-\mathrm{C}$ at $286.0 \mathrm{eV}$ and $\mathrm{O}-\mathrm{C}=\mathrm{O}$ at $288.6 \mathrm{eV}$. 

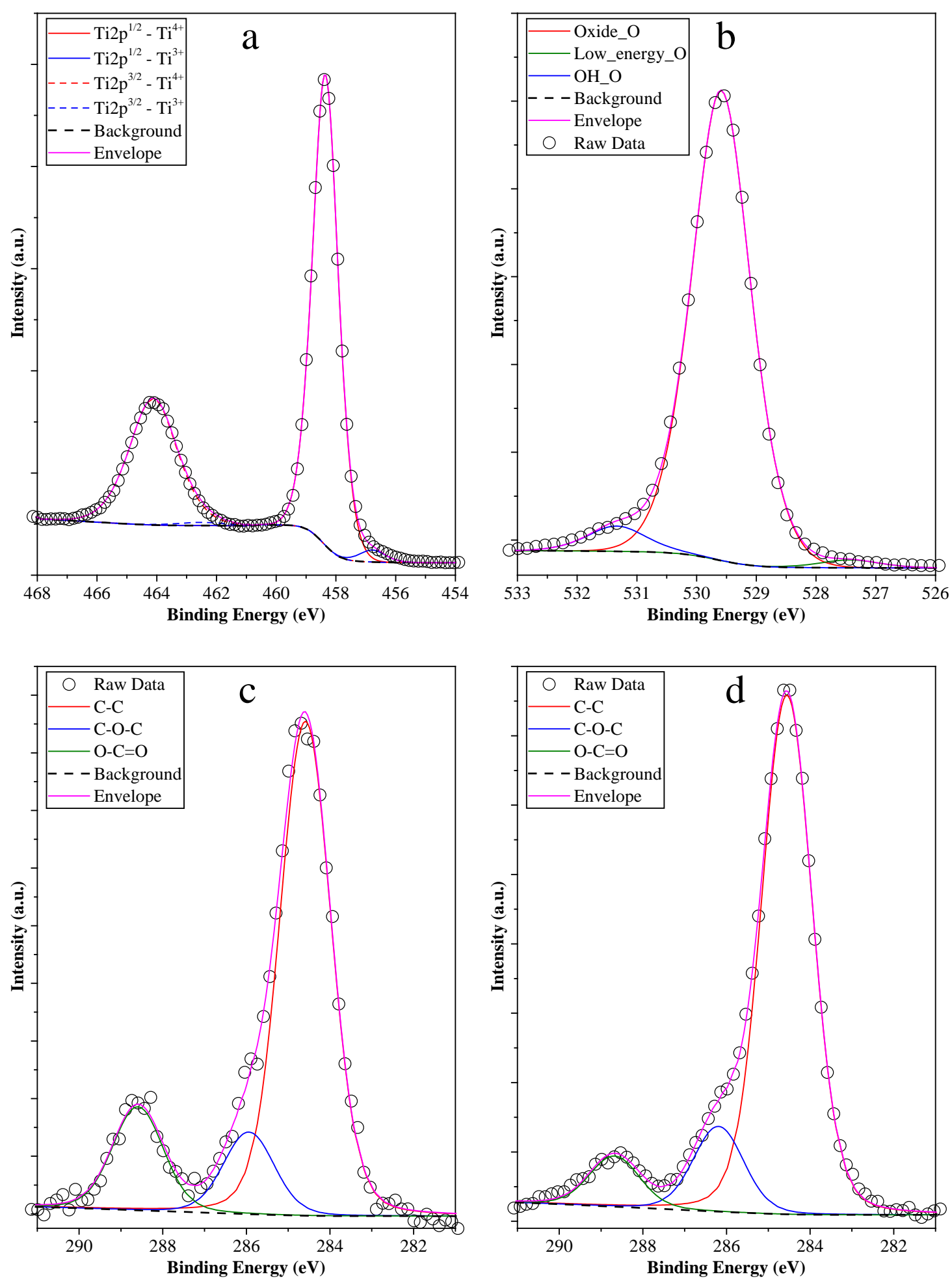


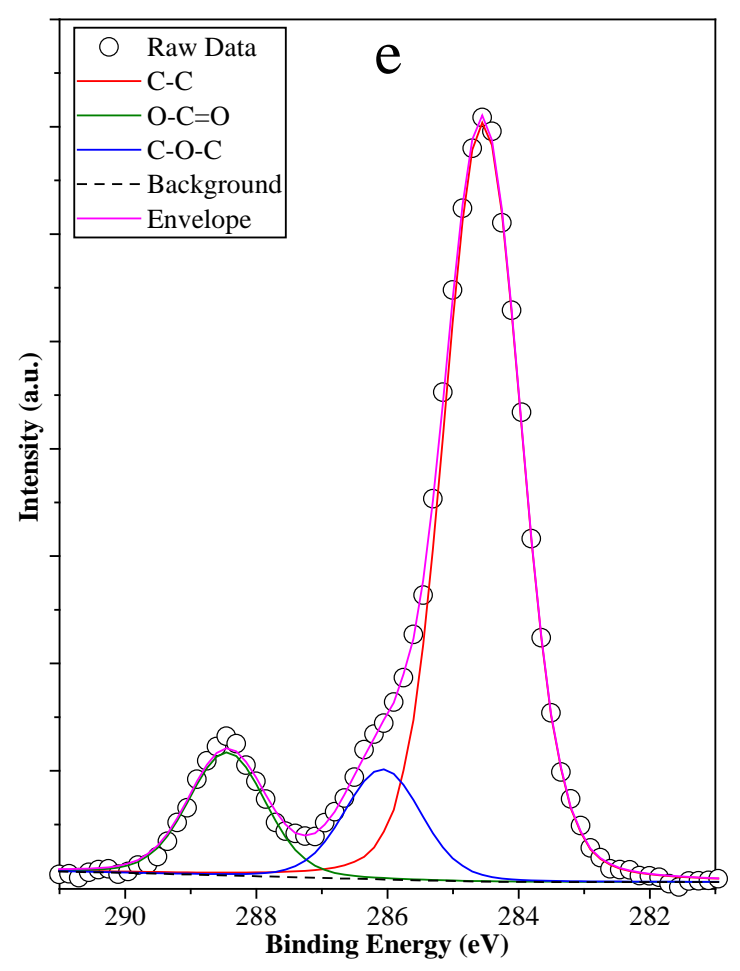

Figure 30 The core XPS spectra of samples H2_HS_5 (a - Ti2p; b-O1s; c - C1s), H2_HS_2 (d - C1s) and H2_HS_6 (e-C1s) pointing out the influence of the calcination and/or the quality of the carbon spheres on the surface chemistry of the titania hollow spheres.

As the hollow nanostructures were obtained by the removal of carbon, the oxidized carbon's presence was not a surprise. However, in sample H2_HS_5 the amount of oxidized carbon was higher (15.19\%) than in H2_HS_2 (7.72\%) and H2_HS_6 (9.78\%). The more pronounced presence of oxidized carbon in the most efficient H2_HS_5 sample points out, that the removability of carbon spheres was higher in this case, reinforced also by the lower content of total carbon (8.91 at\%, compared to sample H2_HS_2 - 20.18 at\% and H2_HS_6 - 30.72 at\%). The presence of carbon at such concentration values is known and not unprecedented, even without applying additional carbon source, as it was shown in a previous paper of our research group [194].

Comparing sample H2_HS_6 with H2_HS_5 the following observations were made:

- The total amount of carbon in sample H2_HS_6 (30.72 at\%) was determined to be higher than in sample H2_HS_5 (8.91 at\%).

- In sample H2_HS_5, the ratio of O-C=O bonds was higher (15.18\% from the total amount of carbon species) than in the case of H2_HS_6 (12.38 \% from the total 
amount of carbon species), pointing out a more efficient carbon removal (oxidation) process in the case of the latter sample.

- The above listed observations emphasize the fact that as the carbon was more efficiently eliminated from the samples (shown by the lower carbon content and higher amount of oxidized carbon species), the photocatalytic activity was higher (sample H2_HS_6 possessed only 52.6\% of the photocatalytic activity of sample H2_HS_5), because in the case of the samples with lower photocatalytic activity, the surface available for the photocatalytic process could be partially blocked and therefore more hydrophobic as well. Simultaneously, if the ratio of the $\mathrm{O}-\mathrm{C}=\mathrm{O}$ in the surface deposited carbon was higher, again supports the observed activity increase, since polar functional groups facilitate the direct contact between water (the matrix of the photocatalytic process) and the surface of the photocatalyst.

\subsection{Noble metal deposition}

Although enhancing the photocatalytic activity of Rutile-H2 $\mathrm{TiO}_{2}$ via morphological modification was successful, the resulting hollow spherical morphology was not perfectly homogeneous. Based on the SEM images we managed to synthesize regular spherical $\mathrm{TiO}_{2}$ s, which indeed had an inner cavity, presumably resulting in the enhancement of the light trapping properties of these $\mathrm{TiO}_{2}$-s to a certain extent. However, based on the subsequent TEM analysis, a significant portion of these $\mathrm{TiO}_{2}$ hollow structures were still dense (nonhollow), excluding the hollow cavity visible in the SEM figures. Thus, in the next section another synthesis method was applied for the fabrication of truly hollow spherical $\mathrm{TiO}_{2}-\mathrm{s}$, and the $\mathrm{TiO}_{2}$ sample possessing the best characteristic was selected for the deposition of $\mathrm{Au}$ and Pt noble metals for the further enhancement of its photocatalytic activity. This kind of combination of photocatalytic-activity-enhancing methods (i.e. combining morphological modification with noble metal deposition) is relatively novel; the number of publications in this topic is scarce [143, 161, 165, 239].

\subsubsection{Characterization}

\subsubsection{Characterization of $\mathrm{TiO}_{2}$ hollow spheres}

Firstly, CSs were prepared then purified via centrifugation (as per detailed in the previous sections) using various solvents (acetone or ethanol) because based on our previous 
experiences and the publication of Mahyar and Amani-Ghadim [237], applying solvents of different polarity can result in the formation of titanium dioxides with different crystal phase compositions and characteristics, making the investigation of both acetone and ethanol usage worthwhile. By the utilization of these $\mathrm{CSs}$, $\mathrm{TiO}_{2}$-HSs were prepared (Table 7) applying different calcination temperatures $\left(500,800^{\circ} \mathrm{C}\right)$ using tube furnace under constant air supply (accordingly to the synthesis method of Ao et al. [155]), which were characterized by XRD, SEM and TEM in order to determine which $\mathrm{TiO}_{2}-\mathrm{HS}$ possesses the best characteristics to be used as the base material for the deposition of noble metals.

\begin{tabular}{|c|c|c|c|c|c|}
\hline Sample name & \multicolumn{2}{|c|}{$\begin{array}{c}\text { CS } \\
\text { purification } \\
\text { solvent }\end{array}$} & $\begin{array}{c}\text { Calcination } \\
\text { temperature } \\
\left({ }^{\circ} \mathrm{C}\right) \\
\end{array}$ & $\begin{array}{c}\text { Anatase } \\
\text { (wt \%) }\end{array}$ & $\begin{array}{l}\text { Rutile } \\
\text { (wt\%) }\end{array}$ \\
\hline $\mathrm{TiO}_{2}$ no_HSS ${ }_{500}^{\mathrm{Ac}}$ & \multicolumn{2}{|c|}{ acetone } & 500 & 97 & 3 \\
\hline $\mathrm{TiO}_{2} \mathrm{HS}_{500}^{\mathrm{Ac}}$ & \multicolumn{2}{|c|}{ acetone } & 500 & 87 & 13 \\
\hline $\mathrm{TiO}_{2} \mathrm{HS}_{800}^{\mathrm{Ac}}$ & \multicolumn{2}{|c|}{ acetone } & 800 & - & 100 \\
\hline $\mathrm{TiO}_{2} \mathrm{HS}^{\mathrm{EtOH}}{ }_{500}$ & \multicolumn{2}{|c|}{ ethanol } & 500 & 96.6 & 3.4 \\
\hline $\mathrm{TiO}_{2} \mathrm{HS}^{\mathrm{EtOH}}{ }_{800}$ & \multicolumn{2}{|c|}{ ethanol } & 800 & 12.5 & 87.5 \\
\hline $\mathrm{TiO}_{2} \mathrm{HS}^{\mathrm{Ac}}{ }_{500}-\mathrm{Au}$ & \multicolumn{2}{|c|}{ acetone } & 500 & 90 & 10 \\
\hline $\mathrm{TiO}_{2} \mathrm{HS}^{\mathrm{Ac}}{ }_{500}-\mathrm{Pt}$ & \multicolumn{2}{|c|}{ acetone } & 500 & 91.9 & 8.1 \\
\hline e name & $\begin{array}{c}D_{A} \\
(\mathrm{~nm})\end{array}$ & $\begin{array}{c}D_{R} \\
(n m)\end{array}$ & $\begin{array}{c}\text { Diameter } \\
(\mathbf{n m})\end{array}$ & Circularity & $\begin{array}{c}\text { Specific } \\
\text { surface area } \\
\left(\mathbf{m}^{2} \mathbf{g}^{-1}\right) \\
\end{array}$ \\
\hline $\mathrm{TiO}_{2}$ no_HHS ${ }_{500}^{\mathrm{Ac}}$ & 35 & 66.9 & 1313 & 0.99 & $\sim 6$ \\
\hline $\mathrm{TiO}_{2} \mathrm{HS}_{500}^{\mathrm{Ac}}$ & 26.5 & 30.1 & 1198 & 0.99 & $\sim 6$ \\
\hline $\mathrm{TiO}_{2} \mathrm{HS}^{\mathrm{Ac}}{ }_{800}$ & - & 28.3 & 1129 & 0.94 & $\sim 6$ \\
\hline $\mathrm{TiO}_{2} \mathrm{HS}^{\mathrm{EtOH}}{ }_{500}$ & 18.1 & 20.9 & 948 & 0.98 & $\sim 6$ \\
\hline $\mathrm{TiO}_{2 \_} \mathrm{HS}_{800}^{\mathrm{EtOH}}$ & 35.1 & 32.4 & 1122 & 0.93 & $\sim 6$ \\
\hline $\mathrm{TiO}_{2} \mathrm{HS}^{\mathrm{Ac}}{ }_{500}-\mathrm{Au}$ & 22.2 & 20.5 & 1635 & 0.98 & $\sim 6$ \\
\hline $\mathrm{TiO}_{2} \mathrm{HS}_{500}^{\mathrm{Ac}}-\mathrm{Pt}$ & 22.9 & 29 & 1333 & 0.98 & $\sim 6$ \\
\hline
\end{tabular}

Table 7 Crystal phase compositions, diameters (median), circularities and specific surface areas of the $\mathrm{TiO}_{2}-\mathrm{HSs}$ samples.

The SEM and TEM micrographs of the $\mathrm{TiO}_{2}-\mathrm{HSs}$ are shown in Fig. 31. Based on the SEM measurements it was observed that the samples synthesized at similar conditions (Fig. 31a with Fig. 31b and Fig. 31c with Fig. 31d), i.e. same solvent and calcination temperature, similar characteristics could be observed (similar morphology and diameter/circularity values) (Table 7). Based on our previous experiences the most critical step during the synthesis of HSs via template removal is the elimination of CSs by calcination. In the case 


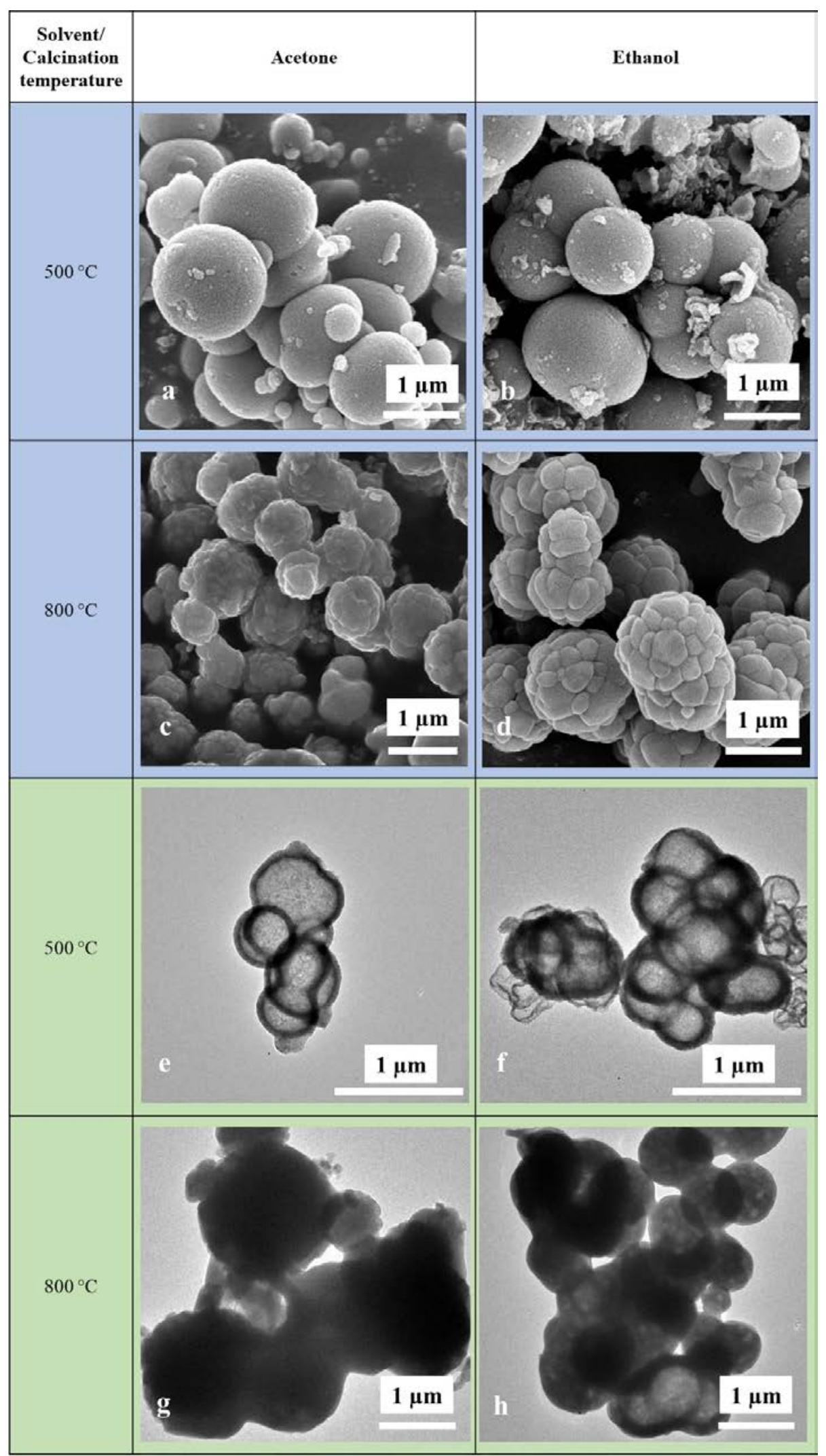

Figure 31 SEM micrographs of samples $\mathrm{TiO}_{2} \mathrm{HS}^{\mathrm{Ac}_{500}}$ (a), $\mathrm{TiO}_{2} \mathrm{HS}^{\mathrm{EtOH}}{ }_{500}$ (b), $\mathrm{TiO}_{2} \mathrm{HS}^{\mathrm{Ac}} 800$ (c) $\mathrm{TiO}_{2} \mathrm{HS}^{\mathrm{EtOH}_{800}}$ (d) and their corresponding TEM figures (e-h, respectively). 
of samples calcined at $500{ }^{\circ} \mathrm{C}$ (Fig. 31a and Fig. 31b) well-defined spheres were observed possessing near perfect morphology, which were not damaged during calcination. The circularity values, medians and the diameter distribution histograms are summarized in Table 7 and Appendix 5, respectively. Based on the TEM images of the samples calcined at $500{ }^{\circ} \mathrm{C}$ (Fig. 31e and Fig. 31f) it was confirmed that they had regular hollow cavities, as intended. The theoretical thickness of the $\mathrm{TiO}_{2}$ shell - evaluated from the quantities of the reactants - was calculated to be $70 \mathrm{~nm}$ from the relative weight fractions of $\mathrm{CS}$ and $\mathrm{TiO}_{2}$ coating (determined from the volume and density of these species). This value is in reasonably good accordance with the one obtained from the TEM micrographs, which was calculated to be $\sim 60 \mathrm{~nm}$. Increasing the calcination temperature to $800^{\circ} \mathrm{C}$ (Fig. 31c and Fig. 31d), resulted in hollow structures with raspberry-like surface, in contrast with the smooth surfaces detected in the previous cases. It was also observed that the high temperature also caused the inner diameter of the hollow cavity to be smaller (Fig. 31g and Fig. 31h), which could be explained as the result of sintering of the nanoparticles [240].

Subsequently, XRD (Fig. 32) and nitrogen adsorption measurements were carried out and the results (crystal phase composition, primary crystallite sizes, specific surface areas) are summarized in Table 7. As expected, the samples calcined at lower temperature $\left(500{ }^{\circ} \mathrm{C}, \mathrm{TiO}_{2} \mathrm{HS}^{\mathrm{Ac}_{500}}\right.$ and $\mathrm{TiO}_{2} \mathrm{HS}^{\mathrm{EtOH}_{500}}$ ) mainly consisted of anatase, while samples calcined at the higher temperature $\left(800{ }^{\circ} \mathrm{C}, \mathrm{TiO}_{2} \mathrm{HS}^{\mathrm{Ac}} 800\right.$ and $\mathrm{TiO}_{2} \mathrm{HS}^{\mathrm{EtOH}_{800}}$ ) contained predominantly rutile phase and larger crystallites.

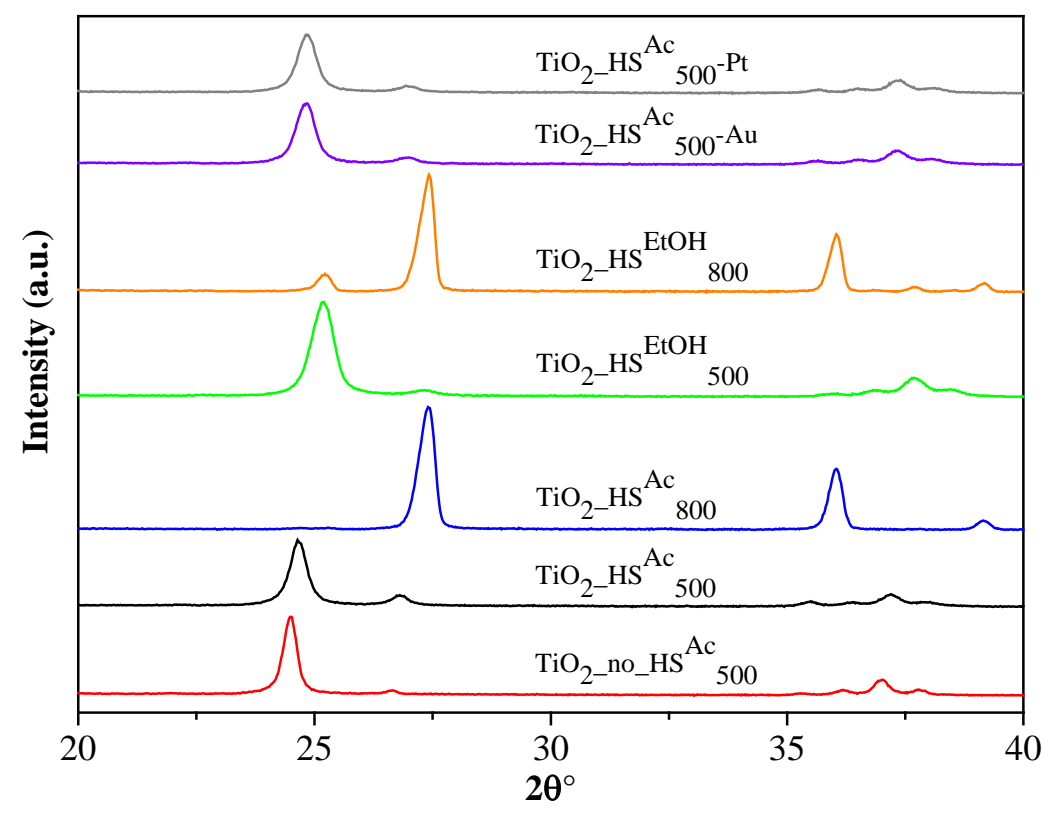

Figure 32 X-ray diffraction patterns of the investigated titania. 
As for the $\mathrm{N}_{2}$ adsorption measurements, despite having relatively low crystallite sizes (18-35 nm), the corresponding specific surface areas were surprisingly low $\left(\sim 6 \mathrm{~m}^{2} \cdot \mathrm{g}^{-1}\right.$ in all cases).

Summarizing these results, it was established, that sample $\mathrm{TiO}_{2} \_\mathrm{HS}^{\mathrm{Ac}}{ }_{500}$ possessed the best characteristics to be used as base material for the determination of photocatalytic activity gain caused by the unique morphology (highest circularity value, regular hollow cavity). Additionally, it was also the most appropriate from the economic point of view, since for the synthesis of this sample the CSs were purified by acetone, which is cheaper than ethanol, and for the elimination of the CSs only $500{ }^{\circ} \mathrm{C}$ temperature was applied making its production the most cost-effective. Therefore, later on, for the deposition of noble metals this sample was selected as base material. Lastly, after the $\mathrm{TiO}_{2} \mathrm{HS}^{\mathrm{Ac}_{500}}$ sample was chosen as base material, a reference sample was also synthesized in the same way just without the application of CS templates (denoted as ' $\mathrm{TiO}_{2}$ no_HS $^{\mathrm{Ac}}{ }_{500}$ '), to investigate the possible effects of the hollow structure. This sample was also examined via SEM and TEM measurements (Fig. 33).

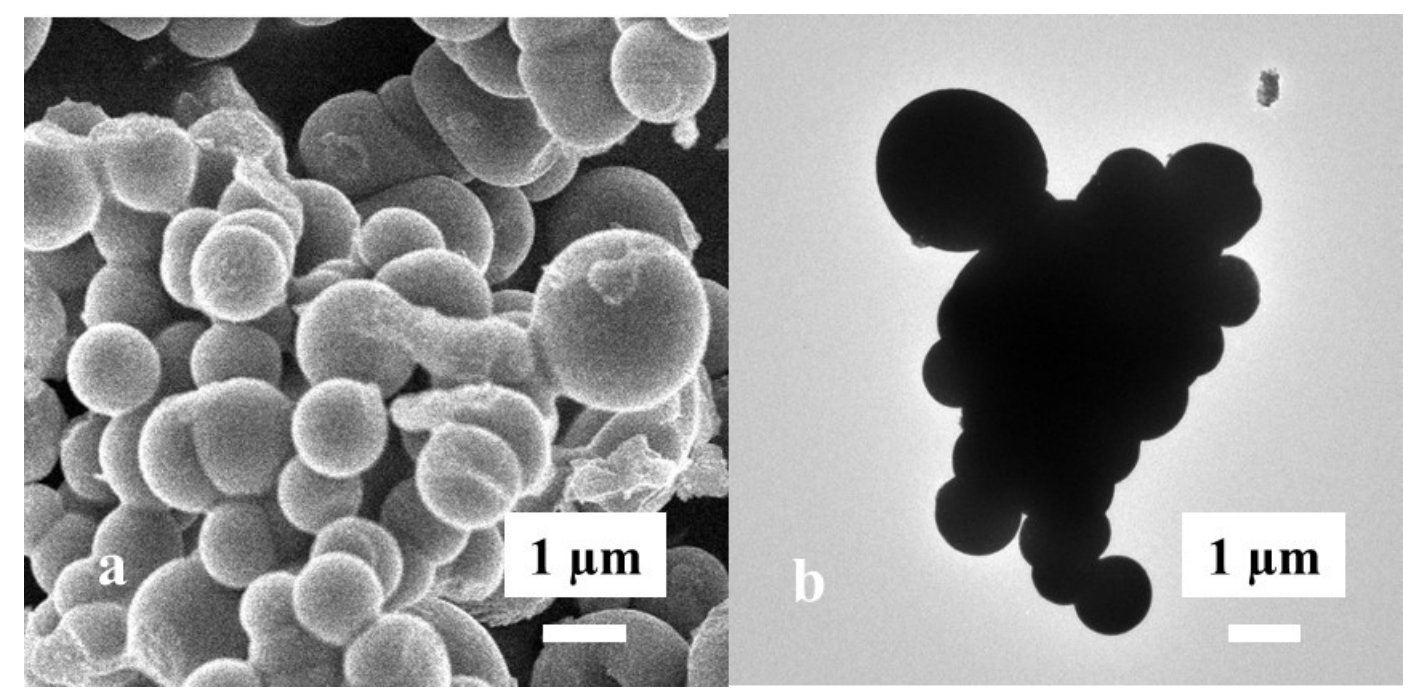

Figure 33 SEM (a) and TEM (b) images of reference non-hollow sample $\mathrm{TiO}_{2}$ no_HS ${ }^{\mathrm{Ac}}{ }_{500}$.

Based on the SEM micrographs (Fig. 33a) it was observed that it also contained welldefined spheres with relatively high diameter $(\sim 1300 \mathrm{~nm})$, comparable to prior samples. Then, this sample was investigated by TEM measurements as well (Fig. 33b) and it was found that it contained solely solid spheres, which, most importantly, makes it most suitable for the investigation of the effects caused by the hollow morphology in the case of our other samples. For the formation of spherical morphology (in the absence of CS templates in the 
case of sample $\mathrm{TiO}_{2}$ no__HS ${ }^{\mathrm{Ac}}{ }_{500}$ ), a plausible explanation can be that according to the Ostwald ripening phenomenon, the formation of larger structures is thermodynamically favored as there are less molecules on the surface in an energetically less stable position, making the formation of the spherical shape (with the least specific surface area) feasible [241]. As for the relatively high diameter (low specific surface area), it was already observed in our research group, that applying a precursor containing relatively long alkyl chains can result in slower hydrolysis making the formation of larger structures favored [242].

\subsubsection{Further characterization of reference $\mathrm{TiO}_{2}-\mathrm{s}$ and $\mathrm{TiO}_{2}-\mathrm{HSs}$ modified with noble metals}

Following the deposition of $0.25 \mathrm{wt} \%$ gold and platinum noble metals on the $\mathrm{TiO}_{2} \mathrm{HS}^{\mathrm{Ac}}{ }_{500}$ sample TEM images were recorded (Fig. 34a and Fig. 34c, respectively). It was observed, that even after the deposition process the regular hollow spherical morphology remained intact, the noble metals were evenly distributed on the surface and no aggregation occurred. Additionally, HRTEM images were utilized to measure the d-spacing of the $\mathrm{TiO}_{2}$ shell, the gold (Fig. 34b) and platinum (Fig. 34d) nanoparticles to confirm their presence. Accordingly, the measured $3.4 \AA$ value was attributed to the $\mathrm{TiO}_{2}$ (101) crystallographic plane, $2.4 \AA$ to the Au (111) plane and $2.0 \AA$ to the Pt (200) plane.

Then, XRD measurements were carried out to determine the influence of the chemical deposition process on the properties of the $\mathrm{TiO}_{2} \_\mathrm{HS}^{\mathrm{Ac}}{ }_{500}$ base material (Fig. 32, Table 7). It was found that after the deposition process the noble metal-containing samples largely retained their crystal phase composition as expected. The rutile crystal phase content of $\sim 8-13 \mathrm{wt} \%$ of the base material and noble metal-containing samples could be beneficial in terms of the photocatalytic activity of these samples similarly to the well-known commercial reference P25 $\mathrm{TiO}_{2}$ [192]. The non-hollow $\mathrm{TiO}_{2}$ no__HS ${ }^{\mathrm{Ac}_{500}}$ sample also contained rutile crystal phase in $3 \mathrm{wt} \%$. 


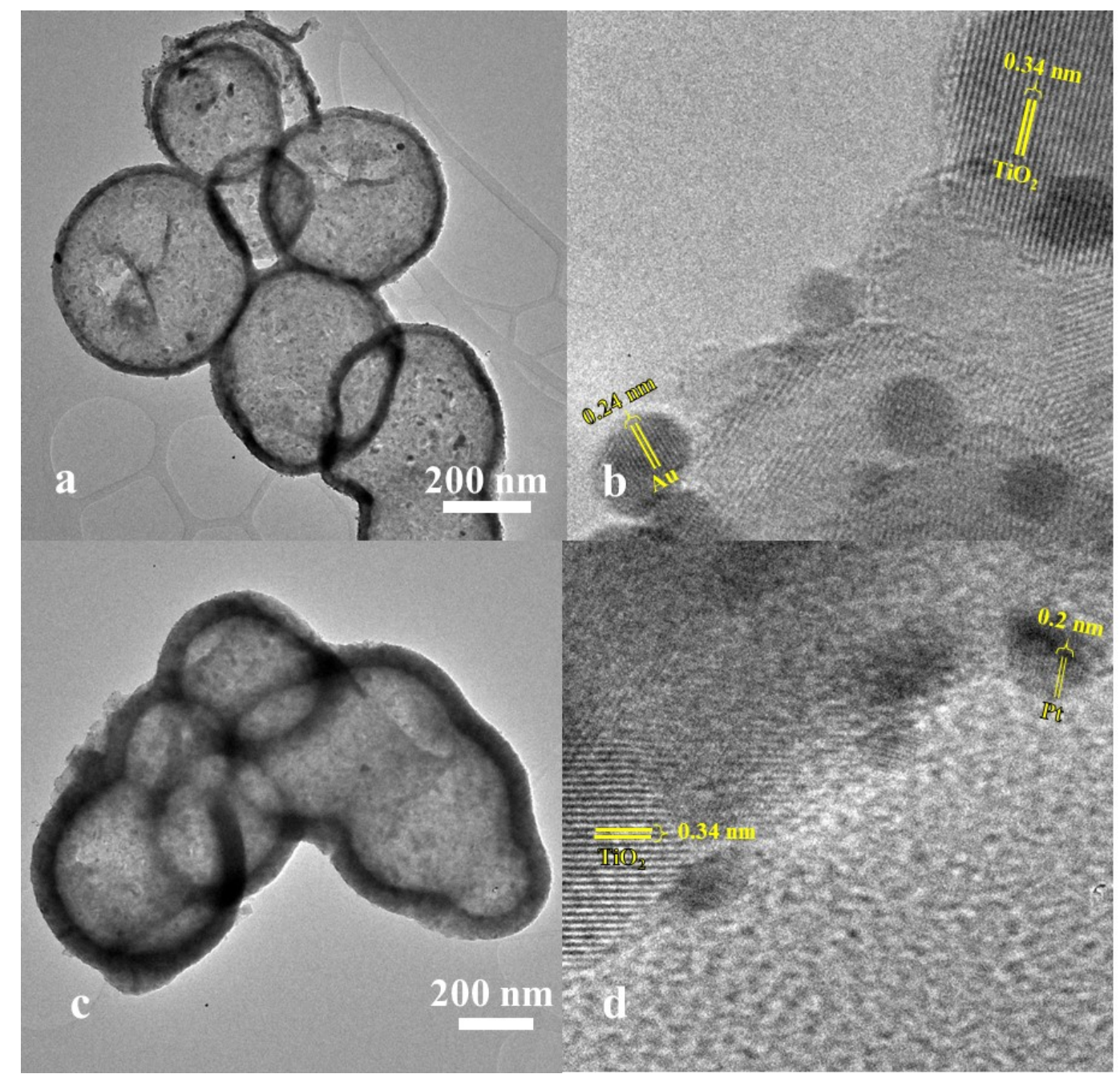

Figure 34 TEM images of samples $\mathrm{TiO}_{2} \mathrm{HS}^{\mathrm{Ac}}{ }_{500}-\mathrm{Au}(\mathrm{a}, \mathrm{b})$ and $\mathrm{TiO}_{2} \mathrm{HS}^{\mathrm{Ac}}{ }_{500}-\mathrm{Pt}(\mathrm{c}, \mathrm{d})$.

As the next step, the light absorption properties were investigated via DR measurements (Fig. 35). The band gap energies were determined from the first derivative spectra of the $\mathrm{TiO}_{2}-\mathrm{s}$, due to it being more precise, as mentioned before [3]. As expected, rutile phase $\mathrm{TiO}_{2}-\mathrm{s}$ possessed lower band gaps (3.02 eV for $\mathrm{TiO}_{2} \mathrm{HS}^{\mathrm{Ac}_{800}}$ and $\mathrm{TiO}_{2} \mathrm{HS}^{\mathrm{EtOH}_{800}}$ ) compared to the anatase phase $\mathrm{TiO}_{2}-\mathrm{S}$ (3.1 eV for $\mathrm{TiO}_{2}$ no_HS ${ }^{\mathrm{Ac}}{ }_{500}$, $\mathrm{TiO}_{2} \mathrm{HS}^{\mathrm{EtOH}_{500}}$ and $3.14 \mathrm{eV}$ for $\mathrm{TiO}_{2} \mathrm{HS}^{\mathrm{Ac}}{ }_{500}$ ). The band gap after noble metal deposition (3.13 eV for both $\mathrm{TiO}_{2} \mathrm{HS}^{\mathrm{Ac}}{ }_{500}-\mathrm{Au}$ and $\mathrm{TiO}_{2} \mathrm{HS}^{\mathrm{Ac}}{ }_{500}-\mathrm{Pt}$ ) did not change significantly compared to the base material $\left(\mathrm{TiO}_{2} \mathrm{HS}^{\mathrm{Ac}}{ }_{500}, 3.14 \mathrm{eV}\right)$. The inflection point at $\sim 542 \mathrm{~nm}$ in the derivative spectrum can be attributed to the plasmon resonance of the gold nanoparticles in the case of sample $\mathrm{TiO}_{2}-\mathrm{HS}^{\mathrm{Ac}}{ }_{500}-\mathrm{Au}$. The surface properties were examined by FT-IR measurements (Fig. 36). Bands at 424, 515 and $620 \mathrm{~cm}^{-1}$ can be attributed to the transverse optical vibrations of the Ti-O bonds [190, 206, 243]. 


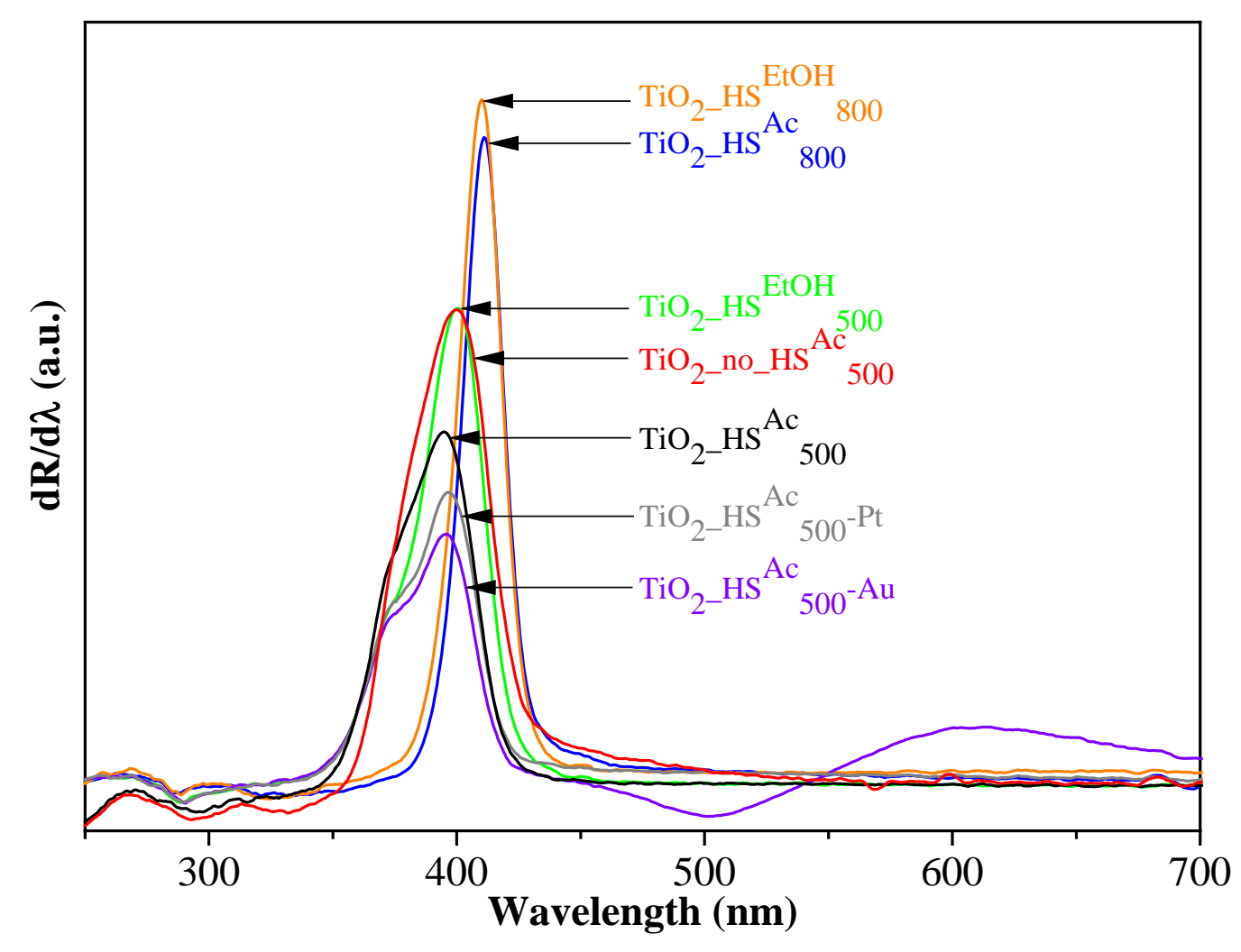

Figure 35 First order derivative DR spectra of the as-prepared photocatalysts.

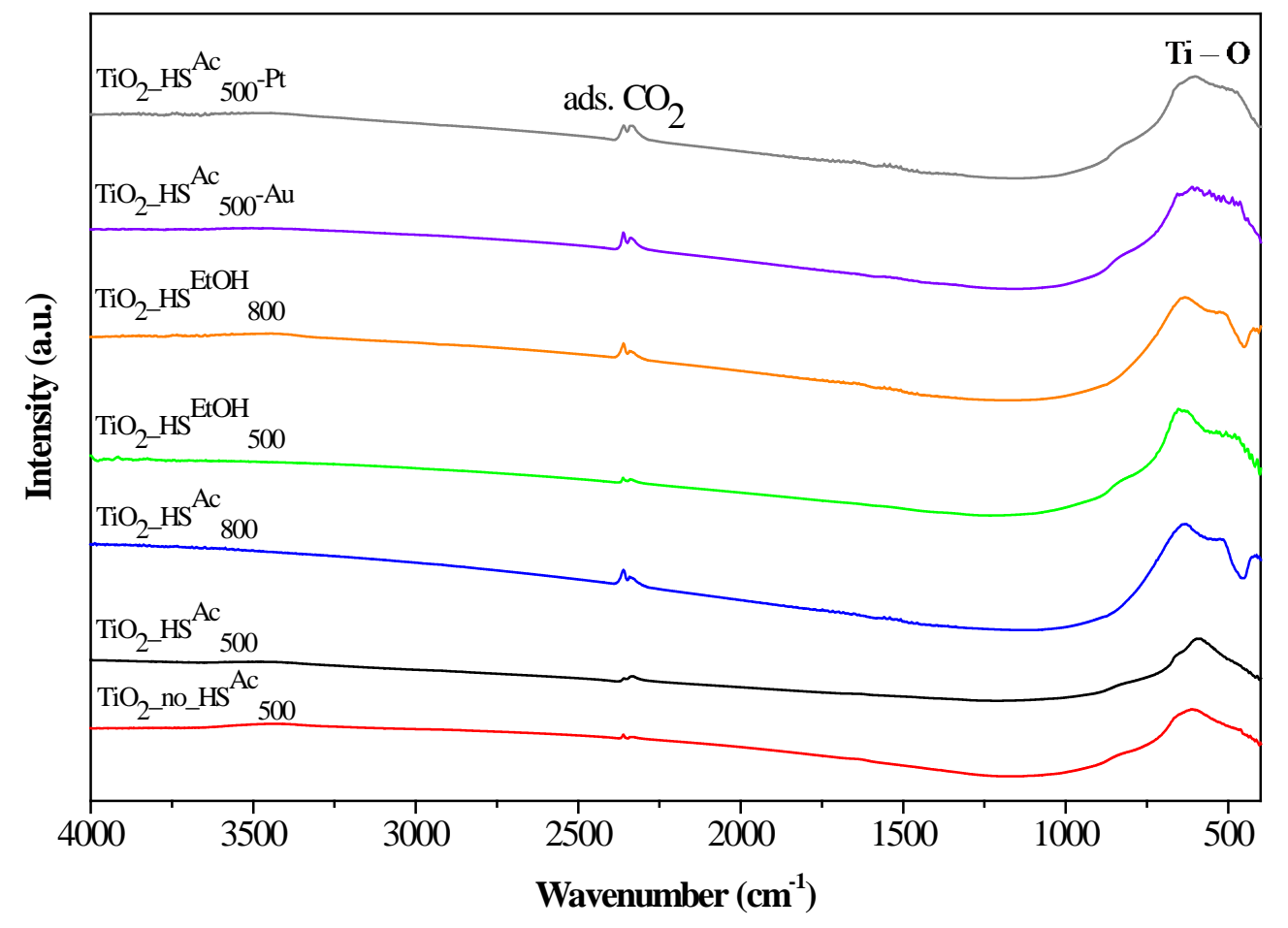

Figure 36 FT-IR spectra of the investigated photocatalysts. 
The shape of these bands varied in accordance with the different crystal phases; anatase has less defined $\mathrm{Ti}-\mathrm{O}$ stretch band as it possesses less ordered structure (compared to rutile), consequently, in the case of mixed crystal phase compositions, the infrared absorption bands also represented this transmission between the two crystal phases, similarly as before [238]. The doublet at 2340, $2358 \mathrm{~cm}^{-1}$ is characteristic of adsorbed $\mathrm{CO}_{2}$ [187]. Additional bands which could be ascribed to leftover carbon from either the $\mathrm{TiO}_{2}$ precursor or the CS templates were not observed, from which it was concluded that during the calcination process these were entirely eliminated from the system.

\subsubsection{Photocatalytic activity}

The photocatalytic activity of the non-hollow, spherical reference sample $\left(\mathrm{TiO}_{2}\right.$ no_HS $\left.^{\mathrm{Ac}}{ }_{500}\right)$, the base material $\left(\mathrm{TiO}_{2} \mathrm{HS}^{\mathrm{Ac}}{ }_{500}\right)$ and the noble metal-containing samples $\left(\mathrm{TiO}_{2} \mathrm{HS}^{\mathrm{Ac}}{ }_{500}-\mathrm{Au}\right.$ and $\left.\mathrm{TiO}_{2} \mathrm{HS}^{\mathrm{Ac}}{ }_{500}-\mathrm{Pt}\right)$ was investigated by the photocatalytic degradation of phenol and oxalic acid under UV and visible light irradiation and the results were summarized in Fig. 37 (UV irradiation) and Appendix 6 (visible light irradiation).
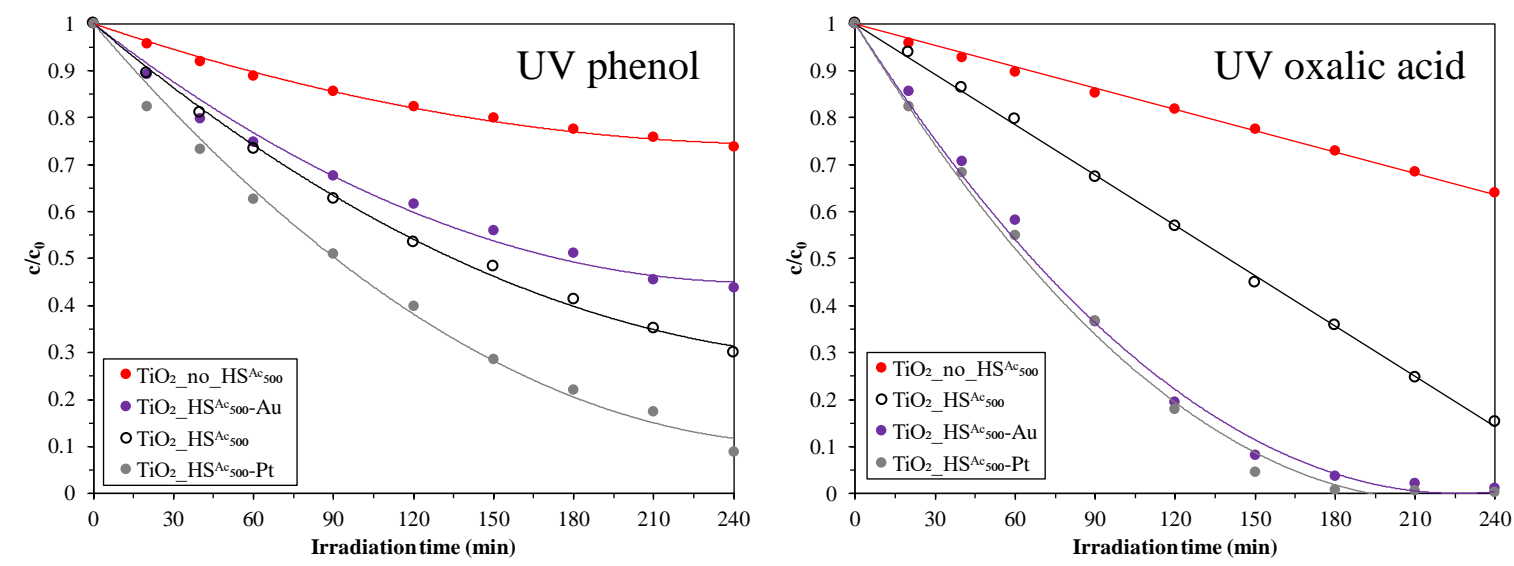

Figure 37 Photocatalytic activity of the investigated photocatalysts under UV light irradiation.

In the case of the spherical, but non-hollow $\mathrm{TiO}_{2} \_n o \_H S^{\mathrm{Ac}_{500}}$ reference sample negligible photocatalytic activity was observed under visible light irradiation ( 3-4\% model pollutants were degraded) and by applying UV irradiation 26\% phenol and 36\% oxalic acid were degraded after the 240-minute-long measurements.

As the next step, the hollow spherical base material $\left(\mathrm{TiO}_{2} \_\mathrm{HS}^{\mathrm{Ac}}{ }_{500}\right)$ was investigated, to determine the possible achievable effects of the unique morphology on the photocatalytic activity. In almost every case, the enhancement of photocatalytic activity was observed 
(except in the case of oxalic acid degradation under visible light irradiation). In the case of visible light irradiation only negligible differences were observed; however, under UV light irradiation a notable $166 \%$ and $135 \%$ enhancement was detected for phenol and oxalic acid degradation compared to the non-hollow reference $\mathrm{TiO}_{2}$.

By the deposition of noble metals on the surface of the hollow spherical base catalyst $\mathrm{TiO}_{2} \mathrm{HS}^{\mathrm{Ac}}{ }_{500}$, in almost every case the photocatalytic activity increased (except in the case of $\mathrm{TiO}_{2} \mathrm{HS}^{\mathrm{Ac}}{ }_{500}-\mathrm{Au}$ during the decomposition of phenol under UV light irradiation). Applying visible light irradiation 156\% and 66\% increase were observed for phenol for sample $\mathrm{TiO}_{2}-\mathrm{HS}^{\mathrm{Ac}}{ }_{500} \_\mathrm{Au}$ and $\mathrm{TiO}_{2} \mathrm{HS}^{\mathrm{Ac}}{ }_{500}-\mathrm{Pt}$, respectively, and $780 \%$ and $200 \%$ for oxalic acid, respectively. At the same time, in the case of UV irradiation these values were $-20 \%$, $41 \%$ and $18 \%$, $18 \%$, respectively.

\subsubsection{Establishing connection between the results of morpho-structural characterization and photocatalytic activity}

For the explanation of the obtained results, numerous factors can be considered, as it was established in the literature that the following parameters play an important role in the photocatalytic activity of noble metal-deposited titania: (i) properties of the $\mathrm{TiO}_{2}$ (crystallite size, specific surface area, crystal phase composition, surface features, etc.) [56, 57, 162, 174]; (ii) properties of the noble metal (size, shape, amount) [40, 163, 164, 173]; (iii) properties of the model pollutants (adsorption ability, charge carrier-scavenging attributes, features of intermediates, etc.) [162-164, 174]; (iv) the emission spectrum of the light source and the temperature during the photocatalytic experiments [44, 121, 244].

Generally, it can be said that the investigated titania decomposed oxalic acid to a greater degree compared to phenol. It is well-known, that phenol is a poorly adsorbing compound and the degradation of pollutants takes place by the utilization of the generated - $\mathrm{OH}$ radicals; moreover, the forming degradation intermediates with different adsorption properties can also block the active sites of the photocatalyst hindering the further degradation process. Conversely, oxalic acid can adsorb to the surface of $\mathrm{TiO}_{2}$ extremely well facilitating its degradation by the generated charge carriers; furthermore, oxalic acid is a hole scavenger resulting in the efficient separation/increased lifespan of electrons [164].

In the case of oxalic acid degradation, the addition of $\mathrm{Au}$ and Pt nanoparticles resulted in the increase of photocatalytic activity in all cases (under both $\mathrm{UV}$ and visible light irradiation), reaching nearly $100 \%$ degradation efficiency in the former case. This result is 
in good accordance with literature data where the same results were observed in the case of commercial (predominantly) anatase phase $\mathrm{TiO}_{2}$-s (Aldrich anatase, Aeroxide P25) [162, 164]. The photocatalytic activity enhancement of $\mathrm{TiO}_{2}-\mathrm{HS}^{\mathrm{Ac}}{ }_{500}-\mathrm{Pt}$ can be explained by a double charge trapping mechanism: oxalic acid acts as a hole scavenger, whereas the $\mathrm{Pt}$ separates the electron from the $\mathrm{TiO}_{2}$ nanoparticle [163]. In the case of $\mathrm{TiO}_{2} \mathrm{HS}^{\mathrm{Ac}}{ }_{500}-\mathrm{Au}$ the photocatalytic activity enhancement can be associated with the results of our previous work, where the highest degree of photocatalytic activity gain was observed in the presence of spherical gold nanoparticles [40], similar to the present results (Fig. 34b).

As for the phenol degradation tests, only in the case of $\mathrm{TiO}_{2} \mathrm{HS}^{\mathrm{Ac}}{ }_{500}-\mathrm{Au}$ sample under UV light irradiation was a photocatalytic activity decrease observed, which is in good accordance with the literature data: it is well-known, that in the case of commercial Aeroxide P25 (which has similar crystal phase composition compared to our samples) the deposition of gold nanoparticles results in the photocatalytic activity decrease of phenol under UV light irradiation [40, 69, 162, 173]. However, in the case of the gold-deposited sample under visible light irradiation a photocatalytic activity enhancement was observed, which can be explained by the fact, that the electrons formed by surface plasmon resonance excitation can be efficiently injected into the conduction band of $\mathrm{TiO}_{2}$ leading to enhanced charge separation [245]. The fact, that the surface resonance peak of gold is located in the visible light range, could explain the observed photocatalytic activity enhancement under visible light irradiation. In the case of $\mathrm{TiO}_{2} \mathrm{HS}^{\mathrm{Ac}}{ }_{500}-\mathrm{Pt}$ sample the photocatalytic activity increased after the deposition of platinum under both visible and UV light irradiation. The photocatalytic activity gain in the case of visible light irradiation could be attributed to the rutile content of the sample, since electron trapping by platinum on rutile is much more significant than on anatase [246]. However, the photocatalytic activity enhancement observed in the case of our $\mathrm{TiO}_{2} \mathrm{HS}^{\mathrm{Ac}}{ }_{500}$-Pt sample under UV irradiation could not be attributed to literature data, as normally the deposition of platinum nanoparticles on Aeroxide P25 (possessing similar crystal phase composition) leads to decreased photocatalytic activity [164, 247]. For the deeper understanding of the as-mentioned results in the next paragraph the unique hollow spherical morphology of our samples was taken into account.

It is well-known that light waves (used for the excitation of the photocatalysts) cannot only interact with matter but with each other as well, which is called wave interference. Constructive interference occurs, if the crests of one wave overlap the crests of the other 
wave. For this to happen, the distance between two waves must be equal to an integer multiple of the wavelength and as a result, the crests combine to produce a wave with greater amplitude. If we excite our photocatalyst with such light waves with greater amplitude, then the excitation process can be more efficient resulting in higher photocatalytic activity. Based on this theory, the following steps were taken: the emission spectra of the applied lamps (Fig. 8, bottom right side) were compared to the diameter distribution histograms (Appendix 5) and it was ascertained, that what proportion of the hollow spheres happens to be precisely in the range where the travelled distance is the integer multiple of the wavelength of the emission maxima. For the calculations the most intense domain of the emission spectrum ( $360 \pm 10 \mathrm{~nm}$ ) was taken into account. Then, the percentage of the hollow spheres with valid resonance condition - where the constructive interference of the light waves can most probably occur - was counted, by dividing the diameter of the hollow spheres by the wavelength of the light source. After these calculations were carried out, the as-calculated data were compared to the photocatalytic activities (Fig. 37, left side) and these results are represented in Fig. 38.

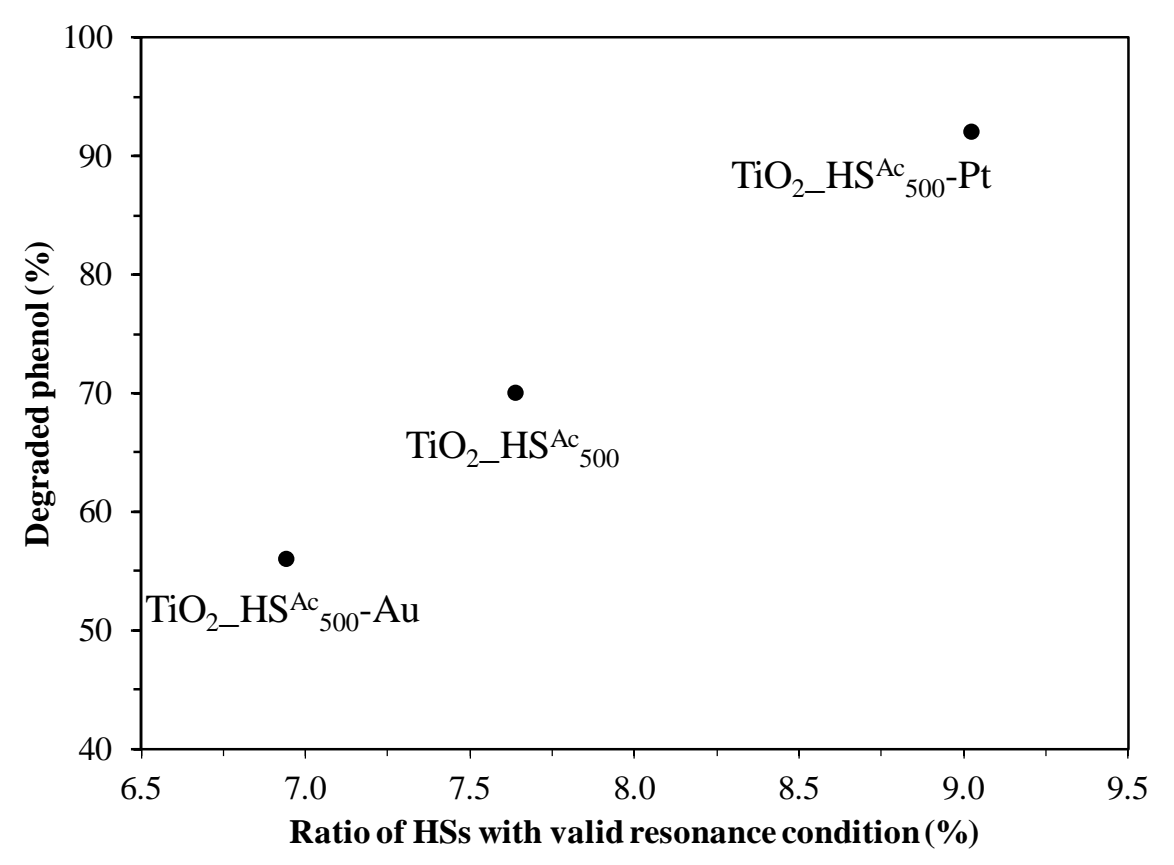

Figure 38 Comparison of the ratio of $\mathrm{TiO}_{2}$-HSs with enhanced light trapping properties to the observed amount of degraded phenol model pollutant under UV light irradiation by the end of the 240-min-long experiments.

It can be seen in the figure, that the observed photocatalytic activity $\left(\mathrm{TiO}_{2} \_\mathrm{HS}^{\mathrm{Ac}}{ }_{500}-\mathrm{Au}<\right.$ $\mathrm{TiO}_{2} \mathrm{HS}^{\mathrm{Ac}_{500}}<\mathrm{TiO}_{2} \mathrm{HS}^{\mathrm{Ac}}{ }_{500}-\mathrm{Pt}$ ) indeed corresponds well to the increasing ratio of hollow 
spheres with valid resonance condition. Since it is well-known, that the excitability of a photocatalyst correlates with the intensity of the light source, and that the intensity of a wave is proportional to the square of its amplitude, then it can be expected, that after constructive interference occurs resulting in the increase of the amplitude, the light waves with higher intensity could indeed cause the enhancement of the photocatalytic activity.

To sum up, based on the results of the photocatalytic activity experiments, it was observed that in almost every case the reference $\mathrm{TiO}_{2}$ nno_HS ${ }^{\mathrm{Ac}}$ 500 sample proved to be the least efficient and compared to that, the fabrication of hollow spherical morphology (base material $\mathrm{TiO}_{2} \mathrm{HS}^{\mathrm{Ac}}{ }_{500}$ ) indeed increased the photocatalytic activity, as did the deposition of noble metals in most cases. 


\section{Conclusions}

In the course of my research work various methods were successfully applied to increase the photocatalytic activity of $\mathrm{TiO}_{2}$-based photocatalysts. During the investigation of morpho-structural properties and photocatalytic activities significant findings were discussed about their causal relationship.

A series of nanosized rutile phase titanium dioxide was obtained by the addition of different amounts of hydrogen peroxide during the synthesis method. The optimal ratio of the added hydrogen peroxide was found to be $n_{T i}: n_{H_{2} \mathrm{O}_{2}}=1: 2$. Other ratios did not result in the appearance of peroxo groups in the series. Photocatalytic activity measurements showed that Rutile-H2 had superior photocatalytic performance for phenol degradation under visible light irradiation compared to the other $\mathrm{TiO}_{2}$-s in the series, exceeding the photocatalytic activity of reference photocatalysts (Aeroxide P25 and US-R.N. Rutile). The reason for the enhanced photocatalytic activity was deduced to be due to the resultant effect of the electron attracting inductive effect conveyed by the presence of peroxo groups and the enhanced visible light absorption. The Rutile- $\mathrm{H} 2 \mathrm{TiO}_{2}$ retained its superior photocatalytic activity even after 3 consecutive phenol degradation tests. The first order derivative of the DR spectra pointed out that the order of light absorption of the investigated self-made $\mathrm{TiO}_{2}$-s could be associated with the resulting photocatalytic performances, confirming the enhanced visible light excitability of sample Rutile-H2 caused by the peroxo groups. IR measurements did not show peroxo groups in the home-made $\mathrm{TiO}_{2}-\mathrm{s}$ presumably due to its lower limit of detection compared to XPS. XPS measurements, however, confirmed the formation of peroxo groups in our Rutile- $\mathrm{H} 2 \mathrm{TiO}_{2}$. To our best knowledge, forming peroxo groups on the surface of pure nanosized rutile have not been reported prior our work.

The effects of peroxo groups on the photocatalytic activity of amorphous and anatase phase $\mathrm{TiO}_{2}$-s were also investigated by modifying our prior synthesis method by adjusting the $\mathrm{pH}$ to 3 , which also resulted in the remarkable enhancement of optical properties. Application of $55^{\circ} \mathrm{C}$ and $70{ }^{\circ} \mathrm{C}$ as crystallization temperature resulted in either amorphous, or predominantly anatase phase peroxo $\mathrm{TiO}_{2}-\mathrm{s}$. DRS measurements pointed out that increasing the $\mathrm{pH}$ to 3 during the synthesis resulted in immensely increased visible light excitability of home-made peroxo titania, due to the appearance of localized states within the band gap, which originated presumably from the amorphous nature of the material and 
its chemical composition (sodium titanites and $\mathrm{Ti}^{3+}$ ). In the case of Amorphous- $\mathrm{H}_{2} \mathrm{TiO}_{2}$ the presence of sodium titanate was demonstrated directly by DRS (electron-transition band located in the UV region), Raman (bands at 514 and $636 \mathrm{~cm}^{-1}$ ) and XPS (Na1s binding energy at $1072 \mathrm{eV}$ ) measurements, and indirectly by its dissolution in oxalic acid. Moreover, XPS (and IR measurements in the case of Amorphous-H2 sample) confirmed the presence of peroxo groups, which together with the above-mentioned structural entities were deduced to be responsible for the greatly enhanced photocatalytic activity of sample Amorphous-H2 which exceeded the photocatalytic efficiency of all investigated $\mathrm{TiO}_{2}-\mathrm{s}$. Further XPS measurements revealed, that a certain degree of crystallinity is required to preserve the activity enhancement caused by the peroxo groups.

The synthesis method of our own Rutile-H2 $\mathrm{TiO}_{2}$ was used to coat carbon sphere templates to obtain $\mathrm{TiO}_{2}$-CS composites, then - by their subsequent calcination - $\mathrm{TiO}_{2}$ hollow structures. A $\mathrm{TiO}_{2}-\mathrm{CS}$ composite and $\mathrm{TiO}_{2}-\mathrm{HS}$ sample were compared, and it was found, that the addition of CS templates decreased the crystallinity and photocatalytic activity. Since the $\mathrm{TiO}_{2}$-HS was found to be more effective than the $\mathrm{TiO}_{2}-\mathrm{CS}$ composite system, the latter was not investigated further. A series of $\mathrm{TiO}_{2}-\mathrm{HSs}$ was synthesized by applying different synthesis conditions (different purification methods of carbon spheres, different precursor quantity and furnace). Centrifugation was found to be the most feasible CS purification method and applying muffle furnace (without additional air supply) was found to be most effective way to remove the CS templates in the case of the as-investigated samples. $\mathrm{TiO}_{2}$ sample named as $\mathrm{H} 2 \_H S \_5$ was synthesized by applying these conditions which resulted in $\mathrm{TiO}_{2}-\mathrm{HS}$ with hollow structural morphology. H2_HS_5 $\mathrm{TiO}_{2}$ possessed both the best absolute and surface normalized photocatalytic activity among the investigated $\mathrm{TiO}_{2}$-s. On one hand, this was attributed to its increased light-harvesting capabilities (due to its unique morphology), and on the other, to the lowest carbon content on its surface and the higher ratio of the polar $\mathrm{O}-\mathrm{C}=\mathrm{O}$ functional groups, which presumably facilitate the direct contact between water (the matrix of the photocatalytic process) and the surface of the photocatalyst. The stability of this $\mathrm{TiO}_{2}$ proved to be remarkable as it retained its photocatalytic activity, crystal phase composition and morphology after 3 consecutive phenol degradation measurements.

Finally, titanium dioxide hollow spheres were synthesized applying different synthesis method and parameters. The CS purification solvent (acetone or ethanol) did not influence the characteristics of the $\mathrm{TiO}_{2}-\mathrm{HSs}$, whereas applying $500{ }^{\circ} \mathrm{C}$ calcination 
temperature resulted in anatase phase $\mathrm{TiO}_{2}-\mathrm{HSs}$ with perfect, truly hollow spherical morphology, while applying $800{ }^{\circ} \mathrm{C}$ yielded rutile phase $\mathrm{TiO}_{2}-\mathrm{HSs}$ with less regular morphology. The $\mathrm{TiO}_{2}$-HS possessing the best properties in terms of morphology was selected for the deposition of gold and platinum nanoparticles in $0.25 \mathrm{wt} \%$. SEM and TEM measurements confirmed, that the morphology remained intact after the deposition process and that the noble metal nanoparticles were distributed evenly on the $\mathrm{TiO}_{2}-\mathrm{HSs}$. The photocatalytic activity enhancement caused by either the unique morphology and the presence of noble metals was investigated by the degradation of phenol and oxalic acid under both UV and visible light irradiation using the base hollow spherical, and solid (non-hollow) spherical $\mathrm{TiO}_{2}$-s as references. The hollow spherical morphology resulted in a remarkable $166 \%$ and $135 \%$ increase in photocatalytic activity during UV light irradiation compared to the non-hollow solid reference sample in the case of phenol and oxalic acid, respectively. Using the same reference, after combining the hollow spherical morphology with the deposition of noble metals in the case of the gold-deposited sample these values were $113 \%$ and $178 \%$ for phenol, along with $276 \%$ and $178 \%$ for oxalic acid in the case of platinumdeposited $\mathrm{TiO}_{2}-\mathrm{s}$, respectively, under UV light irradiation. Summarizing, in the case of visible light irradiation, the gold-deposited hollow spherical $\mathrm{TiO}_{2}$ had the best photocatalytic activity, while in the case of UV irradiation the platinum containing hollow spherical $\mathrm{TiO}_{2}$ proved to be the most efficient for the degradation of both oxalic acid and phenol. The photocatalytic activity order - observed during the decomposition of phenol under UV light irradiation - was attributed to the enhanced light trapping properties of the samples: the photocatalytic activity increased with increasing proportions of titanium dioxide hollow sphere diameters close to the integer multiple of the excitation light source's wavelength, i.e. in which case the occurrence of constructive interference was more probable. 


\section{7. Összefoglalás}

Kutatómunkám során sikeresen alkalmaztam különböző módszereket $\mathrm{TiO}_{2}$ alapú fotokatalizátorok fotokatalitikus aktivitásának megnövelésére. A fotokatalitikus aktivitások, valamint az anyagszerkezeti és felületi tulajdonságok széleskörü vizsgálata révén fontos okokozati összefüggések kerültek jellemzésre.

Nanoméretű rutil fázisú titán-dioxid sorozatot állítottam elő a szintézis során különböző mennyiségü hidrogén-peroxid alkalmazásával, melynek optimális mennyiségét $\mathrm{n}_{\mathrm{Ti}}: \mathrm{n}_{\mathrm{H}_{2} \mathrm{O}_{2}}=1: 2$-nek állapítottam meg. A többi vizsgált anyagmennyiség-arányok alkalmazása során nem alakultak ki peroxo-csoportok a $\mathrm{TiO}_{2}$-ok felszínén. A fotokatalitikus aktivitás vizsgálata során megállapítottam, hogy a Rutil- $\mathrm{H} 2 \mathrm{TiO}_{2}$ fotokatalitikus aktivitása jelentősen nagyobb volt a sorozat többi tagjához képest fenol modellszennyező és látható fénnyel történő gerjesztés esetén, amely a referenciaként használt Aeroxide P25 és US-R.N. Rutil aktivitását is meghaladta. A kiemelkedő fotokatalitikus aktivitást a peroxo-csoportok elektronvonzó induktív effektusának és a látható fény tartományába eltolódó fényelnyelés eredőjével magyaráztam. A Rutil- $\mathrm{H} 2 \mathrm{TiO}_{2}$ a kiemelkedő fotokatalitikus aktivitását 3 egymást követő fenolbontási teszt után is megőrizte. A DR spektrum első rendü deriváltjának vizsgálata során megfigyeltem, hogy a fotokatalizátorok fényelnyelésbeli sorrendje megegyezett a fotokatalitikus aktivitások sorrendjével, mely a Rutil-H2 minta esetén a peroxo-csoportok által biztosított hatékonyabb látható fénnyel való gerjeszthetőséget is alátámasztotta. Az IR mérések során a saját készítésü $\mathrm{TiO}_{2}$-ok esetén nem sikerült kimutatnom a peroxo csoportok jelenlétét, feltételezhetően az XPS módszerhez viszonyított kisebb kimutatási határ miatt. Az XPS mérések azonban igazolták a peroxocsoportok kialakulását a Rutil-H2 $\mathrm{TiO}_{2}$ esetén. Legjobb tudomásunk szerint a mi publikációnk előtt tisztán rutil fázisú nanoméretü titán-dioxidon még nem alakítottak ki peroxo-csoportokat.

A peroxo-csoportok fotokatalitikus aktivitásra gyakorolt hatását amorf és anatáz fázisú titán-dioxidok esetén is vizsgáltam. A mintákat a szintézis során 3-as pH beállítása mellett állítottam elő, mely az optikai tulajdonságok nagymértékü javulását is eredményezte. Kristályosítási hőmérsékletként 55 és $70{ }^{\circ} \mathrm{C}$-ot alkalmaztam, mely amorf, illetve túlnyomórészt anatáz fázisú peroxo-csoportokat tartalmazó TiO2-ok kialakulását eredményezte. DRS mérésekkel kimutattam, hogy a fotokatalizátorok szintézise során a pH 
3-ra történő emelésével azok gerjeszthetősége nagymértékben eltolódott a látható fény tartományába, melyet a tiltott sávon belüli lokalizált energiaállapotok megjelenésének tulajdonítottam, melyek kialakulása feltételezhetően a katalizátor amorf szerkezetével és kémiai összetételével (nátrium-titanát és $\mathrm{Ti}^{3+}$ jelenléte) hozható összefüggésbe. Az Amorf-H2 $\mathrm{TiO}_{2}$ esetén a nátrium-titanát jelenlétét közvetlenül DRS (elektronátmenethez szükséges energiák az UV régióban), Raman (514 és $636 \mathrm{~cm}^{-1}$-nél található sávok) és XPS (kötési energia 1072 eV-nál a Na1s spektrumon) mérésekkel igazoltam, illetve indirekt módon a mintának oxálsavban történő feloldásával is. Továbbá, XPS mérések segítségével sikeresen kimutattam a saját készítésű mintákban a peroxo-csoportok jelenlétét (mely a Amorf-H2 minta esetén még az IR mérések segítségével is észlelhető volt). Ezekkel a tényezőkkel (a minták sajátos kémiai összetételével és szerkezetével) magyaráztam a fotokatalizátorok jelentős aktivitásnövekedését, mely a Amorf-H2 minta esetén meghaladta az összes vizsgált $\mathrm{TiO}_{2}$ fotokatalitikus aktivitását. Továbbá, az XPS mérések eredményeinek elemzése révén megállapítottam, hogy a peroxo-csoportok-okozta aktivitásnövekedés megőrzéséhez $\mathrm{TiO}_{2}$ mintáknak bizonyos mértékü kristályossági fokkal kell rendelkezniük.

A Rutil-H2 minta szintézismódszerét felhasználva $\mathrm{TiO}_{2}$ bevonatot alakítottam ki széngömb templátok felületén $\mathrm{TiO}_{2}-\mathrm{CS}$ kompozitok előállításához, melyeknek a későbbi kalcinálásával $\mathrm{TiO}_{2}$ üreges szerkezeteket hoztam létre. A $\mathrm{TiO}_{2}-\mathrm{CS}$ kompozitok és $\mathrm{TiO}_{2}$ üreges szerkezetek összehasonlításakor megállapítottam, hogy a széngömbök jelenléte a fotokatalizátorok kristályossági fokának és fotokatalitikus aktivitásának csökkenését eredményezi. Mivel a $\mathrm{TiO}_{2}$-HS minták hatékonyabbnak bizonyultak a $\mathrm{TiO}_{2}$-CS kompozit rendszereknél, így ez utóbbiakat nem vizsgáltam tovább. Különböző szintézisparaméterek (eltérő tisztítási módszerek, prekurzor mennyiségek és kalcináló kemencék) alkalmazásával előállítottam egy sorozat $\mathrm{TiO}_{2}-\mathrm{HS}$ mintát. A széngömbök tisztításához a centrifugálás, eltávolításukhoz pedig a statikus kemencében történő kezelés (levegőbevezetés nélkül) bizonyult a leghatékonyabbnak, melyek alkalmazásával sikeresen állítottam elő üreges gömb szerkezetű $\mathrm{TiO}_{2}$-ot (H2_HS_5 elnevezésű minta). A H2_HS_5 $\mathrm{TiO}_{2}$ rendelkezett a legjobb abszolút és a legjobb felületre vonatkoztatott fotokatalitikus aktivitással a vizsgált $\mathrm{TiO}_{2}$-ok közül. A kiemelkedő fotokatalitikus aktivitást a minta (üreges morfológiájából eredő) hatékonyabb fénycsapdázásával magyaráztam, illetve azzal, hogy a felületén a sorozat többi tagjához képest a szén a legkisebb mennyiségben, a poláris $\mathrm{O}-\mathrm{C}=\mathrm{O}$ funkciós csoportok pedig a legnagyobb mennyiségben voltak jelen, melyek feltételezhetően elősegítették a fotokatalizátor felülete és a víz (a fotokatalitikus aktivitási tesztek mátrixa) 
közötti közvetlen érintkezést. A H2_HS_5 TiO2 az újrafelhasználhatósági tesztek (3 egymást követő fenolbontási kísérlet) során rendkívül stabilnak bizonyult, teljes mértékben megőrizve a fotokatalitikus aktivitását, kristályos összetételét és morfológiáját.

Végül, sikeresen állítottam elő tökéletes üreges gömb morfológiájú titán-dioxidokat egy másik (nem Rutil-H2-alapú) szintézismódszer és más paraméterek alkalmazásával. A széngömb templátok tisztításához használt oldószer (aceton vagy etanol) nem befolyásolta az előállított $\mathrm{TiO}_{2}$-HSs-ök tulajdonságait. A templátok $500{ }^{\circ} \mathrm{C}$-on történő eltávolítását követően anatáz fázisú, tökéletesen szabályos üreges gömb morfológiájú $\mathrm{TiO}_{2}$-ot kaptam, míg a $800{ }^{\circ} \mathrm{C}$-os kalcinálási hőmérsékletet alkalmazása rutil fázisú, kevésbé szabályos morfológiájú $\mathrm{TiO}_{2}$-ot eredményezett. A morfológiai szempontból legjobb tulajdonságú $\mathrm{TiO}_{2}$-ot használtam fel arany és platina nanorészecskék (0,25 tömegszázalékban történő) leválasztásához. SEM és TEM mérésekkel igazoltam, hogy a morfológia a nemesfémleválasztást követően is változatlan maradt, továbbá, a nemesfém nanorészecskék egyenletesen oszlottak el a $\mathrm{TiO}_{2}$-HS-ök felületén. Az üreges gömb morfológia, és a nemesfémek jelenlétéből adódó fotokatalitikus aktivitásnövekedést fenol és oxálsav modellszennyezők bontásával vizsgáltam UV és látható fénnyel történő gerjesztés esetén egyaránt, nemesfémet nem tartalmazó üreges, és tömör gömb morfológiájú referencia $\mathrm{TiO}_{2}-$ ok felhasználásával. Az üreges gömb morfológia 166 és 135\%-os aktivitásnövekedést eredményezett fenol és oxálsav esetén a tömör gömb morfológiájú referenciához képest UV fénnyel történő gerjesztés esetén. Ugyanezen referencia fotokatalitikus aktivitásához hasonlítva az üreges gömb morfológiájú nemesfémleválasztással előállított kompozitok aktivitását az értékek az arannyal módosított minta esetén 113 és 178\%-nak adódtak fenol és oxálsav modellszennyezők esetén, illetve 276 és 178\%-nak a platinával módosított mintáknál UV fénnyel történő gerjesztés során. Látható fénnyel történő gerjesztés esetén az arannyal módosított minta bizonyult a legjobbnak, míg UV-val történő gerjesztéskor a platinával módosított üreges $\mathrm{TiO}_{2}$ mutatta a legnagyobb fotokatalitikus aktivitást mind fenol, mind oxálsav esetén. A fenol UV fénnyel történő bontása során tapasztalt fotokatalitikus aktivitásbeli sorrendet a minták hatékonyabb fénycsapdázó tulajdonságával hoztam összefüggésbe: a fotokatalitikus aktivitás abban a sorrendben növekedett, ahogy a minták gömbátmérőinek nagyobb hányada esett a gerjesztő fény hullámhosszának egész számú többszörösének közelébe, vagyis ahol a konstruktív interferencia fellépése nagyobb mértékben volt feltételezhető. 


\section{References}

[1] A. Fujishima, K. Honda, Nature 238 (1972) 37-38.

[2] M. Pelaez, N.T. Nolan, S.C. Pillai, M.K. Seery, P. Falaras, A.G. Kontos, P.S.M.

Dunlop, J.W.J. Hamilton, J.A. Byrne, K. O'Shea, M.H. Entezari, D.D. Dionysiou, Appl. Catal. B Environ. 125 (2012) 331-349.

[3] D. Flak, A. Braun, B.S. Mun, J.B. Park, M. Parlinska-Wojtan, T. Graule, M. Rekas, Phys. Chem. Chem. Phys. 15 (2013) 1417-1430.

[4] M.K. Ram, O. Yavuz, V. Lahsangah, M. Aldissi, Sens. Actuators B Chem. 106 (2005) 750-757.

[5] K. Zakrzewska, M. Radecka, Thin Solid Films 515 (2007) 8332-8338.

[6] D.R. Miller, S.A. Akbar, P.A. Morris, Sens. Actuators B Chem. 204 (2014) 250-272.

[7] U. Lange, T. Hirsch, V.M. Mirsky, O.S. Wolfbeis, Electrochim. Acta 56 (2011) 37073712.

[8] M. Krichevskaya, S. Preis, A. Moiseev, N. Pronina, J. Deubener, Catal. Today 280 (2017) 93-98.

[9] P. Pichat, J. Disdier, C. Hoang-Van, D. Mas, G. Goutailler, C. Gaysse, Catal. Today 63 (2000) 363-369.

[10] X.Z. Li, M.F. Hou, F.B. Li, H. Chua, Ind. Eng. Chem. Res. 45 (2006) 487-494.

[11] S. Banerjee, D.D. Dionysiou, S.C. Pillai, Appl. Catal. B Environ. 176-177 (2015) 396428.

[12] M. Miyauchi, Phys. Chem. Chem. Phys. 10 (2008) 6258-6265.

[13] A. Fujishima, T.N. Rao, D.A. Tryk, J. Photochem. Photobiol. C 1 (2000) 1-21.

[14] D.M. Giolando, Sol. Energy 124 (2016) 76-81.

[15] K.T. Meilert, D. Laub, J. Kiwi, J. Mol. Catal. A: Chem. 237 (2005) 101-108.

[16] G. Vereb, P. Kassai, E. Nascimben Santos, G. Arthanareeswaran, C. Hodur, Z. Laszlo, Environ. Sci. Pollut. Res. Int. (2020).

[17] G. Veréb, V. Kálmán, T. Gyulavári, S. Kertész, S. Beszédes, G. Kovács, K. Hernádi, Z. Pap, C. Hodúr, Z. László, Water Supply 19 (2019) 1167-1174.

[18] C. Han, J. Lalley, D. Namboodiri, K. Cromer, M.N. Nadagouda, Curr. Opin. Chem.

Eng. 11 (2016) 46-51.

[19] V. Scuderi, M.A. Buccheri, G. Impellizzeri, A. Di Mauro, G. Rappazzo, K. Bergum, B.G. Svensson, V. Privitera, Mater. Sci. Semicond. Process. 42 (2016) 32-35.

[20] M. Madian, A. Eychmüller, L. Giebeler, Batteries 4 (2018) 7.

[21] Y. Bao, Q.L. Kang, C. Liu, J.Z. Ma, Mater. Lett. 214 (2018) 272-275.

[22] B.Y. Guan, L. Yu, J. Li, X.W. Lou, Sci. Adv. 2 (2016) e1501554.

[23] S. Shi, Y. Chen, J. Lee, Z. Jiang, X. Cui, J. Solid State Electrochem. 22 (2017) 705715.

[24] V. Augugliaro, T. Caronna, A. Di Paola, G. Marcì, M. Pagliaro, G. Palmisano, L. Palmisano, (2010) 623-645.

[25] D.M. Blake, P.-C. Maness, Z. Huang, E.J. Wolfrum, J. Huang, W.A. Jacoby, Sep. Purif. Methods 28 (2008) 1-50.

[26] R. Cai, H. Sakai, K. Hashimoto, Y. Kubota, A. Fujishima, Denki Kagaku oyobi Kogyo Butsuri Kagaku 60 (1992) 314-321.

[27] Z. Li, L. Yu, Materials 12 (2019).

[28] M. Gratzel, Inorg. Chem. 44 (2005) 6841-6851.

[29] C. Clavero, Nat. Photonics 8 (2014) 95-103. 
[30] C. Janáky, D. Hursán, B. Endrődi, W. Chanmanee, D. Roy, D. Liu, N.R. de Tacconi, B.H. Dennis, K. Rajeshwar, ACS Energy Lett. 1 (2016) 332-338.

[31] B. Endrodi, E. Kecsenovity, A. Samu, F. Darvas, R.V. Jones, V. Torok, A. Danyi, C. Janaky, ACS Energy Lett. 4 (2019) 1770-1777.

[32] G.N. Nomikos, P. Panagiotopoulou, D.I. Kondarides, X.E. Verykios, Appl. Catal. B Environ. 146 (2014) 249-257.

[33] A. Samokhvalov, Renew. Sust. Energ. Rev. 72 (2017) 981-1000.

[34] Y. AlSalka, A. Hakki, M. Fleisch, D.W. Bahnemann, J. Photochem. Photobiol. A Chem. 366 (2018) 81-90.

[35] L.J. Fang, X.L. Wang, Y.H. Li, P.F. Liu, Y.L. Wang, H.D. Zeng, H.G. Yang, Appl. Catal. B Environ. 200 (2017) 578-584.

[36] D. Chen, L. Zou, S. Li, F. Zheng, Sci. Rep. 6 (2016) 20335.

[37] Z. Li, C. Kong, G. Lu, Int. J. Hydrog. Energy 40 (2015) 9061-9068.

[38] Z. Yan, H. Wu, A. Han, X. Yu, P. Du, Int. J. Hydrog. Energy 39 (2014) 13353-13360.

[39] M. Wang, J. Chen, X. Liao, Z. Liu, J. Zhang, L. Gao, Y. Li, Int. J. Hydrog. Energy 39 (2014) 14581-14587.

[40] Z. Pap, Z.R. Toth, V. Danciu, L. Baia, G. Kovacs, Materials 8 (2014) 162-180.

[41] S.K. Parayil, H.S. Kibombo, C.-M. Wu, R. Peng, J. Baltrusaitis, R.T. Koodali, Int. J. Hydrog. Energy 37 (2012) 8257-8267.

[42] C.-H. Liao, C.-W. Huang, J.C.S. Wu, Catalysts 2 (2012) 490-516.

[43] M.C. Wu, J. Hiltunen, A. Sapi, A. Avila, W. Larsson, H.C. Liao, M. Huuhtanen, G.

Toth, A. Shchukarev, N. Laufer, A. Kukovecz, Z. Konya, J.P. Mikkola, R. Keiski, W.F.

Su, Y.F. Chen, H. Jantunen, P.M. Ajayan, R. Vajtai, K. Kordas, ACS Nano 5 (2011) 50255030 .

[44] C.u. Gomes Silva, R. Juárez, T. Marino, R. Molinari, H. García, J. Am. Chem. Soc. 133 (2011) 595-602.

[45] N. Biswal, D.P. Das, S. Martha, K.M. Parida, Int. J. Hydrog. Energy 36 (2011) 1345213460.

[46] X. Chen, S. Shen, L. Guo, S.S. Mao, Chem. Rev. 110 (2010) 6503-6570.

[47] A. Fihri, V. Artero, A. Pereira, M. Fontecave, Dalton Trans. (2008) 5567-5569.

[48] A. Patsoura, D.I. Kondarides, X.E. Verykios, Catal. Today 124 (2007) 94-102.

[49] J. Zhang, Z. Zhu, Y. Tang, K. Mullen, X. Feng, Adv. Mater. 26 (2014) 734-738.

[50] S.N. Frank, A.J. Bard, J. Am. Chem. Soc. 99 (1977) 303-304.

[51] A. Picado, S.M. Paixão, L. Moita, L. Silva, M.S. Diniz, J. Lourenço, I. Peres, L.

Castro, J.B. Correia, J. Pereira, I. Ferreira, A.P.A. Matos, P. Barquinha, E. Mendonca,

Front. Env. Sci. Eng. 9 (2015) 793-803.

[52] A. El Goresy, L. Dubrovinsky, P. Gillet, G. Graup, M. Chen, Am. Mineral. 95 (2010) 892-895.

[53] A. Di Paola, M. Bellardita, L. Palmisano, Catalysts 3 (2013) 36-73.

[54] Y. Hu, H.L. Tsai, C.L. Huang, J. Eur. Ceram. Soc. 23 (2003) 691-696.

[55] S. Banerjee, J. Gopal, P. Muraleedharan, A.K. Tyagi, B. Rai, Curr. Sci. 90 (2006) 1378-1383.

[56] M.A. Fox, M.T. Dulay, Chem. Rev. 93 (1993) 341-357.

[57] H.P. Boehm, Discuss. Faraday Soc. 52 (1971) 264.

[58] K.-J. Kim, K.D. Benkstein, J. van de Lagemaat, A.J. Frank, Chem. Mater. 14 (2002) 1042-1047.

[59] J. Colina-Marquez, F. Machuca-Martinez, G. Li Puma, Molecules 20 (2015) 1335413373. 
[60] S. Sakthivel, B. Neppolian, M.V. Shankar, B. Arabindoo, M. Palanichamy, V. Murugesan, Sol. Energy Mater. Sol. Cells 77 (2003) 65-82.

[61] S. Ahmed, M.G. Rasul, R. Brown, M.A. Hashib, J. Environ. Manage. 92 (2011) 311330.

[62] S. Ahmed, M.G. Rasul, W.N. Martens, R. Brown, M.A. Hashib, Desalination 261 (2010) 3-18.

[63] J. Chen, F. Qiu, W. Xu, S. Cao, H. Zhu, Appl. Catal. A Gen. 495 (2015) 131-140.

[64] J.-M. Herrmann, J. Matos, J. Disdier, C. Guillard, J. Laine, S. Malato, J. Blanco, Catal. Today 54 (1999) 255-265.

[65] M.G. Antoniou, D.D. Dionysiou, Catal. Today 124 (2007) 215-223.

[66] R. Kun, S. Tarján, A. Oszkó, T. Seemann, V. Zöllmer, M. Busse, I. Dékány, J. Solid State Chem. 182 (2009) 3076-3084.

[67] G. Veréb, L. Manczinger, A. Oszkó, A. Sienkiewicz, L. Forró, K. Mogyorósi, A. Dombi, K. Hernádi, Appl. Catal. B Environ. 129 (2013) 194-201.

[68] G. Veréb, L. Manczinger, G. Bozsó, A. Sienkiewicz, L. Forró, K. Mogyorósi, K. Hernádi, A. Dombi, Appl. Catal. B Environ. 129 (2013) 566-574.

[69] G. Veréb, Z. Ambrus, Z. Pap, Á. Kmetykó, A. Dombi, V. Danciu, A. Cheesman, K. Mogyorósi, Appl. Catal. A Gen. 417-418 (2012) 26-36.

[70] N. Balázs, K. Mogyorósi, D.F. Srankó, A. Pallagi, T. Alapi, A. Oszkó, A. Dombi, P. Sipos, Appl. Catal. B Environ. 84 (2008) 356-362.

[71] Z. Wang, W. Cai, X. Hong, X. Zhao, F. Xu, C. Cai, Appl. Catal. B Environ. 57 (2005) 223-231.

[72] L.G. Devi, B.G. Anitha, Surf. Interfaces 11 (2018) 48-56.

[73] B. Réti, G.I. Kiss, T. Gyulavári, K. Baan, K. Magyari, K. Hernadi, Catal. Today 284 (2017) 160-168.

[74] A.K. Aboul-Gheit, S.M. Abdel-Hamid, S.A. Mahmoud, R.A. El-Salamony, J. Valyon, M.R. Mihályi, Á. Szegedi, J. Mater. Sci. 46 (2011) 3319-3329.

[75] M. Qamar, B. Merzougui, D. Anjum, A.S. Hakeem, Z.H. Yamani, D. Bahnemann, Catal. Today 230 (2014) 158-165.

[76] R. Atchudan, T.N. Jebakumar Immanuel Edison, S. Perumal, D. Karthikeyan, Y.R. Lee, J. Photochem. Photobiol. A Chem. 333 (2017) 92-104.

[77] M.K. Sahu, R.K. Patel, J. Ind. Eng. Chem. 40 (2016) 72-82.

[78] R.M. Mohamed, D. McKinney, M.W. Kadi, I.A. Mkhalid, W. Sigmund, Ceram. Int. 42 (2016) 9375-9381.

[79] B. Wawrzyniak, A. Morawski, Appl. Catal. B Environ. 62 (2006) 150-158.

[80] Z. Kása, K. Saszet, A. Dombi, K. Hernádi, L. Baia, K. Magyari, Z. Pap, Mater. Sci. Semicond. Process. 74 (2018) 21-30.

[81] A. Houas, Appl. Catal. B Environ. 31 (2001) 145-157.

[82] W. Raza, M.M. Haque, M. Muneer, D. Bahnemann, Arab. J. Chem. (2015).

[83] W. Bahnemann, M. Muneer, M.M. Haque, Catal. Today 124 (2007) 133-148.

[84] K. Kovacs, J. Farkas, G. Vereb, E. Arany, G. Simon, K. Schrantz, A. Dombi, K. Hernadi, T. Alapi, J Environ Sci Health B 51 (2016) 205-214.

[85] K. Kovacs, J. Farkas, G. Vereb, E. Arany, G. Simon, K. Schrantz, A. Dombi, K. Hernadi, T. Alapi, J. Environ. Sci. Health B 51 (2016) 205-214.

[86] G. Rózsa, Z. Kozmér, T. Alapi, K. Schrantz, E. Takács, L. Wojnárovits, Catal. Today 284 (2017) 187-194.

[87] P. Anil Kumar Reddy, P. Venkata Laxma Reddy, V. Maitrey Sharma, B. Srinivas, V.D. Kumari, M. Subrahmanyam, J. Water Resource Prot. 02 (2010) 235-244.

[88] M. Gar Alalm, A. Tawfik, S. Ookawara, J. Environ. Chem. Eng. 4 (2016) 1929-1937. 
[89] W. Lin, H. Zheng, P. Zhang, T. Xu, Appl. Catal. A Gen. 521 (2016) 75-82.

[90] A. Bonnefond, E. Gonzalez, J.M. Asua, J.R. Leiza, J. Kiwi, C. Pulgarin, S. Rtimi, Colloids Surf. B Biointerfaces 135 (2015) 1-7.

[91] S. Malato, M.I. Maldonado, P. Fernández-Ibáñez, I. Oller, I. Polo, R. SánchezMoreno, Mater. Sci. Semicond. Process. 42 (2016) 15-23.

[92] S. Malato, P. Fernández-Ibáñez, M.I. Maldonado, J. Blanco, W. Gernjak, Catal. Today 147 (2009) 1-59.

[93] C. Karunakaran, A. Vijayabalan, G. Manikandan, P. Gomathisankar, Catal. Commun. 12 (2011) 826-829.

[94] C. Pablos, J. Marugan, R. van Grieken, P.S.M. Dunlop, J.W.J. Hamilton, D.D. Dionysiou, J.A. Byrne, Molecules 22 (2017).

[95] N.F.F. Moreira, C. Narciso-da-Rocha, M.I. Polo-Lopez, L.M. Pastrana-Martinez, J.L. Faria, C.M. Manaia, P. Fernandez-Ibanez, O.C. Nunes, A.M.T. Silva, Water Res. 135 (2018) 195-206.

[96] Y. Ohko, I. Ando, C. Niwa, T. Tatsuma, T. Yamamura, T. Nakashima, Y. Kubota, A. Fujishima, Environ. Sci. Technol. 35 (2001) 2365-2368.

[97] G. Vardar, T.K. Wood, Appl. Environ. Microbiol. 70 (2004) 3253-3262.

[98] E. Grabowska, J. Reszczynska, A. Zaleska, Water Res. 46 (2012) 5453-5471.

[99] T. Gyulavari, G. Vereb, Z. Pap, B. Reti, K. Baan, M. Todea, K. Magyari, I.M.

Szilagyi, K. Hernadi, Materials 12 (2019).

[100] G. Veréb: Decontamination of environmental pollutants by UV- and visible lightactive titanium dioxide-based photocatalysts, Ph.D. Thesis, University of Szeged, Szeged, Hungary, 2014

[101] É. Karácsonyi, L. Baia, A. Dombi, V. Danciu, K. Mogyorósi, L.C. Pop, G. Kovács, V. Coşoveanu, A. Vulpoi, S. Simon, Z. Pap, Catal. Today 208 (2013) 19-27.

[102] N. Quici, M.E. Morgada, G. Piperata, P. Babay, R.T. Gettar, M.I. Litter, Catal.

Today 101 (2005) 253-260.

[103] C. Martínez, M. Canle L, M.I. Fernández, J.A. Santaballa, J. Faria, Appl. Catal. B Environ. 107 (2011) 110-118.

[104] L. Yang, L.E. Yu, M.B. Ray, Water Res. 42 (2008) 3480-3488.

[105] T. Matsunaga, R. Tomoda, T. Nakajima, H. Wake, FEMS Microbiol. Lett. 29 (1985) 211-214.

[106] W.A. Jacoby, P.C. Maness, E.J. Wolfrum, D.M. Blake, J.A. Fennell, Environ. Sci. Technol. 32 (1998) 2650-2653.

[107] M. Iwase, K. Yamada, T. Kurisaki, O.O. Prieto-Mahaney, B. Ohtani, H. Wakita, Appl. Catal. B Environ. 132-133 (2013) 39-44.

[108] D.M. Schultz, T.P. Yoon, Science 343 (2014) 1239176.

[109] M.P. Thekaekara, Sol. Energy 18 (1976) 309-325.

[110] A. Vidal, A.I. Díaz, A. El Hraiki, M. Romero, I. Muguruza, F. Senhaji, J. González, Catal. Today 54 (1999) 283-290.

[111] Y. Sang, H. Liu, A. Umar, ChemCatChem 7 (2015) 559-573.

[112] M.R.D. Khaki, M.S. Shafeeyan, A.A.A. Raman, W. Daud, J. Environ. Manage. 198 (2017) 78-94.

[113] F. Huang, A. Yan, H. Zhao, Semicond. Photocatal. Mater. Mech. Appl. (2016) 3180.

[114] H. Lin, L. Li, M. Zhao, X. Huang, X. Chen, G. Li, R. Yu, J. Am. Chem. Soc. 134 (2012) 8328-8331.

[115] H. Yin, X. Wang, L. Wang, Q. N, H. Zhao, J. Alloys Compd. 640 (2015) 68-74.

[116] R. Ren, Z. Wen, S. Cui, Y. Hou, X. Guo, J. Chen, Sci. Rep. 5 (2015) 10714. 
[117] Z. Pap, K. Mogyorósi, G. Veréb, A. Dombi, K. Hernádi, V. Danciu, L. Baia, J. Mol. Struct. 1073 (2014) 157-163.

[118] G. Liu, X. Wang, Z. Chen, H.M. Cheng, G.Q. Lu, J. Colloid Interface Sci. 329 (2009) 331-338.

[119] R. Alexandrescu, M. Scarisoreanu, I. Morjan, R. Birjega, C. Fleaca, C. Luculescu, I. Soare, O. Cretu, C.C. Negrila, N. Lazarescu, V. Ciupina, Appl. Surf. Sci. 255 (2009) 53735377.

[120] P.N. Gaikwad, P.P. Hankare, T.M. Wandre, K.M. Garadkar, R. Sasikala, Mater. Sci. Eng. B 205 (2016) 40-45.

[121] K. Nishijima, B. Ohtani, X. Yan, T.-a. Kamai, T. Chiyoya, T. Tsubota, N.

Murakami, T. Ohno, Chem. Phys. 339 (2007) 64-72.

[122] S.C. Padmanabhan, S.C. Pillai, J. Colreavy, S. Balakrishnan, D.E. McCormack, T.S. Perova, S.J. Hinder, J.M. Kelly, Chem. Mater. 19 (2007) 4474-4481.

[123] S. Sakthivel, H. Kisch, Angew. Chem. Int. Ed. Engl. 42 (2003) 4908-4911.

[124] Y. Zou, J.-W. Shi, D. Ma, Z. Fan, L. Lu, C. Niu, Chem. Eng. J. 322 (2017) 435-444.

[125] C. Han, J. Andersen, V. Likodimos, P. Falaras, J. Linkugel, D.D. Dionysiou, Catal.

Today 224 (2014) 132-139.

[126] B. Moongraksathum, Y.-W. Chen, Catal. Today (2017).

[127] K. Mogyorósi, Á. Kmetykó, N. Czirbus, G. Veréb, P. Sipos, A. Dombi, React. Kinet. Catal. Lett. 98 (2009) 215-225.

[128] V. Etacheri, M.K. Seery, S.J. Hinder, S.C. Pillai, Adv. Funct. Mater. 21 (2011) 37443752.

[129] M.V. Shankar, T. Kako, D. Wang, J. Ye, J. Colloid Interface Sci. 331 (2009) 132137.

[130] J. Zou, J. Gao, F. Xie, J. Alloys Compd. 497 (2010) 420-427.

[131] Y.K. Takahara, Y. Hanada, T. Ohno, S. Ushiroda, S. Ikeda, M. Matsumura, J. Appl. Electrochem. 35 (2005) 793-797.

[132] X. Li, C. Chen, J. Zhao, Langmuir 17 (2001) 4118-4122.

[133] E.V. Savinkina, L.N. Obolenskaya, G.M. Kuzmicheva, E.N. Kabachkov, A.A.

Gainanova, Y.V. Zubavichus, V.Y. Murzin, N.V. Sadovskaya, CrystEngComm 17 (2015)

7113-7123.

[134] E. Savinkina, L. Obolenskaya, G. Kuzmicheva, Appl. Nanosci. 5 (2014) 125-133.

[135] L.-L. Tan, W.-J. Ong, S.-P. Chai, A.R. Mohamed, Chem. Eng. J. 283 (2016) 12541263.

[136] J. Šubrt, P. Pulišová, J. Boháček, P. Bezdička, E. Pližingrová, L. Volfová, J. Kupčík, Mater. Res. Bull. 49 (2014) 405-412.

[137] J. Mühlebach, K. Müller, G. Schwarzenbach, Inorg. Chem. 9 (1970) 2381-2390.

[138] R. Cai, K. Itoh, C. Sun, MRS Proceedings 900 (2011).

[139] S. Tanaka, D. Nogami, N. Tsuda, Y. Miyake, J. Colloid Interface Sci. 334 (2009) 188-194.

[140] M.H. Bartl, S.W. Boettcher, K.L. Frindell, G.D. Stucky, Acc. Chem. Res. 38 (2005) 263-271.

[141] B. László, K. Baán, E. Varga, A. Oszkó, A. Erdőhelyi, Z. Kónya, J. Kiss, Appl.

Catal. B Environ. 199 (2016) 473-484.

[142] Y.C. Nah, I. Paramasivam, P. Schmuki, Chemphyschem 11 (2010) 2698-2713.

[143] L. Xiang, X. Zhao, Nanomater. 7 (2017).

[144] B. Yuan, Y. Wang, H. Bian, T. Shen, Y. Wu, Z. Chen, Appl. Surf. Sci. 280 (2013)

523-529. 
[145] Y. Kondo, H. Yoshikawa, K. Awaga, M. Murayama, T. Mori, K. Sunada, S. Bandow, S. Iijima, Langmuir 24 (2008) 547-550.

[146] H. Li, Z. Bian, J. Zhu, D. Zhang, G. Li, Y. Huo, H. Li, Y. Lu, J. Am. Chem. Soc. 129 (2007) 8406-8407.

[147] K. Nakata, A. Fujishima, J. Photochem. Photobiol. C 13 (2012) 169-189.

[148] S. Eiden-Assmann, J. Widoniak, G. Maret, Chem. Mater. 16 (2004) 6-11.

[149] V. Likodimos, T. Stergiopoulos, P. Falaras, J. Kunze, P. Schmuki, J. Phys. Chem. C 112 (2008) 12687-12696.

[150] A. Kumar, R. Jose, K. Fujihara, J. Wang, S. Ramakrishna, Chem. Mater. 19 (2007) 6536-6542.

[151] Y. Li, J. Gong, G. He, Y. Deng, Mater. Chem. Phys. 129 (2011) 477-482.

[152] L.P. Bakos, N. Justh, K. Hernádi, G. Kiss, B. Réti, Z. Erdélyi, B. Parditka, I.M.

Szilágyi, J. Phys. Conf. Ser. 764 (2016) 012005.

[153] N. Justh, L.P. Bakos, K. Hernadi, G. Kiss, B. Reti, Z. Erdelyi, B. Parditka, I.M.

Szilagyi, Sci. Rep. 7 (2017) 4337.

[154] Y. Bao, Q.L. Kang, J.Z. Ma, C. Liu, Ceram. Int. 43 (2017) 8596-8602.

[155] Y. Ao, J. Xu, D. Fu, C. Yuan, Catal. Commun. 9 (2008) 2574-2577.

[156] M. Zheng, J. Cao, X. Chang, J. Wang, J. Liu, X. Ma, Mater. Lett. 60 (2006) 29912993.

[157] A.A. Deshmukh, S.D. Mhlanga, N.J. Coville, Mater. Sci. Eng. R Rep. 70 (2010) 128.

[158] M.M. Titirici, M. Antonietti, N. Baccile, Green Chem. 10 (2008) 1204-1212.

[159] M.M. Solar Energy Materials and Solar CellsTitirici, M. Antonietti, Chem. Soc. Rev. 39 (2010) 103-116.

[160] K. Lv, J. Li, X. Qing, W. Li, Q. Chen, J. Hazard. Mater. 189 (2011) 329-335.

[161] C.-C. Nguyen, N.-N. Vu, T.-O. Do, J. Mater. Chem. A 4 (2016) 4413-4419.

[162] Z.-R. Tóth, G. Kovács, K. Hernádi, L. Baia, Z. Pap, Sep. Purif. Technol. 183 (2017) 216-225.

[163] S. Fodor, G. Kovács, K. Hernádi, V. Danciu, L. Baia, Z. Pap, Catal. Today 284 (2017) 137-145.

[164] G. Kovács, S. Fodor, A. Vulpoi, K. Schrantz, A. Dombi, K. Hernádi, V. Danciu, Z. Pap, L. Baia, J. Catal. 325 (2015) 156-167.

[165] E. Grabowska, M. Marchelek, T. Klimczuk, G. Trykowski, A. Zaleska-Medynska, J. Mol. Catal. A: Chem. 423 (2016) 191-206.

[166] Á. Kmetykó, Á. Szániel, C. Tsakiroglou, A. Dombi, K. Hernádi, React. Kinet. Mech. Catal. 117 (2015) 379-390.

[167] G.L. Chiarello, E. Selli, L. Forni, Appl. Catal. B Environ. 84 (2008) 332-339.

[168] Á. Veres, J. Ménesi, Á. Juhász, O. Berkesi, N. Ábrahám, G. Bohus, A. Oszkó, G.

Pótári, N. Buzás, L. Janovák, I. Dékány, Colloid. Polym. Sci. 292 (2013) 207-217.

[169] S. Semlali, T. Pigot, D. Flahaut, J. Allouche, S. Lacombe, L. Nicole, Appl. Catal. B Environ. 150-151 (2014) 656-662.

[170] R.K. Mandal, S. Kundu, S. Sain, S.K. Pradhan, New J. Chem. 43 (2019) 2804-2816.

[171] E. Bárdos, G. Kovács, T. Gyulavári, K. Németh, E. Kecsenovity, P. Berki, L. Baia,

Z. Pap, K. Hernádi, Catal. Today 300 (2018) 28-38.

[172] Y. Lu, L. Hao, K. Matsuzaka, H. Yoshida, H. Asanuma, J. Chen, F. Pan, Mater. Sci. Semicond. Process. 24 (2014) 138-145.

[173] G. Kovács, L. Baia, A. Vulpoi, T. Radu, É. Karácsonyi, A. Dombi, K. Hernádi, V.

Danciu, S. Simon, Z. Pap, Appl. Catal. B Environ. 147 (2014) 508-517. 
[174] L. Baia, A. Vulpoi, T. Radu, É. Karácsonyi, A. Dombi, K. Hernádi, V. Danciu, S. Simon, K. Norén, S.E. Canton, G. Kovács, Z. Pap, Appl. Catal. B Environ. 148-149 (2014) 589-600.

[175] A. Kafizas, S. Kellici, J.A. Darr, I.P. Parkin, J. Photochem. Photobiol. A Chem. 204 (2009) 183-190.

[176] A.M. Kamil, H.T. Mohammed, A.A. Balakit, F.H. Hussein, D.W. Bahnemann, G.A. El-Hiti, Arab. J. Sci. Eng. 43 (2017) 199-210.

[177] P. Daram, C. Banjongprasert, W. Thongsuwan, S. Jiansirisomboon, Surf. Coat. Tech. 306 (2016) 290-294.

[178] B. Réti, K. Mogyorósi, A. Dombi, K. Hernádi, Appl. Catal. A Gen. 469 (2014) 153158.

[179] K. Majrik, A. Turcsanyi, Z. Paszti, T. Szabo, A. Domjan, J. Mihaly, A. Tompos, I. Dekany, E. Talas, Top. Catal. 61 (2018) 1323-1334.

[180] J. Matos, S. Miralles-Cuevas, A. Ruíz-Delgado, I. Oller, S. Malato, Carbon 122 (2017) 361-373.

[181] A. Janković, S. Eraković, M. Vukašinović-Sekulić, V. Mišković-Stanković, S.J.

Park, K.Y. Rhee, Prog. Org. Coat. 83 (2015) 1-10.

[182] G. Veréb, T. Gyulavári, Z. Pap, L. Baia, K. Mogyorósi, A. Dombi, K. Hernádi, RSC Adv. 5 (2015) 66636-66643.

[183] Z.L. Tang, J.Y. Zhang, Z. Cheng, Z.T. Zhang, Mater. Chem. Phys. 77 (2003) 314317.

[184] H. Zhang, J.F. Banfield, J. Phys. Chem. B 104 (2000) 3481-3487.

[185] E.P. Cox, J. Paleontol. 1 (1927) 179-183.

[186] T. Gyulavári, Z. Pap, G. Kovács, L. Baia, M. Todea, K. Hernádi, G. Veréb, Catal. Today 284 (2017) 129-136.

[187] J. Orlikowski, B. Tryba, J. Ziebro, A.W. Morawski, J. Przepiórski, Catal. Commun. 24 (2012) 5-10.

[188] X. Ye, C. Zheng, L. Ma, X. Huang, Mater. Sci. Semicond. Process. 31 (2015) 295301.

[189] C.G. Silva, J.L. Faria, Photochemical \& photobiological sciences : Official journal of the European Photochemistry Association and the European Society for Photobiology 8 (2009) 705-711.

[190] M.R. Ayers, A.J. Hunt, Mater. Lett. 34 (1998) 290-293.

[191] D. Robert, S. Parra, C. Pulgarin, A. Krzton, J.V. Weber, Appl. Surf. Sci. 167 (2000) 51-58.

[192] K.E. Rajashekhar, L.G. Devi, J. Mol. Catal. A: Chem. 374-375 (2013) 12-21.

[193] Z. Pap, L. Baia, K. Mogyorósi, A. Dombi, A. Oszkó, V. Danciu, Catal. Commun. 17 (2012) 1-7.

[194] Z. Pap, V. Danciu, Z. Cegléd, Á. Kukovecz, A. Oszkó, A. Dombi, K. Mogyorósi, Appl. Catal. B Environ. 101 (2011) 461-470.

[195] C.D. Wagner, D.A. Zatko, R.H. Raymond, Anal. Chem. 52 (1980) 1445-1451.

[196] Z. Pap, É. Karácsonyi, Z. Cegléd, A. Dombi, V. Danciu, I.C. Popescu, L. Baia, A.

Oszkó, K. Mogyorósi, Appl. Catal. B Environ. 111-112 (2012) 595-604.

[197] D. Foix, M. Sathiya, E. McCalla, J.-M. Tarascon, D. Gonbeau, J. Phys. Chem. C 120 (2016) 862-874.

[198] L.-B. Xiong, J.-L. Li, B. Yang, Y. Yu, J. Nanomater. 2012 (2012) 1-13.

[199] S. Rtimi, J. Nesic, C. Pulgarin, R. Sanjines, M. Bensimon, J. Kiwi, Interface Focus 5 (2015) 20140046. 
[200] T. Gyulavári, G. Veréb, Z. Pap, A. Dombi, K. Hernádi, Catal. Today 313 (2018) 231-238.

[201] S. Yin, H. Hasegawa, D. Maeda, M. Ishitsuka, T. Sato, J. Photochem. Photobiol. A Chem. 163 (2004) 1-8.

[202] J. Noh, M. Yi, S. Hwang, K.M. Im, T. Yu, J. Kim, J. Ind. Eng. Chem. 33 (2016) 369373.

[203] P. Kubelka, F. Munk, Z. Tech. Phys. 12 (1931) 593-601.

[204] Q. Guo, Z. Zhang, X. Ma, K. Jing, M. Shen, N. Yu, J. Tang, D.D. Dionysiou, Sep.

Purif. Technol. 175 (2017) 305-313.

[205] P. Tengvall, L. Bertilsson, B. Liedberg, H. Elwing, I. Lundström, J. Colloid Interface Sci. 139 (1990) 575-580.

[206] T. Busani, R.A.B. Devine, Semicond. Sci. Technol. 20 (2005) 870-875.

[207] G.V. Jere, C.C. Patel, Can. J. Chem. 40 (1962) 1576-1578.

[208] T. Ohsaka, J. Phys. Soc. Jpn. 48 (1980) 1661-1668.

[209] R.A. Zárate, S. Fuentes, J.P. Wiff, V.M. Fuenzalida, A.L. Cabrera, J. Phys. Chem.

Solids 68 (2007) 628-637.

[210] W.-D. Yang, C.T. Nam, J.-C. Chung, H.-Y. Huang, J. Nanomater. 2016 (2016) 1-9.

[211] M.E. Pilleux, C.R. Grahmann, V.M. Fuenzalida, J. Am. Ceram. Soc. 77 (1994) 16011604.

[212] C.M. Rodrigues, O.P. Ferreira, O.L. Alves, J. Braz. Chem. Soc. 21 (2010) 13411348.

[213] A.G. Agrios, K.A. Gray, E. Weitz, Langmuir 19 (2003) 1402-1409.

[214] A.G. Agrios, K.A. Gray, E. Weitz, Langmuir 20 (2004) 5911-5917.

[215] S. Kim, W. Choi, J. Phys. Chem. B 109 (2005) 5143-5149.

[216] Y. Cho, H. Kyung, W. Choi, Appl. Catal. B Environ. 52 (2004) 23-32.

[217] C. Feldman, K. Moorjani, APL Tech. Dig. (1968) 2-9.

[218] Y. Liu, L. Tian, X. Tan, X. Li, X. Chen, Sci. Bull. 62 (2017) 431-441.

[219] M. Faraldos, A. Bahamonde, Catal. Today 285 (2017) 13-28.

[220] H. Wu, X.-L. Wu, Z.-M. Wang, H. Aoki, S. Kutsuna, K. Jimura, S. Hayashi, Appl.

Catal. B Environ. 207 (2017) 255-266.

[221] M. Maletić, M. Vukčević, A. Kalijadis, I. Janković-Častvan, A. Dapčević, Z.

Laušević, M. Laušević, Arab. J. Chem. (2016).

[222] Y. Li, M. Ma, S. Sun, W. Yan, Y. Ouyang, Appl. Surf. Sci. 254 (2008) 4154-4158.

[223] N. Baccile, G. Laurent, F. Babonneau, F. Fayon, M.M. Titirici, M. Antonietti, J.

Phys. Chem. C 113 (2009) 9644-9654.

[224] V. Vashchenko, L. Kutulya, A. Krivoshey, Synthesis-Stuttgart 14 (2007) 2125-2134.

[225] B. Manoj, A.G. Kunjomana, Int. J. Electrochem. Sci. 7 (2012) 3127-3134.

[226] E. Fuente, J.A. Menendez, M.A. Diez, D. Suarez, M.A. Montes-Moran, J. Phys.

Chem. B 107 (2003) 6350-6359.

[227] A.C.S. Talari, M.A.G. Martinez, Z. Movasaghi, S. Rehman, I.U. Rehman, Appl.

Spectrosc. Rev. 52 (2016) 456-506.

[228] C. Chen, X. Sun, X. Jiang, D. Niu, A. Yu, Z. Liu, J.G. Li, Nanoscale Res. Lett. 4 (2009) 971-976.

[229] X. Sun, Y. Li, Angew. Chem. Int. Ed. Engl. 43 (2004) 597-601.

[230] E. Fuente, J.A. Menéndez, M.A. Díez, D. Suárez, M.A. Montes-Morán, J. Phys.

Chem. B 107 (2003) 6350-6359.

[231] S.L. Iconaru, F. Ungureanu, A. Costescu, M. Costache, A. Dinischiotu, D. Predoi, J.

Nanomater. (2011). 
[232] C. Wang, B.L. Dou, Y.C. Song, H.S. Chen, M.J. Yang, Y.J. Xu, Energ. Fuel 28 (2014) 3793-3801.

[233] V.K.L. Mer, Ind. Eng. Chem. 44 (1952) 1270-1277.

[234] K. Vajda, Z. Kasa, A. Dombi, Z. Nemeth, G. Kovacs, V. Danciu, T. Radu, C. Ghica, L. Baia, K. Hernadi, Z. Pap, Nanoscale 7 (2015) 5776-5786.

[235] N.A. Nikonenko, D.K. Buslov, N.I. Sushko, R.G. Zhbankov, Biopolymers 57 (2000) 257-262.

[236] S. Karimi, J. Feizy, F. Mehrjo, M. Farrokhnia, RSC Adv. 6 (2016) 23085-23093. [237] A. Mahyar, A.R. Amani-Ghadim, Micro Nano Lett. 6 (2011) 244.

[238] N.T. Nolan, M.K. Seery, S.C. Pillai, J. Phys. Chem. C 113 (2009) 16151-16157. [239] L. Liu, J. Yang, S. Liu, L. Bai, B. Liu, Q. Wang, G. Xu, P. Jing, S. Yu, J. Zhang, Catal. Commun. 54 (2014) 66-71.

[240] S.J. Kalita, S. Qiu, S. Verma, Mater. Chem. Phys. 109 (2008) 392-398.

[241] P. Wang, L. Yang, L. Wang, J. Zhang, Mater. Lett. 164 (2016) 405-408.

[242] P. Berki, B. Reti, K. Terzi, I. Bountas, E. Horvath, D. Fejes, A. Magrez, C.

Tsakiroglu, L. Forró, K. Hernadi, Phys. Status Solidi B 251 (2014) 2384-2388.

[243] V. Maria Vinosel, M. Asisi Janifer, S. Anand, S. Pauline, Mech. Mater. Sci. Eng. (2017).

[244] Q. Hu, B. Liu, z. Zhang, M. Song, X. Zhao, Journal of Wuhan University of Technology-Mater. Sci. Ed. 25 (2010) 210-213.

[245] Z. Xu, M. Quintanilla, F. Vetrone, A.O. Govorov, M. Chaker, D. Ma, Adv. Funct. Mater. 25 (2015) 2950-2960.

[246] T.A. Egerton, J.A. Mattinson, J. Photochem. Photobiol. A Chem. 194 (2008) 283289.

[247] B. Sun, A.V. Vorontsov, P.G. Smirniotis, Langmuir 19 (2003) 3151-3156. 


\section{Acknowledgements}

I want to thank Prof. Zoltán Kónya that he made possible for me to carry out my research work in the Department of Applied and Environmental Chemistry.

I am indebted to Prof. Klára Hernádi that she offered me the opportunity to work in her research group, all her guidance, and that she has given me a free hand to proceed with my research into the direction which I deemed to have the most potential.

I am infinitely grateful to Dr. Gábor Veréb for his tremendous professional support and friendship starting from my BS.c. thesis until and beyond my Ph.D. thesis. I truly appreciated all his advice, professional or otherwise, and without doubt, I could not have got this far without his help.

I am very grateful to Dr. Zsolt Pap for his overwhelming support, professional advice, and that he always managed to point me in the right direction to resolve even to the most complex scientific problems.

I want to thank Dr. Balázs Réti all his assistance and insights regarding the topic of shape-controlled synthesis.

I want to give special thanks to my friends and colleagues from the research group, since they helped me enormously to get through all these years.

I am indebted to my family, friends, and fiancée, as without their support making this work would not have been possible.

Last but not least, I am grateful for the financial support of the following projects, making possible the operation of the lab, my attendance in conferences and my livelihood: NKFI-K-124212; GINOP-2.3.2-15-2016-00013; NKFI-TNN-16-123631; Campus Mundi scholarships (EFOP-3.4.2-VEKOP-15-2015-00001); Swiss Contribution (SH/7/2/20). 


\section{Appendix}

Appendix 1 IR spectra of carbon spheres purified with increasing amounts of acetone (CS_1 $<$ CS_2 $<$ CS_3, respectively) by membrane filtration.

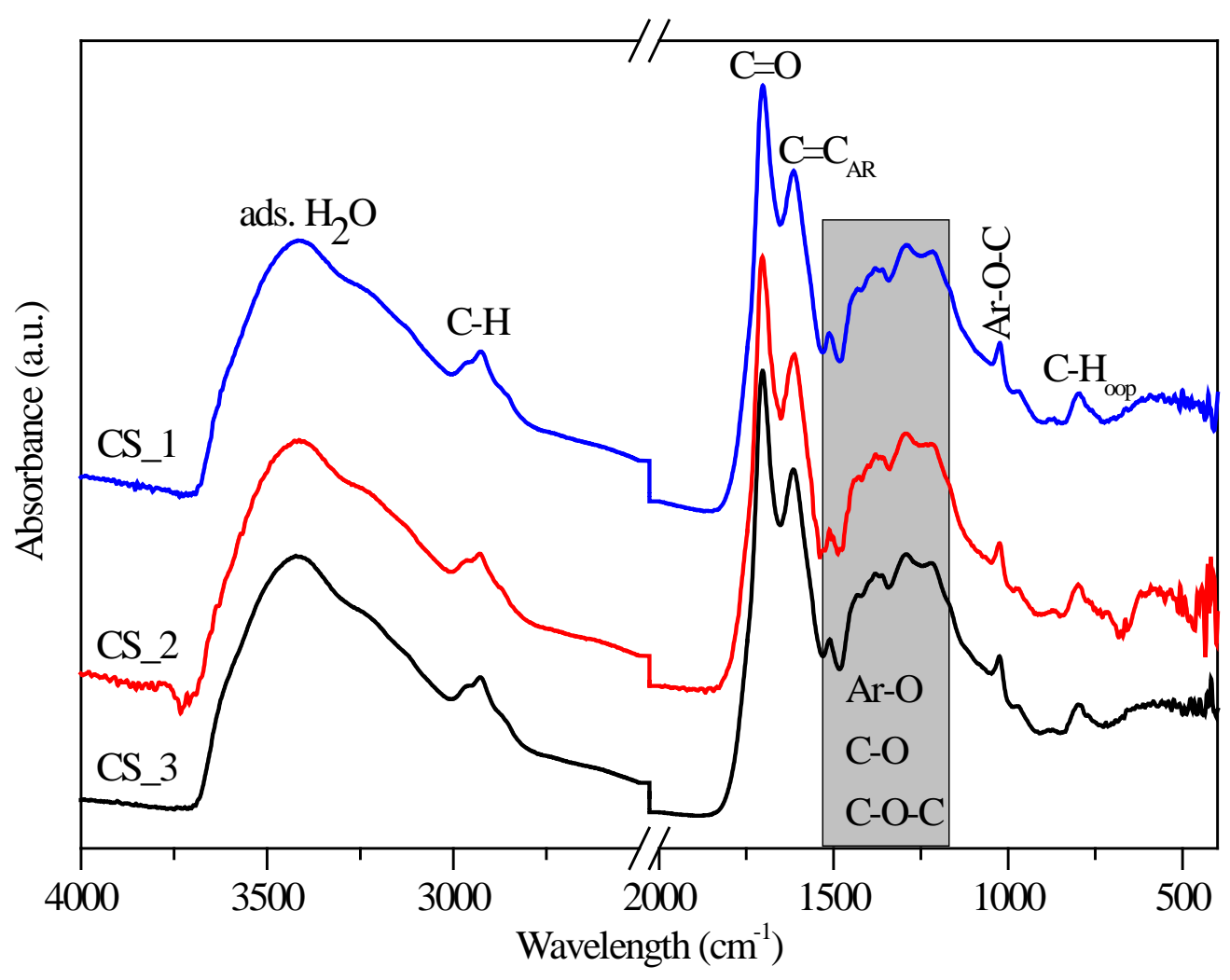


Appendix 2 Comparison of $\mathrm{TiO}_{2}-\mathrm{CS}$ composite and $\mathrm{TiO}_{2}-\mathrm{HS}$ via XRD (a), IR (b) measurements, phenol degradation (c) under visible light irradiation and SEM micrographs before (d) and after (e) calcination.
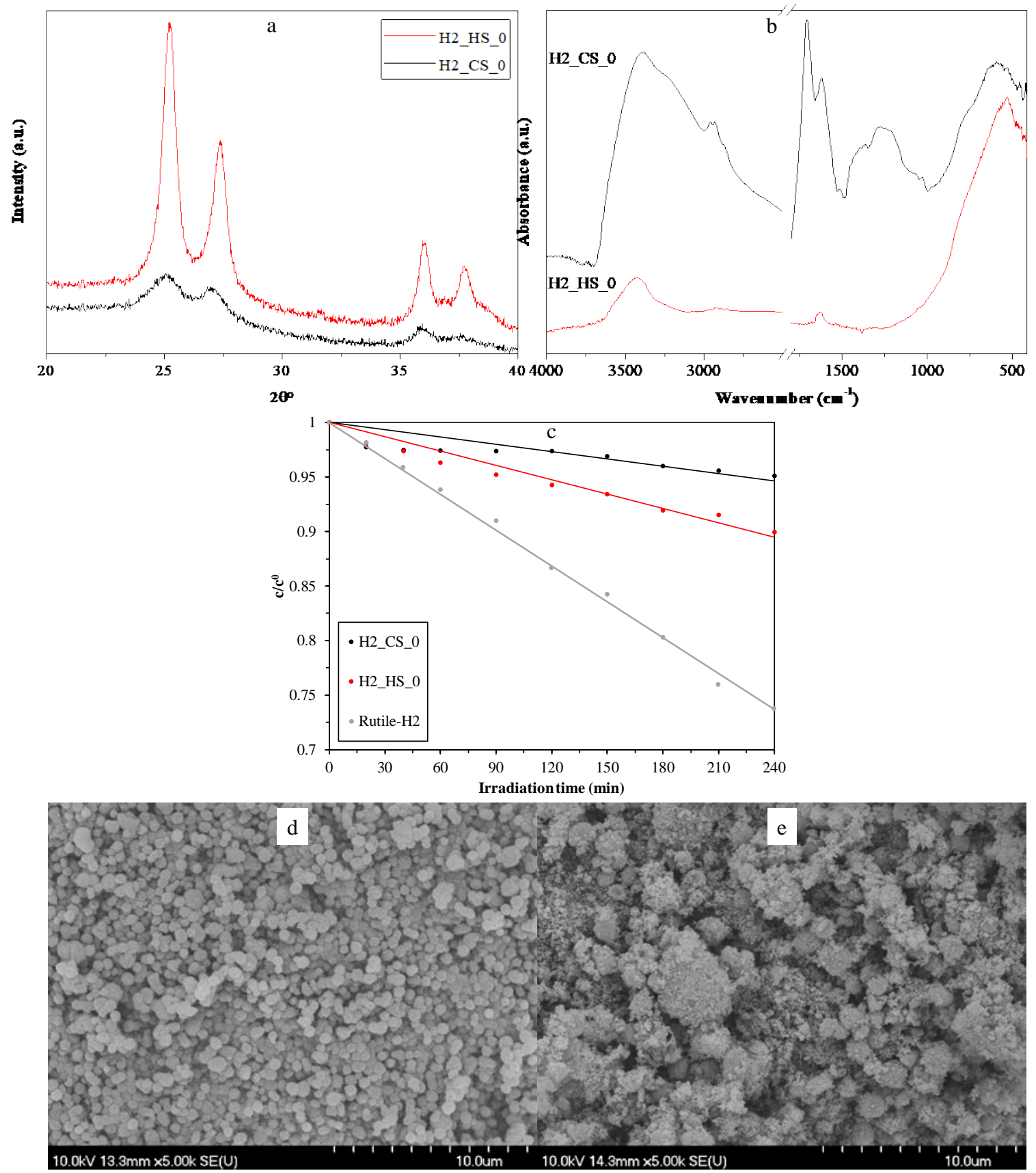
Appendix 3 SEM micrographs of samples H2_CS_1-4 and H2_HS_1-4.
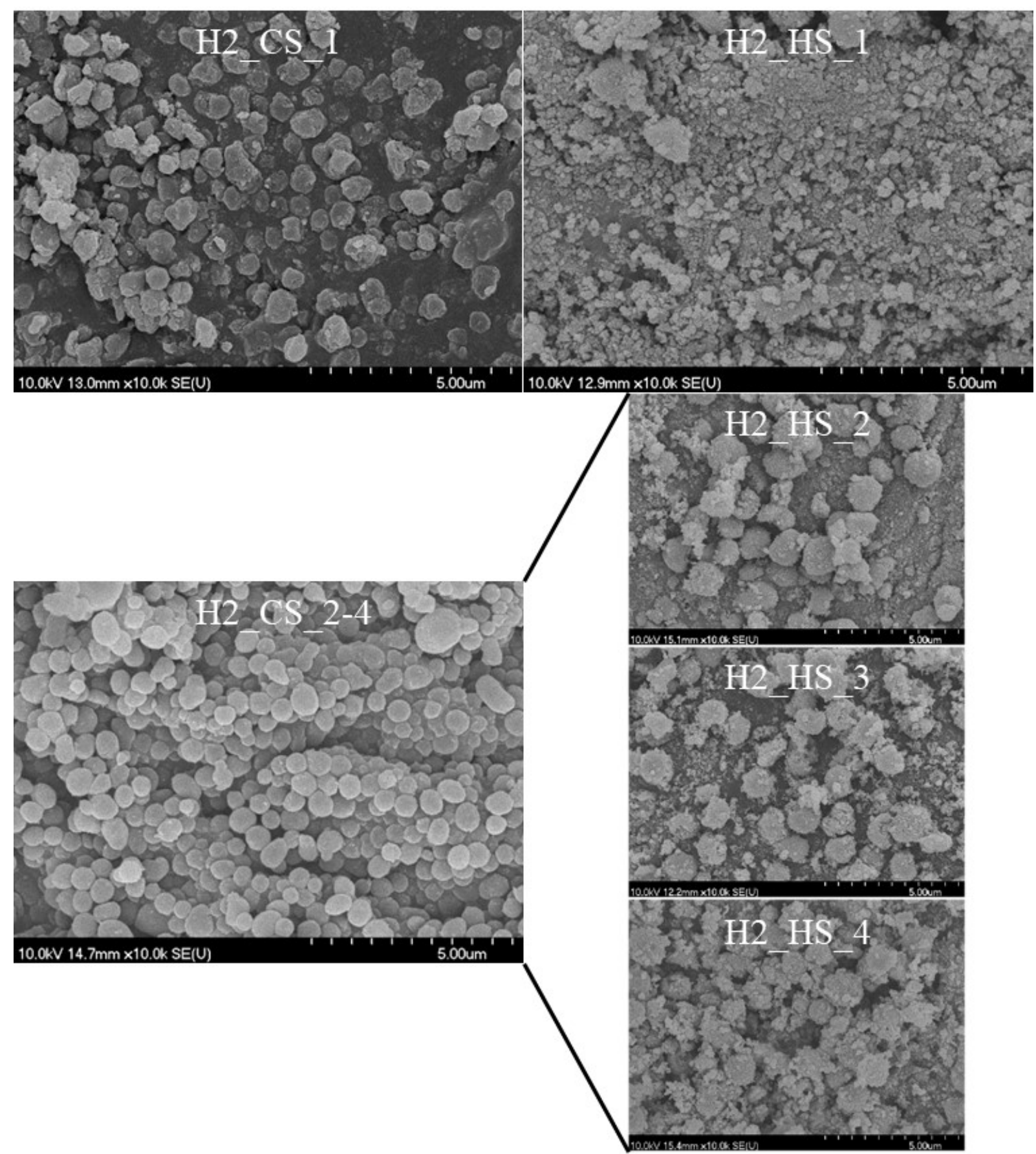
Appendix 4 XRD diffractograms of H2_HS_5 $\mathrm{TiO}_{2}$ before and after the 3 consecutive phenol degradation tests (a) and SEM micrographs of H2_HS_5 before (b) and after (c) the 3 consecutive phenol degradation tests (H2_HS_5_re).
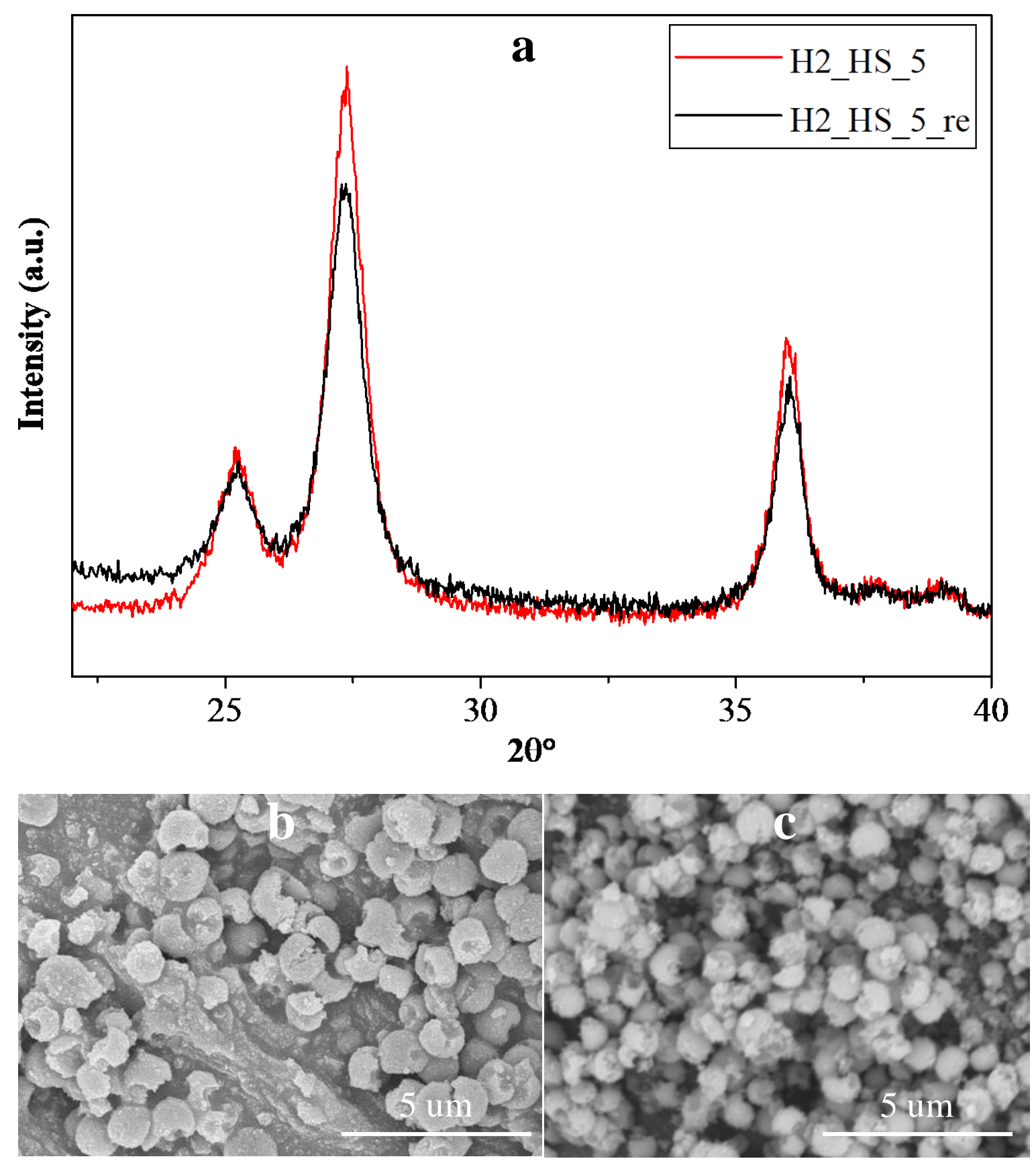
Appendix 5 Diameter size distributions of the $\mathrm{TiO}_{2}-\mathrm{HSs}$.
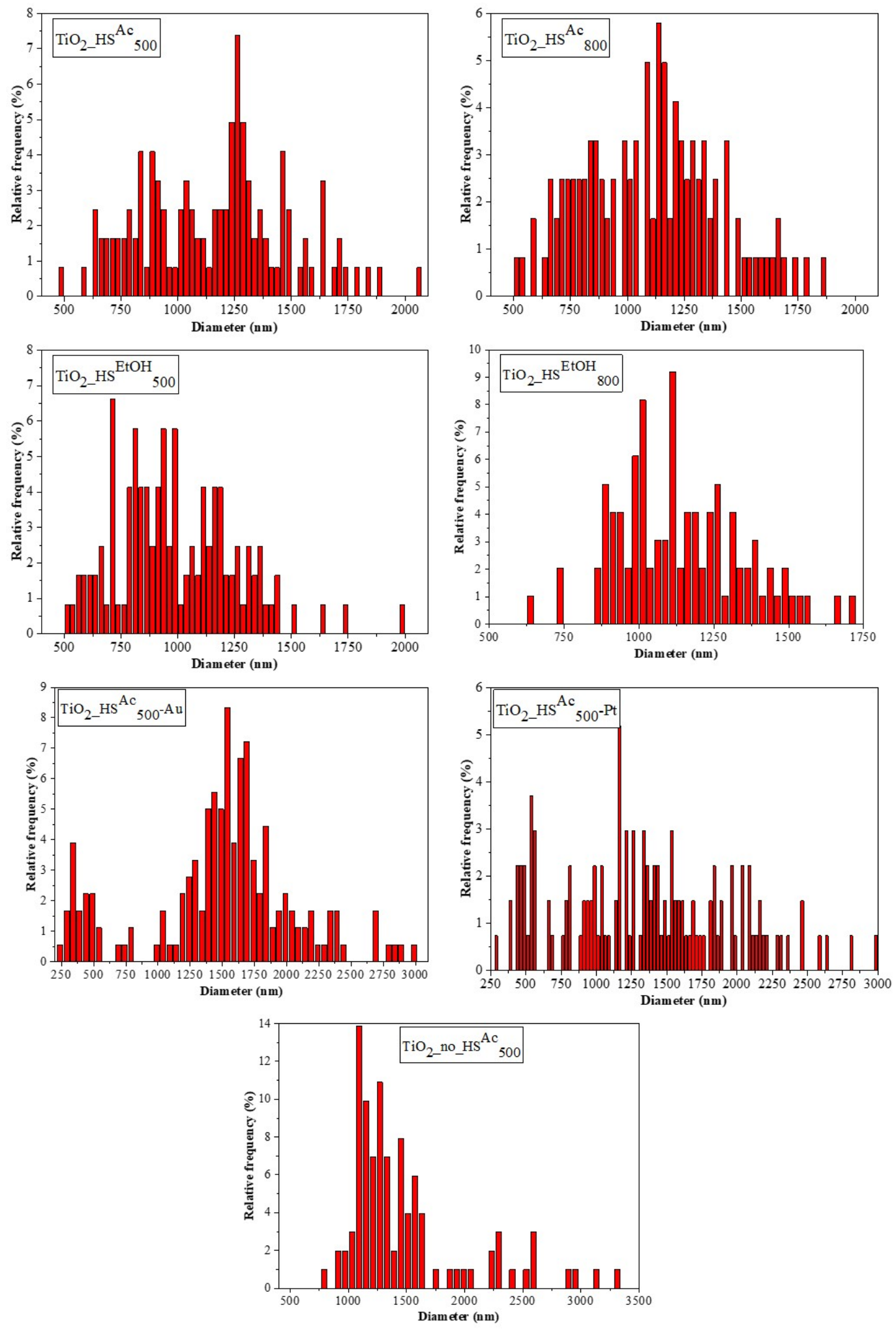
Appendix 6 Photocatalytic activity of the investigated photocatalysts under visible light irradiation $(\mathrm{t}=240 \mathrm{~min})$.

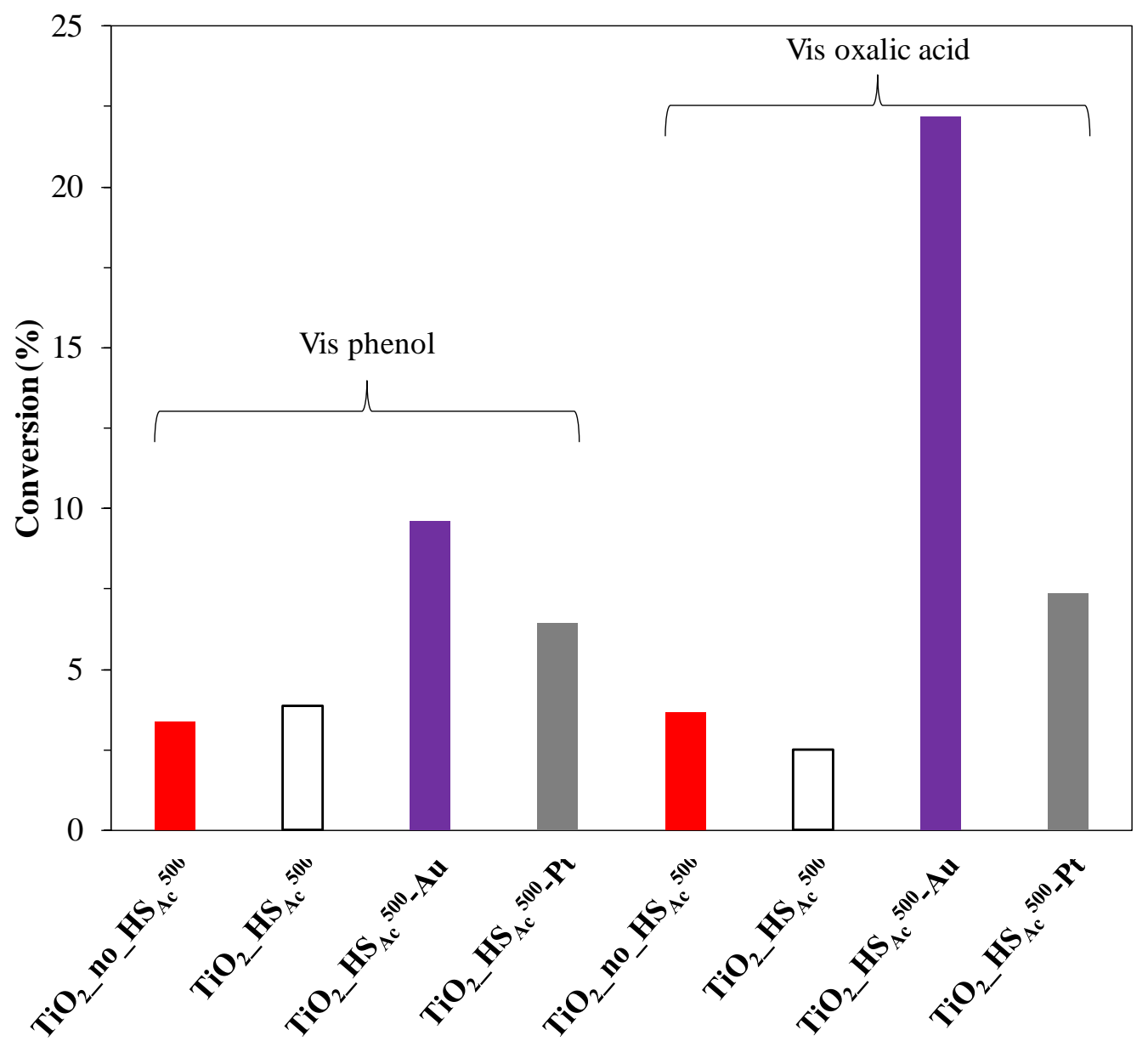

